



\section{The Next Big Thing?}

Trends Shaping Nordic Innovation

Jørn Bang Andersen, Senior adviser innovation

Nordic Innovation Center, Nordic Council of Ministers

\&

Patrick Crehan, Ph.D,

CEO Crehan, Kusano \& Associates

TemaNord 2009:546 


\section{The Next Big Thing?}

Trends Shaping Nordic Innovation

TemaNord 2009:546

(c) Nordic Council of Ministers, Copenhagen 2009

ISBN 978-92-893-1883-9

Print: Scanprint a/s, Århus

Copies: 500

The process and work of the publication under Iceland's chairmanship was supported and managed by Nordic Innovation Center.

Printed on environmentally friendly paper

This publication can be ordered on www.norden.org/order.

Other Nordic publications are available at www.norden.org/publications

Printed in Denmark

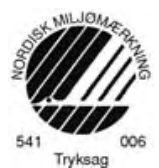

Nordic Council of Ministers

Store Strandstræde 18

DK-1255 Copenhagen K

Phone (+45) 33960200

Fax (+45) 33960202

\section{Nordic Council}

Store Strandstræde 18

DK-1255 Copenhagen K

Phone (+45) 33960400

Fax (+45) 33111870

\section{www.norden.org}

\section{Nordic co-operation}

Nordic cooperation is one of the world's most extensive forms of regional collaboration, involving Denmark, Finland, Iceland, Norway, Sweden, and three autonomous areas: the Faroe Islands, Greenland, and Åland.

Nordic cooperation has firm traditions in politics, the economy, and culture. It plays an important role in European and international collaboration, and aims at creating a strong Nordic community in a strong Europe.

Nordic cooperation seeks to safeguard Nordic and regional interests and principles in the global community. Common Nordic values help the region solidify its position as one of the world's most innovative and competitive. 



\section{Content}

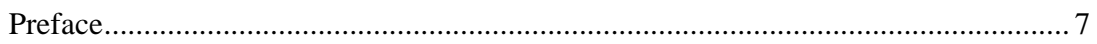

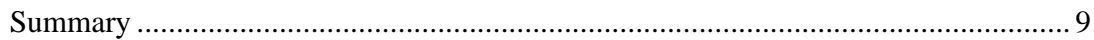

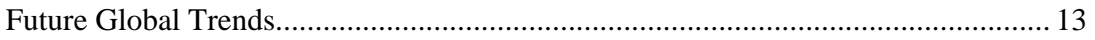

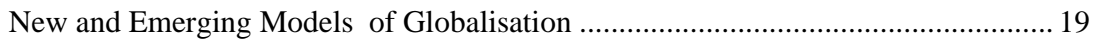

Leverage of Innovation Hot-Spots ...................................................................... 27

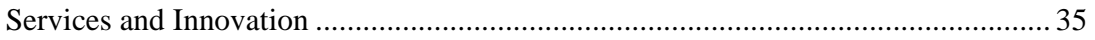

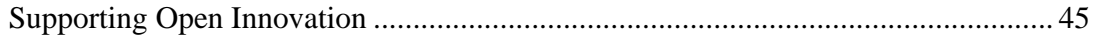

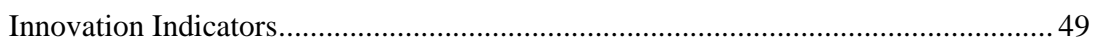

The Value Chain as the Innovation System........................................................... 55

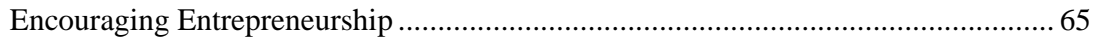

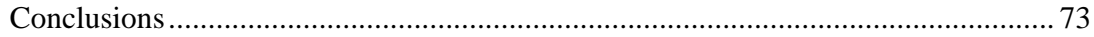

Special Focus: Climate Change - Impacts for Nordic Industry, Technology, and

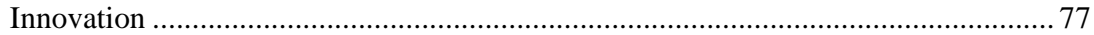

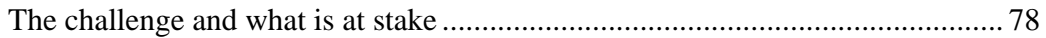

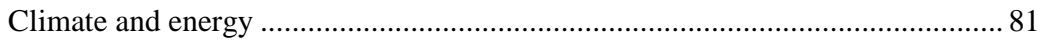

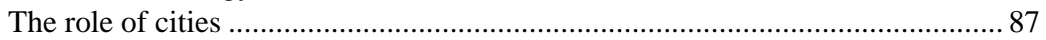

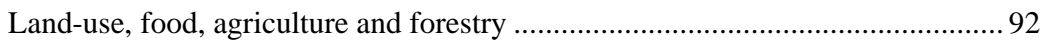

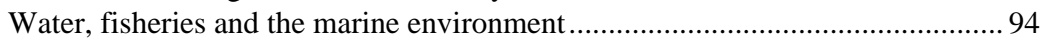

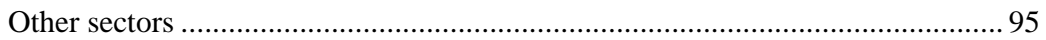

The specific challenge of climate-related innovation ........................................ 100

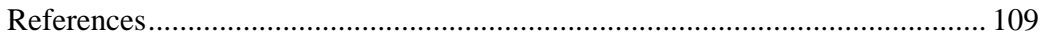

References related to the "Climate" chapter, in chronological order ................. 110

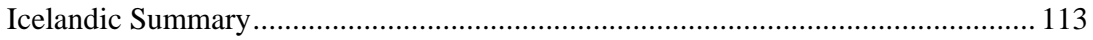

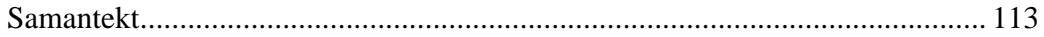

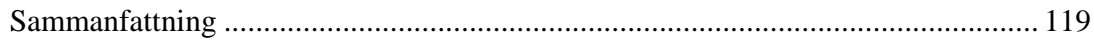





\section{Preface}

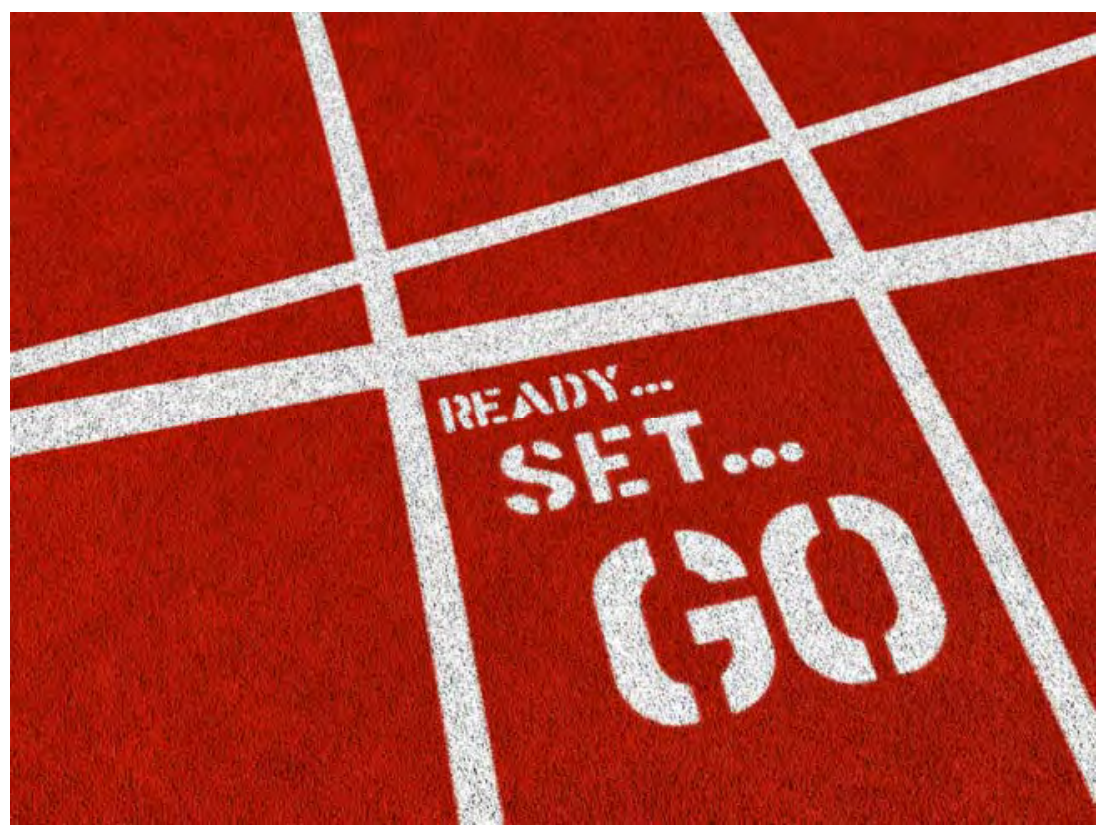


In 2004, the Nordic Council of Ministers launched its first White Paper on Nordic Innovation Policies and priorities. The White Paper instituted the first generation of innovation policies at the level of theNordic Council of Ministers. Since then, the world economy has experienced both one of its biggest upturns and subsequently one of its biggest downturns since the major recession of 1929. The global financial crisis and subsequent spillover into the real economy has radically turned the tables on a long list of performance indicators related to innovation and competitiveness all over the world. This has also been the case in the Nordic countries. They have all experienced the consequences of the global recession, where weaknesses have been exposed both among their financial and other important institutions linked to economic development. The challenge for the Nordic countries is to strike a sound balance between solving current problems and future needs for action. It might be prudent for the Nordic countries to view the current crisis as an opportunity to promote innovative concepts which will undoubtedly provide the basis for the future growth and prosperity of our societies. One should not forget Schumpeter's notion of "creative destruction" as the greatest force for innovation and competitiveness. One should also keep in mind that, as small open economies, the Nordic countries have gained considerable benefit from globalisation and the opportunities it has provided for trading, knowledge sourcing and innovation management tools such as open innovation. So what is this publication about? It will address some of the trends that will almost certainly have a major influence on the development of the Nordic countries in the coming years, and which will become significant driving forces for innovation and future change.

Icelandic Chairmanship

Nordic Council of Ministers 2009 


\section{Summary}

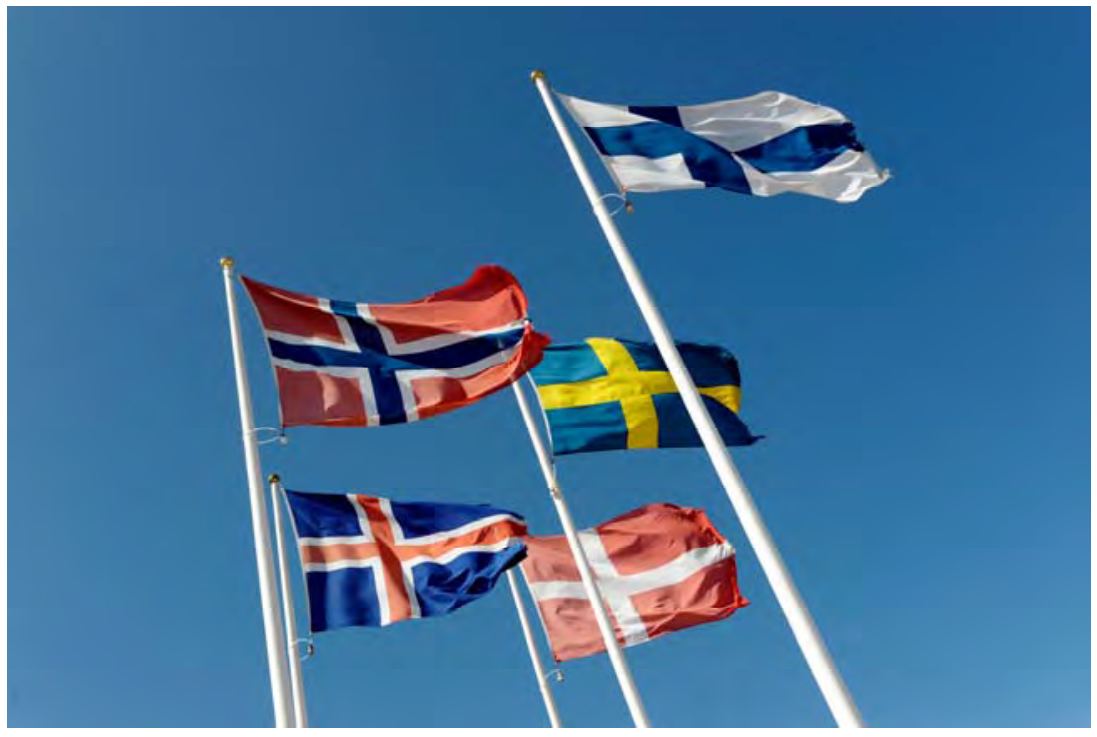


Regions, nations and companies that are able to change and adapt to new cirumstances will over time have the best chances of sustaining a healthy balance between growth and prosperity within their communities. It can by no means be taken for granted that the Nordic countries will be among the richest societies in the world. However, since the breakthrough of industrial and modern times the Nordic countries have shown themselves to be particularly capable of steady development and renewal. Cooperation between industry, government, academia and society as a whole has been one of the defining characteristics of the Nordic countries' development in these areas. Nordic co-opereation is in this sense a natural ingredient of the Nordic approach to development.

In 2005 the Nordic Council of Ministers formulated a common Nordic innovation policy. The aim was to consolidate innovation within each of the Nordic countries, and in the region as a whole, including the Baltic countries and neighbouring regions. The intention of the Icelandic chairmanship and this publication is to point out future trends that are likely to shape the discussion on innovation, and to exert an influence on the Nordic countries' innovation policies and priorities.

This publication focuses on future trends which are likely to have an impact on the next generation of Nordic innovation policy. Thematically the chapters deal with the concepts of:

- The Transition to a Sustainable Economy

- New and Emerging Models of Globalisation

- The Value Chain as the Innovation System

- The Role of Organisation and Management

- Measuring and Managing Innovation

- The Confusion between Research and Innovation

- Leveraging Global Innovation Hot-spots

Without going into detail about the content of each chapter in this summary, these concepts influence the Nordic Council of Minister's globalisation initiatives in various ways. They also highlight future challenges and key issues linked to Nordic innovation policies. As mentioned above, the Nordic economies have historically been successful in adapting to changing circumstances and in the application innovative solutions. However, in order to sustain this development the Nordic region will probably have to 
assume a leadership role, and not simply be a follower in many of the areas discussed under future trends. There are signs that this is already happening. For example, within innovation in the public sector and other areas, such as developing solutions for tapping into global innovation hot spots.

Nevertheless, two issues in particular have changed the way in which we can best approach and discuss the future role of the Nordic countries. These are global warming and the global financial meltdown. The global financial meltdown has shown us that the last 25 years of economic policies have failed in some important areas. A possible outcome of this is that we will have to rethink our role in the global economy, reassess how we access resources and, not least, how we utilise these resources. The second issue is global warming. This may be viewed either as an opportunity or a constraint. It can be seen as an opportunity in the sense that the Nordic region possesses a strong platform for the development of new solutions and jobs within existing and emerging areas linked to energy and the environment. However, in order to succeed, the Nordic region will probably have to to re-evaluate central elements of the existing growth model, and thereafter also our perception of innovation. The departure from a fossil fuel based to an environmentally sustainable economy will require new forms of organisation, new means of global collaboration, new incentives for entrepreneurs, and new methods of statemarket interaction.

In fact, the notion of an innovation economy might already be outdated. A more appropriate term might be the "wisdom economy". This is an economy not soley based on the growth paradigm of the industrial and contemporary era, but rather on a debate related to how quality can be measured in other terms than financial gain, and within the ramifications of global warming and financial constraints. 



\section{Future Global Trends}

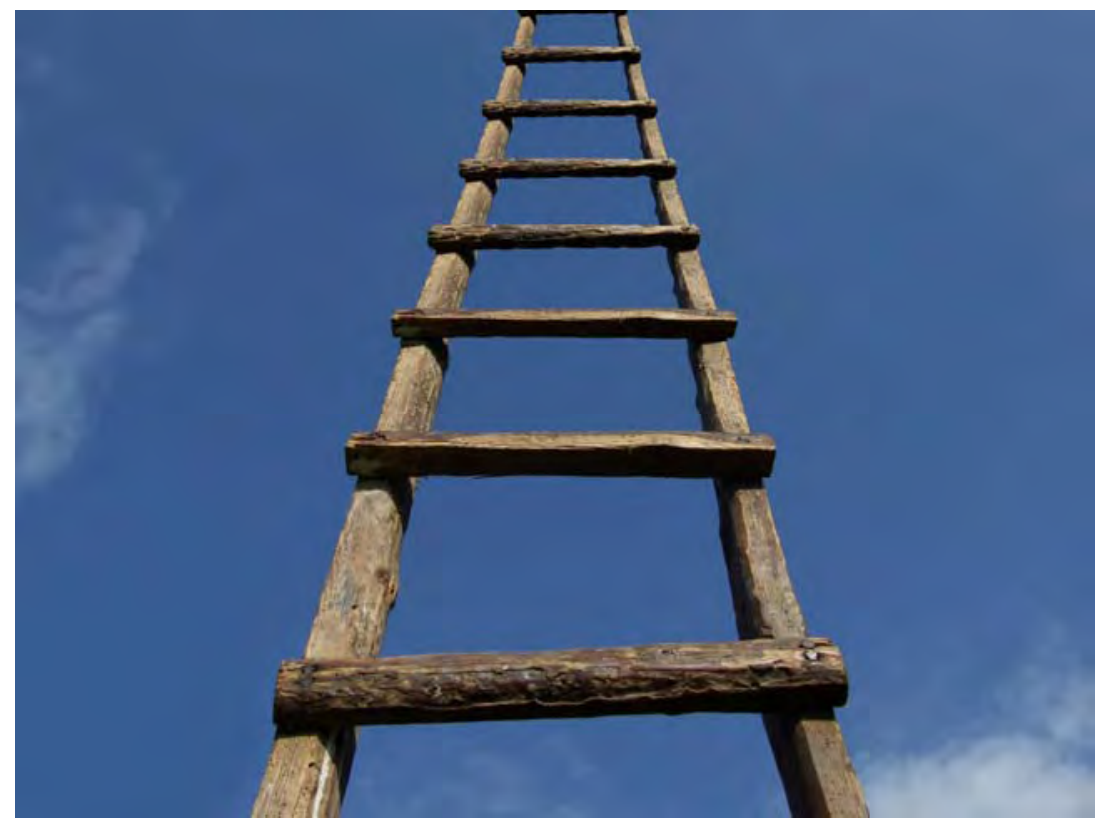


The Nordic economic block constitutes one of the world's most innovative and affluent regions. In order to sustain this lead, it is not sufficient for Nordic countries simply to follow trends. They must also set the trends. Many new and arguably pressing issues have arisen in innovation debates around the world during the last few years. These ideas represent a departure from traditional thinking and thus deserve further consideration. NICe could play a role in this context by means of its innovation research and pilot programs. The issues listed below are discussed in more detail in the following chapters:

- The Transition to a Sustainable Economy

- New and Emerging Models of Globalisation

- The Value Chain as the Innovation System

- The Role of Organisation and Management

- Measuring and Managing Innovation

- The Confusion between Research and Innovation

- Leveraging Global Innovation Hot-spots

The Transition to a Sustainable Economy: During most periods of economic history it has never been entirely clear where the next "new idea" will come from or how important such an idea is likely to be. Nordic, European and even global policy trends indicate that issues such as carbon markets, climate change, renewable energy and industrial feedstock, recycling and the efficient use of energy, water and other natural resources, will all assume considerable importance in the years to come. These sectors are essential components of an emerging sustainable economy. This global transition will affect not only existing companies and start-ups, but also the entire value chains to which they belong. This requires innovation at system level and on an unprecedented scale. If change is to be achieved on a sufficiently large scale to meet national and international energy, climate and security goals, policies may need to focus more on issues such as the sourcing and adoption of new technologies. .

New and Emerging Models of Globalisation: Perhaps the most established model of globalisation is that based on access to external natural resources. This gave way to a model based on access to external markets. A more recent model is based on access to external knowledge. Knowledge, and in particular high-level scientific and technical knowledge, is 
obviously a global commodity. The last 10 years has seen a major shift in terms of how large innovative companies meet their research needs. Outsourcing and offshoring, combined with the mediated sourcing of scientific and technical services, are now well established components of this trend. In recent years, two further globalisation models seem to have emerged which may deserve greater attention from policy makers and innovation researchers ${ }^{1}$. The first deals with the markets of emerging economies. These may be much more promising than appear at first sight, and pose unique innovation challenges for the companies and entrepreneurs that are interested in the opportunities they provide.

The second deals with a trend towards the global acquisition of external land via lease or outright purchase, by governments, private companies and groups of individual entrepreneurs. This is linked to the export of production systems, as well as management and organisational knowhow. In the past, some Nordic countries have had considerable success with this last model, and it could become a promising focus for innovation-related initiatives in the future.

The Value Chain as the Innovation System: For the last 15 or 20 years innovation researchers and policy makers have adopted the habit of analysing innovation systems and of thinking about them from the point of view of the public sector institutions which are intended to support them. Whatever the original motivation for doing this, the approach resembles studying a disease only by examining the doctors that treat it. Innovation is about business. It is "done” by companies. It is a risky, collaborative, iterative, self-correcting activity that spans entire value chains, not individual companies, research labs or university departments.

And yet the innovation research environment seems almost oblivious to this fact. A lot of work has been carried out on developing innovation policies, but relatively little on how innovation actually occurs, and how the practice of innovation evolves. A survey of the literature on innovation gives the distinct impression that the key players are not the companies and their supply chains, but universities and national research institutes. It is true that these institutions have a role to play but such has to be seen in context. Large innovative companies such as IBM or Intel collaborate with between 500 and 1,000 universities and research labs lo-

\footnotetext{
${ }^{1}$ These are fully addressed in a forthcoming paper by NICe on Global Innovation-Related Trends.
} 
cated in most of the countries of the world. Merck carries out almost 12\% of all research in the domains of interest to its business - possibly more than any single country. Companies are responsible for two-thirds of the research carried out in the world and run corporate universities involving up to half a million people. These include their own staff together with those of their supply chain partners and small research teams dispersed among their hundreds of knowledge partners. They organise and manage their own innovation agenda in large, complex dynamic networks. Companies such as Wal-Mart, P\&G and Intel play an active role in the development of innovation and entrepreneurship both among their supply chain partners and in collaboration with SMEs operating in their sectors of interest. They promote robust market intelligence and orientation, access to tools and finance, support for marketing and distribution as well as business service brokerage. These companies embody a wide range of models and philosophies for innovation support. Such models have so far received scant attention from innovation researchers. They can teach us a lot about the management and organisation of innovation and should perhaps receive more attention in the future.

The Role of Organisation and Management: Venture capitalists insist that when they invest in a company, they invest primarily in people, and not ideas. They examine the management and the market, together with the possibility of the venture establishing a defensible position in that market. They rarely look for technologies. On the other hand, large or well established companies are always looking for new technologies. The innovation game is different for them. They already have excellent managers, a profound knowledge of markets and their future needs as well as excellent distribution systems.

To them, technology or know-how is just another input variable, and they are always on the lookout for technologies that meet specific needs. The lesson here is that it is management that matters first and foremost. A recent survey of Fortune 500 companies in the US ${ }^{2}$ revealed that only 6\% of CEOs thought that their position of excellence as a company was the result of a great idea. Almost all beleived that it came from excellence in execution. This boils down to processes, organisation and management. Managers are the ones who make decisions, assign resources and develop human capital. Management matters! Yet, in the past, management and

\footnotetext{
${ }^{2}$ Reported by Amar Bhidé in his highly acclaimed book "The Venturesome Economy”.
} 
management innovation has received almost no attention from innovation policy makers and researchers. Perhaps future research and policy interventions should try to fill this gap.

Measuring and Managing Innovation: There is growing dissatisfaction with current approaches to measuring innovation at national level. This is an important issue because measurement is an essential component of modern scientific management. The US, the UK and organisations such as the OECD are all re-evaluating their approach to measuring innovation at national level. The NICe-financed NordTrend project is examining these issues and has recently piloted new approaches based not on the measurement of input variables such as research, but on the profiling of innovation-related company capabilities. The findings are instructive and the project raises many issues linked to possible new approaches to measuring innovation. Some of these may be worth following up as part of future innovation research and pilot projects supported by NICe.

The Confusion between Research and Innovation: There appears to be an increasing need to emphasise that research is not the same as innovation. This is especially true of research in engineering and the natural sciences. Research is one of many input variables to innovation, along with high quality management, distribution and marketing, suitably structured financing, receptive markets, venturesome consumers, work-culture and practices as well as human resource policies. It is possible that innovation policies do not as yet adequately take this into consideration. A recent authority on innovation claims that it is possible to over-invest in research. The reason is that doing so could divert resources from other tasks essential to innovation such as marketing, sales and management. All of these processes require creativity and invention and it is the contributions from highly talented individuals who bring leadership to their roles in marketing and distribution that are essential if the potential created by the knowledge inherent in disciplines related to science, technology and engineering is to be realised. In the Nordic countries we speak of the Norwegian and Swedish paradoxes. To really understand what is going on we need to distinguish properly between research and innovation as activities, and to address research in its proper context. It also means that we need to broaden our outlook in terms of how science can contribute to the overall innovation process. To do so we need to distinguish between "science" and "the scientific method". Companies such as 
IBM are trying to make a science of "service". Business and management gurus such as Gary Hammel continue to emphasise the role of innovation in management itself, and of research in management involving the investigation of the practice of management using "management laboratories". Writers such as Christopher Hill believe that we are now moving into a "post-scientific" society where disciplines such as the humanities and the arts will make a more significant contribution than before. Progress will only be made if we first of all understand what innovation really is and remove the prevailing confusion with research. The NICe financed InnoTools project is a step in this direction, and future additional and similar activities could be of use to industry and provide important insights for innovation policy makers in future. 
New and Emerging Models of Globalisation

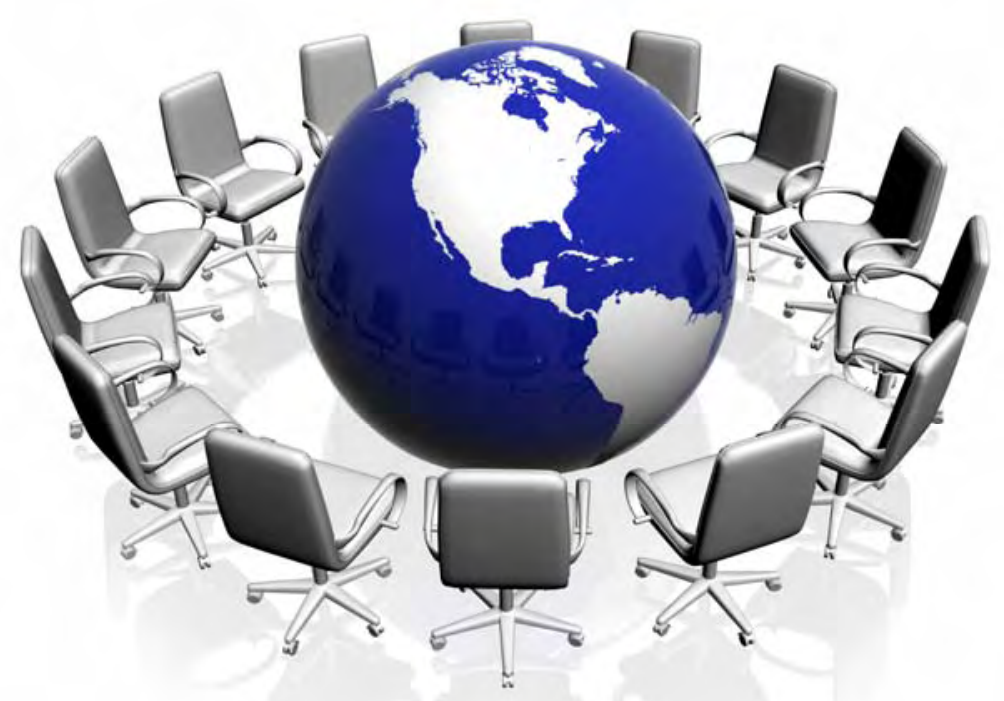


Perhaps the most etsablished model of globalisation was that based on access to external natural resources. This gave way to a model based on trade access to external markets. It is possible to see this model being played out today in situations such as where the main participants are the so-called BRIC countries using both each other and the poorer resourcerich countries of Africa, Eastern Europe and Latin America as targets Recent reports suggest that a entirely new development dynamic is emerging involving China and the Middle East. Chinese manufacturers whose sales to the US collapsed as a result of the financial crisis are now searching for new markets in the Middle East. In early 2009 China overtook the United States as the world's largest exporter to the Middle East. Each year the Middle East now purchases $\$ 58$ billion worth of goods and materials from China. Much of this growth is the result of the entrepreneurial efforts of small Arab traders venturing on their own to cities such as Yiwu, which is located about a four hour drive south of Shanghai. This city receives about 200,000 Arab visitors annually. It has over a dozen Arabic restaurants on its main street. This only began in $2001^{3}$. Ben Simpenfendorfer ${ }^{4}$ relates how in the case of one textile manufacturer in the coastal province of Zhejiang, the Middle East now accounts for $20 \%$ of his exports. The exporter now plans to set up a branch office in Dubai. As production costs in China rise, others are scouting for manufacturing locations in the Middle East. Egypt, with its low-cost workforce, is a particularly attractive investment destination.

A more recent model is based on access to external knowledge. Knowledge, especially high-level scientific and technical knowledge, is a global commodity. The last 10 years has seen a significant shift in terms of how large innovative companies meet their research needs. Outsourcing and offshoring, combined with the mediated sourcing of scientific and technical services are now well established components of this trend. In recent years, the "open innovation" practices of major companies have received considerable attention from managers and innovation researchers. It is natural that the quest for knowledge relevant to the innovation and business development needs of companies is globally oriented, and most Nordic countries have independently established international inno-

\footnotetext{
${ }^{3}$ Newsletter of the MEC Analytical Group, 17 May 2009, China and the Middle East market

4 "The New Silk Road: How a rising Arab world is turning away from the west and rediscovering China” by Ben Simpfendorfer, published by Palgrave Macmillan in 2009.
} 
vation infrastructures intended to provide access to the global knowledge and to support innovative companies in their ventures abroad. This issue has been discussed in some detail in the NICe report entitled "The Establishment of Nordic Innovation Representations in Asia?" 5 The report discusses the concept of a jointly operated system of international innovation centres that would complement existing national systems and thus explore the opportunities provided by new and emerging markets and their associated hot-spots linked to research, innovation or emerging market opportunities.

Recently, there has been progress in the development of EU accession countries as well in those North African countries neighbouring the EU. These countries have made significant progress in developing structures, policies and practices linked to FDI. This has been true in particular of Morocco, Tunisia and, more recently, Syria. FDI has played a very important role in their emergence as global trading partners, and these countries have become serious FDI targets for multinational firms investing in areas such as micro-electronics, energy, tourism, telecommunications, construction, retail, business services, aeronautical engineering and pharmaceutics. It is possible that these low to middle income countries, which have largely been ignored by the Nordic countries, may be worthy of closer scrutiny in the future.

This is now a good time to examine two more globalisation models that have emerged in recent years, and which may deserve greater attention from policy makers and innovation researchers ${ }^{6}$ in the near future.

The first of these new models deals with the markets of emerging economies, which may be considerably more promising than appears at first sight. They pose unique innovation challenges for the companies and entrepreneurs interested in the opportunities they offer.

Since 2006 the management guru C. K. Prahalad has written about "the Fortune at the Bottom of the Pyramid"7. He uses examples to illustrate how market opportunities exist in the poorest economies not just in emerging markets, but also in areas such as finance, health care, energy, communications, construction, agriculture and household goods. In 2007

\footnotetext{
${ }^{5}$ http://www.nordicinnovation.net/prosjekt.cfm?id=3-4415-291

${ }^{6}$ These are fully addressed in a forthcoming paper by NICe on Global Innovation Related Trends.

7 "The Fortune at the Bottom of the Pyramid: Eradicating Poverty Through Profits" by C. K. Prahalad, published in 2006 by Wharton School Publishing Paperbacks, ISBN 978-0131877290
} 
The World Resources Institute ${ }^{8}$ published a study of the global $\mathrm{BOP}^{9}$ markets entitled "The Next 4 Billion" ${ }^{10}$. The report is based on household surveys carried out in 110 countries. It segments BOP markets in Africa, Asia, Eastern Europe, Latin America and the Caribbean on the basis of rural and urban households and their annual incomes. It provides estimates of their spending capacities related to essentials such as food, water, ICT, health care, transport, housing and energy. The study estimates that these correspond to annual markets worth $\$ 5 \mathrm{~T}$, in which consumers have largely unmet needs and in which they are penalised by overpaying for existing solutions. For example, in Mexico they show that the BOP consumer category corresponds to $75 \%$ of the population, that they are concentrated in higher earning segments and have an aggregated annual income of \$155B.

Major international companies such as P\&G, Unilever, Kraft and Nestlé have examined the issue of consumer goods. Cargill has addressed issues relating to logistics. Ericsson is leading important initiatives in Africa, as is Nokia in India. Nicolas Negroponte championed efforts to create a \$100 laptop. There are projects to develop the \$10 mobile phone and the $\$ 1000$ car. Microsoft Corporation has launched its Unlimited Potential Program ${ }^{11}$ with a commitment to bring the benefits of relevant, accessible and affordable software to 5 billion more people, combined with a goal of reaching the first 1 billion by 2015 . Are such activities only the domain of large companies? Or do small- and medium-sized companies have a role as well? Much more remains to be done.

"Portfolios of the Poor"12 goes even further than "The Fortune at the Bottom of the Pyramid". It looks closely at how people who live on less than $\$ 2$ a day - about $40 \%$ of the world population - manage their money. This study finds that such people often employ sophisticated techniques to get the most out of what they have; they actively budget, save, access credit and manage risk on the basis of extensive social networks usually involving family and friends. It provides deeper insights

\footnotetext{
${ }^{8}$ www.wri.org

${ }^{9}$ BOP is Shorthand for "Bottom of the Pyramid"

10 "The Next 4 Billion - market size and business strategy at the base of the pyramid" ISBN: 1-56973-625-1 available for free online at www.wri.org.

${ }^{11} \mathrm{http} / / / \mathrm{www} . s i d w . o r g / e v e n t / 2007 /$ unlimited-potential-connecting-the-next-five-billion

${ }^{12}$ By Daryl Collins, Jonathan Morduch, Stuart Rutherford and Orlanda Ruthven, published in 2009 by Princeton University Press, ISBN 978-0-691-14148-0
} 
into the financial context in which these people run their lives, enabling the authors to re-examine existing systems of micro-credit, to suggest improvements, and to identify new market and business opportunities.

Many are familiar with the story of Mohamed Yunus, the Grameen Fund and the invention of micro-finance ${ }^{13}$. This has helped many people and has led to the creation of a new kind of banking industry that has spread rapidly, especially in the developing world. It has brought access to finance to an entirely new generation of people who are otherwise lacking in collateral, and has made an important contribution to progress in many developing economies. The story of micro-finance is not without controversy but it is an evolving sector and it will be some time before the last word on the subject is written. It demonstrates that innovation in finance, consumer credit, and business lending is possible even in the poorest economies.

Jacqueline Novogratz, as CEO of the Acumen Fund, has developed a new approach to investing in emerging economies. Her recent book ${ }^{14}$ explains the current challenges facing the philanthropic community and the opportunity as she sees it to move from the traditional public sector approach to development aid. Her approach is to employ what she calls "patient capital" in order to help entrepreneurs bring in management and organisational skills to realise projects providing essential commodities such as food, water, health care or affordable housing. The Acumen fund evaluates projects on the basis of leadership, economic sustainability and scalability. Scalability comes down to whether or not the enterprise can reach at least a million customers, thus providing a model that she can apply on a global scale.

The central argument is that there is an alternative to aid of the kind advocated by rock stars such as Bono of U2, and experts in poverty such as Jeffrey Sachs. Whereas charity and disaster relief have an important role to play in the world, writers such as Prahalad and entrepreneurs such as Mohamed Yunus and Jacqueline Novogratz make the point that business and trade represent the only sustainable means of improving the lot

13 "Banker to the Poor : Micro-Lending and the Battle Against World Poverty" is an autobiography of Mohamed Yunus, the founder of Grameen Bank and inventor of micro-finance, published in revised and updated form in 2003 by Public Affairs, ISBN 978-1586481988.

14 "The Blue Sweater - bridging the gap between rich and poor in an interconnected world" by Jacqueline Novogratz published in 2009 by Rodale, ISBN 978-1594869150. 
of the world's poor. Dambisa Moyo ${ }^{15}$, a former Goldman Sachs economist, claims in her recent and widely acclaimed book "Dead Aid", that aid to Africa has largely been a waste and has contributed to exacerbating the problems of corruption, low saving and even local business development. She points out that non-aid policies have worked for the BRICS, and especially for India and China, which 20 years ago were much poorer than most African nations. She points to South Africa and Mozambique as examples of countries in Africa where this approach is working. She effectively challenges donor countries to change from a trade rather than an aid approach to development, at the same time reminding us that $60 \%$ of the population of Africa is under the age of 24.

Business success in these unfamiliar and challenging environments will require innovation on the basis of an ability to strip issues down to their essentials, and to simplify complex, over-engineered products intended for advanced markets with high spending power. This will provide reasonably priced, simply recyclable and easily maintained products that meet the unfulfilled needs of the local population. Success will require innovation not only in terms of adapting products and services in this way, but also in terms of organisation and business model design, sourcing and local manufacturing, pricing, packaging, payment, branding and distribution. It will require a total innovation approach.

The second new globalisation trend involves the global acquisition of external land via lease or outright purchase, by governments, private companies and groups of individual entrepreneurs. The Economist magazine has recently referred to this phenomenon as "Outsourcing's Third Wave", noting that in the last two years alone over 2 million hectares of external farmland has been bought up or leased by foreign governments and well-connected private businesses, for a value of between \$20-30B. This practice is not new but the scale of recent activity is unprecedented and has caused alarm among international organisations such as IFPRI (the International Food Policy Research Institute). Despite the controversy this is a trend that could result in real benefits for both the Nordic countries and those to which they export their production know-how. The trend may be worth investigating with a view to projects funded by the program administered by the Nordic Innovation Centre.

\footnotetext{
15 "Dead Aid - why aid is not working and how there is another way for Africa" by Dambisa Moyo, published in 2009 by Penguin Books, ISBN 978-1-846-14006-8.
} 
Some Nordic countries have had considerable success organising agricultural production abroad. One of the most important examples is Denmark's extraordinary ability to export pork production systems incorporationg all of the associated management and organisational know-how.

In an address given at the World Agricultural Forum ${ }^{16}$ in May 2009, Prof. Paul Collier, author of "The Bottom Billion"17, explained that the involvement of the bottom billion in world trade was important for promoting the capability of the world to feed itself. He also stated that largescale industrial agricultural practices would play a critical role, combined with systems for transport and logistics, quality and productivity improvement. He is of the opinion that peasant agriculture on its own is not enough, and that the future lies in helping Africa not only to feed itself but also to integrate itself into global trade systems and thus make a contribution towards feeding the rest of the world. He is clearly indicating a role for innovation support when he says that:

\footnotetext{
"In agricultural production, scale and modern organization matters ... modern agriculture is all about marketing, capital, technology and innovation” ... and that there was a need for ... "a parallel development alongside efforts to improve peasant agriculture”.
}

Radical approaches towards supporting innovation at the level of organisations and communities in emerging economies include The Rural Innovations Network ${ }^{18}$, supported by the Villgro Foundation of Chennai, the Positive Deviance Initiative ${ }^{19}$, supported by the Rockefeller Foundation, and Changemakers ${ }^{20}$, which is an initiative launched by Ashoka ${ }^{21}$, the Indian organisation that develops open source solutions to social problems by utilising collaborative competitions to reveal the best solutions, and thence to refine, enrich, and implement them. Although these initiatives have arisen in the context of development aid, they provide us with many lessons in terms of the organisation of innovation in the challenging and relatively unfamiliar context of emerging economies. They may also

\footnotetext{
${ }^{16}$ http://www.worldagforum.org/

17 "The Bottom Billion - why the poorest countries are failing and what can be done about it” by Paul Collier, published in 2008 by Oxford University Press, ISBN 978-0-19-537463-6.

${ }^{18}$ http://www.rinovations.org/home_html

${ }^{19}$ http://www.positivedeviance.org/

${ }^{20}$ http://www.changemakers.net/en-us/competitions

${ }^{21}$ http://www.ashoka.org
} 
provide a useful starting point for understanding how to extend the existing international infrastructure of the Nordic countries to areas of business opportunity based on the next 4 billion. 


\section{Leverage of Innovation Hot-Spots}

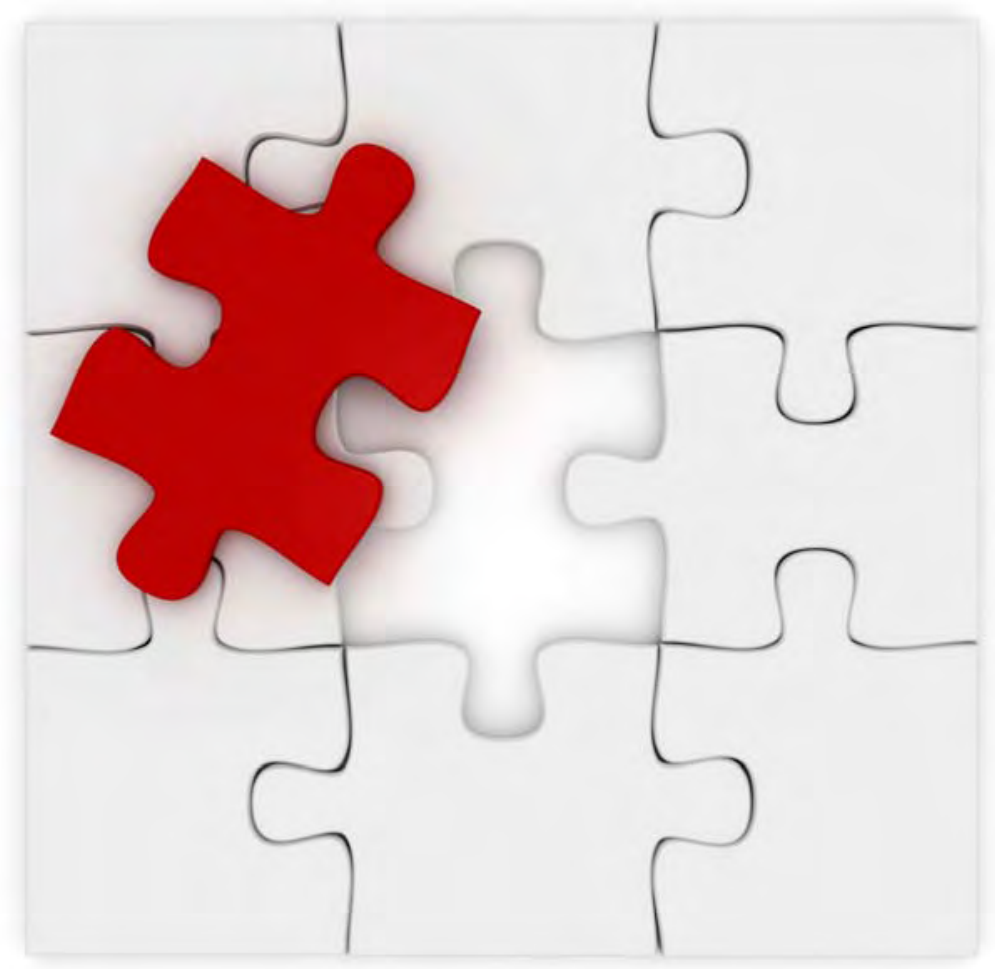


In an article in the Harvard Business Review ${ }^{22}$ John Kao has argued

\begin{abstract}
“That there's a whole new world of innovation opportunities opening up for companies - if you know where to look. Dozens of countries sponsor programmes to lure innovative enterprises to their home territories. Singapore offers R\&D grants to life-sciences and employee training. India provides talent management for some of the world's most sophisticated technology development work. Finland is becoming a global center for innovative design”.
\end{abstract}

Companies may capitalise on these and other innovation hot-spots first by identifying which countries offer the best match for their innovation strategy, and then by tapping into the relevant hot-spots and their innovation ecosystems. The main driving forces behind national policies for building innovation ecosystems and the resultant innovation hot-spots are closely related to the changes innovation has undergone in recent years. These changes have been made possible in particular by globalisation, IC technologies and the commodification of research. It is widely acknowledged that a timing of a nation's industrialisation has an impact on its future opportunities and its technology and innovation trajectories.

Countries that underwent early industrialisation, such as the UK and France, took more time than later developers such Germany, the US and others. However, a nation's standing in the global division of labour is not deterministic. The Asian Tigers have shown that small countries undergoing late industrialisation can make shifts in their respective production bases and ascend the global value chain. Singapore was the poorest country in the world when in 1965 it gained independence from Great Britain. Thirty years later, Singapore had developed into one of the world's richest and most sophisticated nations. China played hardly any role in international trade, production and investment until the late 1980 's, and yet today, China is a powerhouse in virtually all aspects of the global value chain linked to the production of goods and services. In order to understand the current global configuration of innovation hotspots it might be instructive to look at them in terms of their main driving forces, their main characteristics, the role of the state in their development, and the approximatetiming of their launch.

${ }^{22}$ John Kao:” Big Picture - Tapping the World’s Innovation Hot Spots” HBR, March 2009, pp. 109-114 
A Taxonomy of Global Innovation Hot-Spots

\begin{tabular}{|c|c|c|c|c|}
\hline $\begin{array}{l}\text { Driving forces } \\
\text { and focus }\end{array}$ & Nation/entity & Characteristics & $\begin{array}{l}\text { Role of state instru- } \\
\text { ments }\end{array}$ & $\begin{array}{l}\text { Time of } \\
\text { take off }\end{array}$ \\
\hline $\begin{array}{l}\text { Entrepreneurs } \\
\text { \& Venture } \\
\text { Capital }\end{array}$ & US, Israel & Market-led & $\begin{array}{l}\text { Tax incentives and } \\
\text { market institutions, e.g. } \\
\text { Nasdaq, and elite } \\
\text { universities }\end{array}$ & 1960's \\
\hline $\begin{array}{l}\text { Up-scaling of } \\
\text { national } \\
\text { innovation } \\
\text { ecosystems }\end{array}$ & $\begin{array}{l}\text { Finland, } \\
\text { Germany }\end{array}$ & Institution led & $\begin{array}{l}\text { Industry-university } \\
\text { collaboration, state } \\
\text { funds for VC, tech- } \\
\text { transfer, intermediaries }\end{array}$ & 1990's \\
\hline $\begin{array}{l}\text { Functional } \\
\text { industry bet }\end{array}$ & $\begin{array}{l}\text { France, Singa- } \\
\text { pore, Iceland }\end{array}$ & $\begin{array}{l}\text { Medium - high } \\
\text { degree of favour- } \\
\text { able state regulation }\end{array}$ & $\begin{array}{l}\text { Clusters and selection } \\
\text { of winner industries }\end{array}$ & 1990's \\
\hline $\begin{array}{l}\text { Large } \\
\text { numbers }\end{array}$ & China, India & $\begin{array}{l}\text { Both state and } \\
\text { market-led }\end{array}$ & $\begin{array}{l}\text { Massive investments in } \\
\text { R\&D, student enrolment } \\
\text { and attracting FDI }\end{array}$ & 1990's \\
\hline R\&D-centred & Russia & $\begin{array}{l}\text { High degree of state } \\
\text { dirigism }\end{array}$ & $\begin{array}{l}\text { Major investments in } \\
\text { STEM centres of } \\
\text { excellence }\end{array}$ & $\begin{array}{l}\text { Early 21st } \\
\text { century }\end{array}$ \\
\hline Finance hub & $\begin{array}{l}\text { UK, US, } \\
\text { (NyLon), China } \\
\text { (ShanKong) }\end{array}$ & $\begin{array}{l}\text { Global, market-led } \\
\text { until global financial } \\
\text { melt down in2008 }\end{array}$ & $\begin{array}{l}\text { Laissez-faire until } 2009 \\
\text { with minor use of state } \\
\text { instruments. }\end{array}$ & $\begin{array}{l}\text { NyLon mid } \\
1980 \text { s and } \\
\text { ShanKong } \\
\text { early 21st } \\
\text { century }\end{array}$ \\
\hline $\begin{array}{l}\text { Base of the } \\
\text { pyramid }\end{array}$ & $\begin{array}{l}\text { No single } \\
\text { nation - } \\
\text { instead poorest } \\
\text { people living in } \\
\text { Asia, Africa } \\
\text { and elsewhere }\end{array}$ & $\begin{array}{l}\text { Led by multinational } \\
\text { companies' search } \\
\text { for extreme cost- } \\
\text { efficient solutions for } \\
\text { re-export to more } \\
\text { affluent countries. } \\
\text { TATA's Nano-car } \\
\text { etc. }\end{array}$ & $\begin{array}{l}\text { No states have so far } \\
\text { played a significant } \\
\text { role in developing this } \\
\text { emerging and untradi- } \\
\text { tional innovation hot- } \\
\text { spot. Foreign aid } \\
\text { programmes could be } \\
\text { instrumental. }\end{array}$ & $\begin{array}{l}\text { Early 21st } \\
\text { century }\end{array}$ \\
\hline $\begin{array}{l}\text { Internet } \\
\text { communities }\end{array}$ & $\begin{array}{l}\text { YouTube, } \\
\text { Facebook, } \\
\text { Innocentive } \\
\text { etc. }\end{array}$ & $\begin{array}{l}\text { Global, people-led } \\
\text { and based on the } \\
\text { internet. }\end{array}$ & $\begin{array}{l}\text { No states have so far } \\
\text { played a role in devel- } \\
\text { oping global internet } \\
\text { communities. }\end{array}$ & $\begin{array}{l}\text { Early } 21 s t \\
\text { century. }\end{array}$ \\
\hline
\end{tabular}

Source: Jørn Bang Andersen: "Global Innovation Hot Spots - A Taxonomy", 2009, Nordic Innovation Center, Nordic Council of Ministers

The strategic path selected for the development of national innovation hotspots largely resembles that taken by several nations during the earlier phases of their industrialisation process. The difference being that the focus in the 21st century is directed on innovation and not industrialisation. This suggests that the institutions supporting economic growth tend to use the 
same skills that they have accumulated over time. The ability of these institutions to adapt to changing circumstances, such as globalisation, provides a guide to how well a nation will steer its destiny in the context of the global value chain towards its ultimate prosperity or partial failure.

According to the taxonomy above, it can be argued that a given nation with particular strengths within certain areas such as entrepreneurship and venture capital (e.g., US, Israel), or the development of institution-led ecosystems such as Finland and, to some extent, the other Nordic countries. Nonetheless, all nations will have policies focusing on all these elements. The point here is that different countries have different strengths, and these strengths tend to be reinforced by the state instruments that are applied. It is worth noting that China and India can be characterised as being less restrained than Europe, the US or Russia in terms of their orthodoxies related to the role of the market versus the state, and that in reality they often adopt a more pragmatic view. This view corresponds with Deng Chou Ping who once said that "I don't care if the cat is black or white, as long as it catches the mouse". What he meant was that if the Communist system can build factories it is good. If the free enterprise system can build a factory, that's good too. Indeed, the entrance of China and India into the world market with their innovative capacities in many ways represent the major challenge in terms of change for the rest of the world.

Finally, the "bottom-of-the-pyramid" and internet communities are included as global innovation hot-spots because both phenomena have a huge potential impact on future innovation loci. However, these are also areas which are beyond our traditional spatial understanding of hot-spots and are thus seldom included in discussions about where to look for or tap into global innovation hot-spots.

One issue is how different nations develop their innovation hot-spots at home. Another equally important aspect is how they leverage their national innovation hot-spots onto the global stage and tap into foreign hot-spots. For decades, the US has enjoyed a privileged position in that it has been able to attract the best students and entrepreneurial talent to their universities and to Silicon Valley. This has never been an option for the Nordic countries. The Nordic countries taken together produce about $7 \%$ of the world's R\&D results. Their global impact in terms of innovation in its broadest sense is probably somewhat similar. The Nordic countries have 
been pioneers in terms of the establishment of innovation centres in a number of global innovation-hot spots, notably in Silicon Valley, Shanghai, Tokyo, New Delhi, Munich, Seoul, St. Petersburg - to name just a few.

In the national taxonomy of innovation hot-spots, the Nordic countries are grouped in the category characterised by being institution-led. In other words, they construct ecosystems around tripartite partnerships involving the industrial sector, academia, and the state, incorporating support institutions such as growth funds designed to assist the market with venture capital functioning, etc. However, if we examine this at a more detailed level, it turns out that there are some fundamental differences even within such a relatively homogenous group such as the Nordic countries.

\section{Divergence of Nordic Innovation Ecosystems}

\begin{tabular}{|c|c|c|c|}
\hline & $\begin{array}{l}\text { Domestic driving forces for } \\
\text { innovation ecosystems }\end{array}$ & $\begin{array}{l}\text { Focus for globalising } \\
\text { national innovation } \\
\text { ecosystem }\end{array}$ & Global industry profile \\
\hline Sweden & $\begin{array}{l}\text { World's highest R\&D } \\
\text { spending as a percentage } \\
\text { of GDP. Has no national } \\
\text { innovation policy. Has } \\
\text { virtually no industry-led } \\
\text { technology transfer system, } \\
\text { state-global industry dia- } \\
\text { logue. }\end{array}$ & $\begin{array}{l}\text { Strong focus on the } \\
\text { acquisition of scientific } \\
\text { intelligence from global } \\
\text { hot-spots. Vehicle ITPS } \\
\text { offices }\end{array}$ & $\begin{array}{l}\text { Leading global multina- } \\
\text { tionals in manufacturing, } \\
\text { e.g. Volvo and Ericsson; } \\
\text { and in services e.g. H\&M } \\
\text { and IKEA }\end{array}$ \\
\hline Finland & $\begin{array}{l}\text { World's second highest } \\
\text { R\&D spending as a per- } \\
\text { centage of GDP. Decade- } \\
\text { long focus on science, } \\
\text { technology and education. } \\
2008 \text { - a shift in focus } \\
\text { towards more user-driven } \\
\text { innovation and markets. } \\
\text { Strong role of state-initiated } \\
\text { technology institutions such } \\
\text { as Tekes and Sitra. }\end{array}$ & $\begin{array}{l}\text { Strong focus on moving } \\
\text { the entire national } \\
\text { Finnish innovation } \\
\text { ecosystem to global } \\
\text { hot-spots. Combined } \\
\text { technology, innovation } \\
\text { and export focus for } \\
\text { activities. Vehicle- } \\
\text { Finnodes. }\end{array}$ & $\begin{array}{l}\text { NOKIA is the dominant } \\
\text { factor in national industry } \\
\text { profile and national inno- } \\
\text { vation ecosystem. }\end{array}$ \\
\hline
\end{tabular}




\begin{tabular}{|c|c|c|c|}
\hline & $\begin{array}{l}\text { Domestic driving forces for } \\
\text { innovation ecosystems }\end{array}$ & $\begin{array}{l}\text { Focus for globalising } \\
\text { national innovation } \\
\text { ecosystem }\end{array}$ & Global industry profile \\
\hline Denmark & $\begin{array}{l}\text { World's first country to } \\
\text { adopt a design policy, and } \\
\text { a programme for user- } \\
\text { driven innovation. In gen- } \\
\text { eral exhibits a strong focus } \\
\text { on market driven solutions. } \\
\text { Strong industry-led tech- } \\
\text { nology transfer system } \\
\text { (GTS). }\end{array}$ & $\begin{array}{l}\text { Strong focus on gaining } \\
\text { access to near-market } \\
\text { relevant technologies } \\
\text { and solutions. Com- } \\
\text { bines innovation, export } \\
\text { and investment promo- } \\
\text { tion with less focus on } \\
\text { science. Vehicle - } \\
\text { Innovation Centre } \\
\text { Denmark }\end{array}$ & $\begin{array}{l}\text { Primary global companies } \\
\text { within Transport, e.g. } \\
\text { Maersk Shipping. Food- } \\
\text { stuffs. e.g Arla and Carls- } \\
\text { berg and global leader in } \\
\text { niche markets in pharma- } \\
\text { ceuticals such as Novo } \\
\text { Nordic, Novozymes. Also } \\
\text { Vestas, the global leader } \\
\text { in in wind turbines. . }\end{array}$ \\
\hline Norway & $\begin{array}{l}\text { World's second richest } \\
\text { country per capita. Owns } \\
1.6 \% \text { of all European } \\
\text { companies listed on the } \\
\text { stock exchange. Natural } \\
\text { resource-based industry } \\
\text { with strong state ownership } \\
\text { and involvement. Medium } \\
\text { to low score on official R\&D } \\
\text { statistics. Strong element of } \\
\text { applied industry science } \\
\text { institutes, e.g. SINTEF. }\end{array}$ & $\begin{array}{l}\text { No particular leading } \\
\text { focus preferring a global } \\
\text { presence for all indus- } \\
\text { tries. } \\
\text { Vehicle - Innovation } \\
\text { Norway }\end{array}$ & $\begin{array}{l}\text { Primary global companies } \\
\text { within oil and gas - Sta- } \\
\text { toilHydro and fisheries } \\
\text { salmon production }\end{array}$ \\
\hline Iceland & $\begin{array}{l}\text { Strongest entrepreneurial } \\
\text { culture in the Nordic region. }\end{array}$ & $\begin{array}{l}\text { Has no global presence } \\
\text { in terms of innovation } \\
\text { centres or export pro- } \\
\text { motion. Vehicle - ope- } \\
\text { rates partly via Nordic } \\
\text { partners. }\end{array}$ & $\begin{array}{l}\text { Primary global industry } \\
\text { profile related to fisheries } \\
\text { and aluminium smelters } \\
\text { relying on geothermal } \\
\text { power as a cheap energy } \\
\text { resource. }\end{array}$ \\
\hline $\begin{array}{l}\text { Nordic } \\
\text { Council of } \\
\text { Ministers }\end{array}$ & $\begin{array}{l}\text { One of Europe's and the } \\
\text { world's most developed } \\
\text { examples of regional co- } \\
\text { operation. }\end{array}$ & $\begin{array}{l}\text { Strong focus on global- } \\
\text { isation initiatives within } \\
\text { innovation. Vehicle - } \\
\text { pilot financing program- } \\
\text { me for Nordic innova- } \\
\text { tion representations in } \\
\text { Asia }\end{array}$ & $\begin{array}{l}\text { Relatively weak global } \\
\text { profile. Primarily known as } \\
\text { Scandinavia or individual } \\
\text { regional multinational } \\
\text { companies. }\end{array}$ \\
\hline
\end{tabular}

Source: Jørn B. Andersen, Nordic Innovation Center, Nordic Council of Ministers, 2009

A central issue in terms of the divergence between the Nordic countries is that companies tend to adopt a domestic pattern in their ways of engaging with state authorities, and they tend to organise their operations around these patterns. Moreover, companies frequently bring these domestic idiosyncracies with them when they enter foreign markets. The last decade of globalisation may have done something to weaken these national corporate traits, but they should probably not be dismissed out of hand. In a Nordic context, the variations in terms of industry profiles, domestic driving forces for innovation ecosystems and their modus operandi for 
globalisation may erect barriers. It is probable that such barriers require better understanding if the achievement of joint Nordic solutions, such as the establishment of Nordic innovation centres in Asia or elsewhere in the world, remains the target.

An alternative approach to joint Nordic initiatives could be to focus on the bottom-of-the-pyramid and Internet communities. Both of these emerging hot-spots have the advantage of being in their infancy. There is no entrenched state-industry pattern to deal with, and Nordic initiatives would therefore not come into conflict with domestic Nordic interests per se. Nordic experimentation would provide the countries concerned with insights into future avenues available for innovation activity. The role and relevance of hot-spots will change over time. There is a need to develop and consciously promote hot-spots throughout the Nordic countries by initiatives such as the identification of and tapping into hot-spots abroad, which can then be used as platforms for:

- The international expansion and development of Nordic businesses as well as their use as possible sources of information on innovation.

- Radical new approaches and the establishment of good practice in areas such as health care, town planning and public administration, and public sector innovation in general.

The five Nordic countries have world-class capabilities in areas such as agricultural production, food processing, logistics, retail, distribution, design, mobile phone systems and oil exploration. These are all areas which bottom-of-the-pyramid economies lack. The knowledge, knowhow or ability to execute initiatives in these areas is not easy to codify. These forms of intellectual and social capital are deeply tacit and diffuse. They exist at the level of the organisation rather than that of the individual. They are the result of the values and attitudes of employees and the unique culture inherent in every organisation that is necessary to support work practices which in turn promote high performance systems and organisational structures.

Most Nordic countries have experienced success in exporting their systems. For example, in the area of agricultural production, Denmark has had considerable success and arguably leads the world in its ability to transfer this kind of know-how. In the future, the successful export of 
organisational and management practices will rely more on partnering than on patenting. It will require a new vision, a new vocabulary, and a new set of methods for prosperity creation. It corresponds to a new and emerging form of economic globalisation, representing an estimated $\$ 5$ trillion opportunity. 


\section{Services and Innovation}

c 10

$f$ credit tcy ig. All charges relatimed to you at des tivered
osing Costs del PROFESSIONAL AStiated by

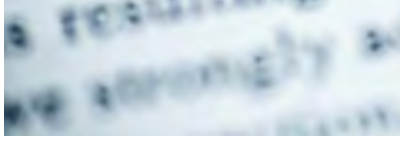


In 1999, an OECD Business and Industry Policy Forum concluded that:

\begin{abstract}
"Services are transforming OECD economies on a massive scale, but are still impeded by regulations and policies that stifle innovation and competition. Comprehensive reforms need to be pursued internationally as well as in individual OECD countries. With manufacturing slipping to less than $20 \%$ of GDP and the role of services rising to more than 70\% in some OECD countries, services are seen as playing a principal role in economies." ${ }^{23}$ And almost $80 \%$ of all employed in the Nordic countries in 2009 work within the service sector $^{24}$.
\end{abstract}

In 2006-2008, NICe funded the comprehensive project termed ICONs Innovation and the International Competitiveness Nordic Services. The project's focus is grounded in the following:

\begin{abstract}
"Most studies in the field of innovation have focused on the relationship between innovation and foreign performance in manufacturing industries, while neglecting the service sector - arguably due to the lack of data availability, and to the difficulty of conceptualising the patterns and performance of service innovation". ${ }^{25}$.

The aim of the ICONs project was to change that, and in subsequent years several Nordic initiatives linked to services have been launched.
\end{abstract}

The relationship between services and manufacturing is complex and not always easily understood. Accountancy services provide an example of this. Prior to the Internet age, accountancy was a personal service. Currently, accountancy advice is available on a CD-ROM disk and can be purchased in a standard format off the shelf. In statistical terms, accountance thus becomes a goods product. If the same information is made available for purchase on a website it becomes a service. This example may seem oversimplistic, but it illustrates the complexity involved in considering what constitutes a service as opposed to a goods product in physical terms.

\footnotetext{
${ }^{23} \mathrm{http} / / /$ www.oecd.org/dataoecd/10/33/2090561.pdf

${ }^{24}$ www.ixda.org, First Nordic Conference on Service Design and Service innovation, Oslo, 2009

${ }^{25} \mathrm{http} / /$ english.nupi.no/virksomheten/forskningsavdelinger/ avdeling_for_internasjonal_oekonomi/prosjekter/innovation_and_the_international_competitive ness_of_nordic_services_icons
} 
In the 1920's, the Ford Motor Company built the River Rouge assembly plant in Michigan. Coal and iron ore were brought in one end and finished automobiles emerged at the other. Today, this would seem to be an aberrant practice some sort of bizarre theme park. In fact, the contemporary technology of scale made such work practices entirely rational. There is a great similarity between current state of the banking industry and the automobile manufacturers that built that plant nearly 80 years ago. Today's banks, in much the same way as Henry Ford in the 1920's, are learning the techniques of mass production for the first time.

There was a time when a bank would lend or provide a mortgage to a business. It would take the asset and put it on their books in much the same way as a museum exhibits a piece of art on a wall or under glass - to be admired and valued for its security and constant rate of return. Times have changed. Banks now take those assets, structure them into pools, and sell securities based on those pools to institutional investors and portfolio managers. In effect, they use their balance sheets not as museum exhibits, but as car parks - temporary holding spaces where they can bundle up assets before selling them on to investors who have a far greater interest in holding those assets for the long term. The bank has thus evolved from being a museum which acquired only the finest assets, holding and exhibiting them in perpetuity, into a manufacturing plant, providing a product for the secondary market. Just as Henry Ford did 80 years ago, banks today are focusing on manufacturing standardised products at predictable rates, under standard norms of quality, and are teaching their workforces to produce that product as quickly and as efficiently as possible.

Technology has been key to this process. The reason that we observe a services economy today, and why we gather to talk about it and recognise its importance, is because technology has allowed service industries to gain the operational leverage that manufacturing achieved 100 years ago. In addition to banks, health service systems, telephone and telecommunications networks, and distribution and retailing firms all provide further examples of sectors that have been able to benefit from economies of scale. As a result, we are now living in a world where globalscale service companies exist for the first time, whereas we have seen global manufacturing companies for 50 years or more. ${ }^{26}$

It is an established fact that most people in the Nordic countries are employed within what is classified as the service economy, where team work, project management, coaching and so forth, are familiar instruments utilised for improving current service economy organisations. However, it is possible that we are still in a situation of trying to understand productivity and performance in terms of the logic of the industrial

\footnotetext{
${ }^{26}$ OECD, STI The Service Economy, Paris 2000, Ehrlich 1999.
} 
age. The management guru W. Edwards Deming taught the Japanese that "people get rewarded for conforming", and that it was for this reason that US industry was declining. To remedy the situation Deming suggested that organisations should abolish the annual performance appraisal. Demning went on to conclude that without pride in your work your only incentive in having a job is to obtain money. And there is no joy in that. To illustrate his point that it is virtually impossible to measure the performance of an invidual in the context of a team he derived the following simple mathematical equation;

$$
x+y+x y=8
$$

in which he argued that if $x$ and $y$ represent the respective contributions made by the individual and the system, and $x y$ the contribution made by the interaction between individuals and the system, how can you in all honesty accurately extract the $x$ component, i.e. the individual's contribution? It is mathematically impossible ${ }^{27}$.

The reader might ask- what has this to do with the service economy? The answer may be - Quite a lot, and in several ways. The service economy deals essentially with intangibles. Success depends on factors such as the educational levels of the work force, organisation, management and intellectual capital, innovative capacities and skills defined in the broadest sense.

However, most organisations continue by means of various creative devices to try to develop new schemes in which performance and innovation is evaluated based on the appraisal of the $x$ variable, and not on the team. Moreover, people must be prepared if they are to become innovative. Innovation is a discipline which must be managed and measured if it is to be seen to be successful. If we want Nordic companies to become more productive and to enhance their returns on innovation, we cannot ignore services as a process. Every company has to consider how to apply tools and processes, and to adopt disciplined ways of thinking.

In an interview with the New York Times, Irving Wladawsky-Berger, IBM's vice president for technical strategy and innovation, and a visiting professor at the Massachusetts Institute of Technology noted that:

\footnotetext{
${ }^{27}$ Andrew Razeghi: HOPE how triumphant leaders create the future, pp. 120-121, 2006, Josey-Bass, San Francisco, United States
} 
Corporations need to help prepare university students for the new servicesbased economy. Information technology is becoming embedded in all aspects of business, society and our personal lives. We see an increasing requirement to apply technology, engineering and disciplined thinking and design to the people aspect of businesses. That's really what we mean by services.”

We might also examine Toyota and ask why it took American and European car manufacturers so long to narrow the efficiency gap with the Japanese corporation. The reason is, in large part, that it took Toyota's competitors decades to ferret out the radical management principle at the heart of Toyota's capacity for relentless improvement. Unlike its Western rivals, Toyota has believed for a long time that first-line employees can be more than cogs in a soul-less manufacturing machine; they can be problem-solvers, innovators, and change agents. ${ }^{28}$

Manufacturing is becoming increasingly services-dependent, and an increasing proportion of service companies are becoming integrated into networks with other economic sectors. Strong links are also developing between goods and services sectors due to complementarities of demand. Such integration implies that separating the two increasingly creates an artificial division that is not reflected in the character of production processes.

Consider the amount of effort invested in attempts to define and characterise services. It seems reasonable to conclude that what we call the service or tertiary sector is so diverse that there can only be a marginal value attached to seeking a coherent and unique (positive) characterisation of this sector. It seems that John Stuart Mill's conclusion still remains valid;

"I have made little use of the popular distinction of industry into [primary, secondary and tertiary35]. For, in truth, this division fulfils very badly the purposes of a classification” (Mill 1869).

Historically, the Nordic countries have invested a comparatively high proportion of their GDP in public sector services. This is due to their belief in, and a consequent focus directed towards, a societal model centred on a comprehensive welfare system and related services. The Nordic countries have recently started to examine innovation among public ser-

\footnotetext{
${ }^{28}$ Gary Hamel: The What, Why and How of Managment Innovation: Harvard Business Review, February 2006.
} 
vice sector organisations. To date, most focus seems to have been on how to involve the users of the offered services in more systematic ways, supported by innovation programmes promoting user-driven creativity within the public sector.

However, in order to develop adequate organisations it appears that we must also adopt a new focus directed towards disciplines and other factors such as management, public sector organisations and innovation at all levels of society. In particular, focus is required on our business schools and current management teaching methods. We must also focus on how these skills are developed and integrated into existing businesses, organisations and the economy at large. Some of the the innovations which have generated the greatest impact within the last 100 years have occurred within organisations. BusinessWeek provided an illustration of this in March 2009, as is shown in the two tables below.

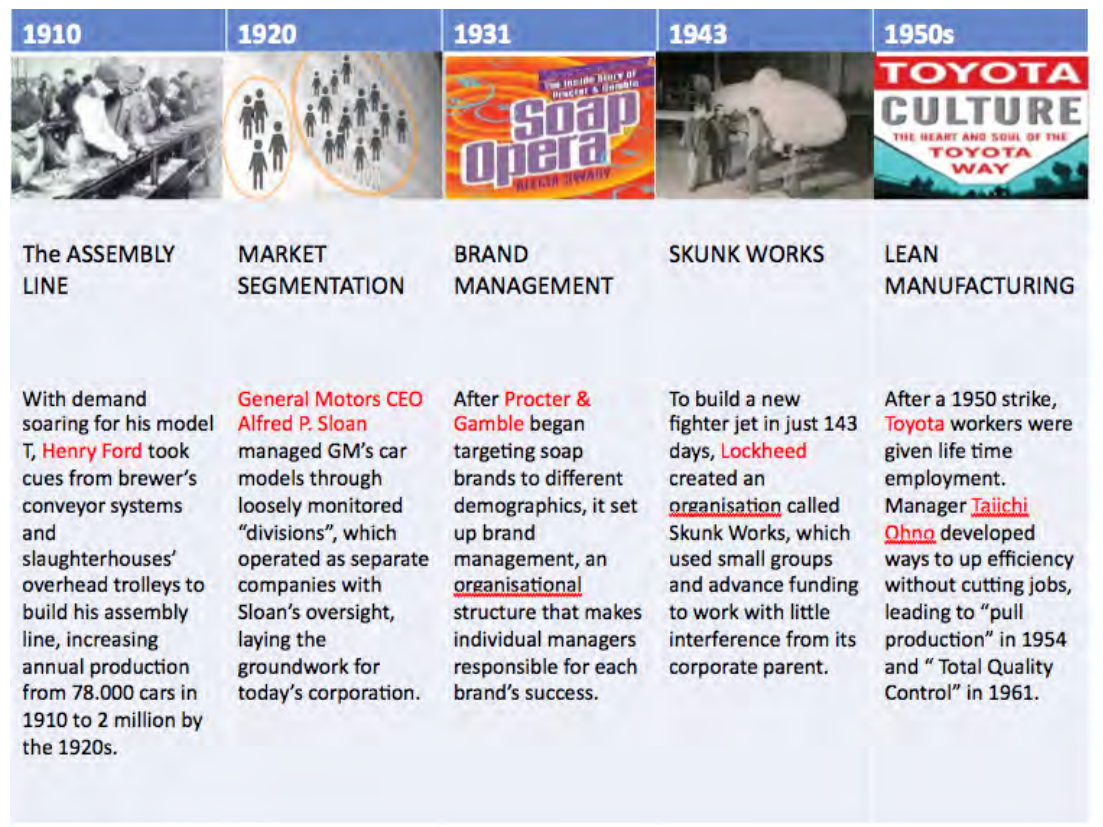




\begin{tabular}{|c|c|c|c|c|c|}
\hline 1967 & 1973 & 1987 & 1989 & 1990 & $2000 s$ \\
\hline $\begin{array}{l}\text { SCENARIO } \\
\text { PLANNING }\end{array}$ & $\begin{array}{l}360-D E G R E E \\
\text { REVIEWS }\end{array}$ & SIX SIGMA & OUTSOURCING & $\begin{array}{l}\text { RE- } \\
\text { ENGINEERING }\end{array}$ & $\begin{array}{l}\text { OPEN } \\
\text { INNOVATION }\end{array}$ \\
\hline $\begin{array}{l}\text { The practice } \\
\text { involves } \\
\text { envisioning } \\
\text { multiple future } \\
\text { events and } \\
\text { developing plans } \\
\text { for responding to } \\
\text { them. Shell first } \\
\text { experimented } \\
\text { with scenario } \\
\text { planning in 1967, } \\
\text { helping to } \\
\text { navigate the oil } \\
\text { shock of the } \\
\text { 1970s. }\end{array}$ & $\begin{array}{l}\text { Getting feed-back } \\
\text { from peers, } \\
\text { managers, and } \\
\text { underlings may be } \\
\text { the scourge of } \\
\text { time strapped } \\
\text { managers. But } \\
\text { when companies } \\
\text { first adopted } \\
\text { these reviews } \\
\text { (Dupont) was first } \\
\text { in } 1973 \text {, they were } \\
\text { seen as a leap } \\
\text { ahead. }\end{array}$ & $\begin{array}{l}\text { Invented at } \\
\text { Motorola, the } \\
\text { process, designed } \\
\text { to reduce defects } \\
\text { and increase } \\
\text { efficiency, is most } \\
\text { associated with } \\
\text { General Electric. } \\
\text { Widely used } \\
\text { today, the jargon } \\
\text { laden tool has } \\
\text { been the butt of } \\
\text { recent jokes on TV } \\
\text { sitcoms. }\end{array}$ & $\begin{array}{l}\text { While the practice } \\
\text { of hiring outside } \\
\text { tech services } \\
\text { dates to the } \\
1960 \text { s, } \\
\text { outsourcing took } \\
\text { root later. In } 1989 \\
\text { IBM landed a deal } \\
\text { to manage } \\
\text { Kodak's data- } \\
\text { processing needs. } \\
\text { By the } 1990 \text { s, } \\
\text { much of that work } \\
\text { stared moving } \\
\text { offshore. }\end{array}$ & $\begin{array}{l}\text { Technically } \\
\text { defined as a } \\
\text { radical rethinking } \\
\text { of processes, the } \\
\text { fad was often } \\
\text { associated with } \\
\text { the lay-offs it } \\
\text { spurred and with } \\
\text { consultant } \\
\text { Michael Hammer } \\
\text { who cited Ford in } \\
\text { his } 1990 \text { article " } \\
\text { Reengineering } \\
\text { Work: Don't } \\
\text { automate, } \\
\text { Obliterate". }\end{array}$ & $\begin{array}{l}\text { Many companies } \\
\text { are ditching fears } \\
\text { of "not invented } \\
\text { here". Instead, } \\
\text { they are buying or } \\
\text { lincensing } \\
\text { inventions and } \\
\text { collaborating with } \\
\text { companies and } \\
\text { customers. } \\
\text { Procter \& Gamble } \\
\text { aims to capture } \\
\text { half of its } \\
\text { innovations from } \\
\text { outsiders. }\end{array}$ \\
\hline
\end{tabular}

Source: BusinessWeek, Special Issue: Managing Smarter, Game Changing Ideas for Business, March 23 and $30,09$.

Gary Hammel ${ }^{29}$ argues that what really fuels long-term success in business is not operational excellence or new business models, but management innovation - new ways of mobilizing talent, allocating resources and building strategies. Peter Drucker, writing in $1993^{30}$, states that "there has been a decade of innovations in all areas ... the most innovative area may have been management itself."

Management innovation not only incorporates new ways of managing innovation, but goes far beyond that in the sense that it also includes the invention of the corporation, mass production, the assembly line, the corporate research laboratory, the living laboratory and the corporate university. It also includes the invention of total quality management, 6 sigma, just-in-time inventory management, benchmarking as a management tool, outsourcing, and a whole range of project management techniques and models applied in areas as diverse as construction and software development. It is clearly of great importance, not only in itself, but also as the enabler of technical innovation. However, management inno-

29 “The Future of Management” by Gary Hammel with Bill Breen, published in 2007 by Harvard Business School Press, ISBN 978-1-4221-0250-3

${ }^{30}$ Preface to a new edition of "Innovation and Entrepreneurship" by Peter F. Drucker first published in 1985, available from Elsevier, ISBN 978-0-7506-8508-5. 
vation is essentially off-the-radar of those studying innovation systems at national and European level. It is a form of hidden innovation.

Management innovation is not systematically addressed by managers even in major organisations. Most companies lack a formal process for disciplined management innovation. Management innovations can also be traded. Vehicles for the diffusion of management innovation do exist in the form of the business literature, the schools of management, management consulting companies, corporate universities and franchise systems. These arenas are all but ignored in the current debate about how to shape innovation policy for the future. Understanding what it is, where it is, and how it happens is important to both industry and government. It is possible that there is a need to invest in new non-traditional forms of research, together with education and training in recently evolved and related disciplines and new institutions like the Management Innovation $\mathrm{Lab}^{31}$ recently set up by Gary Hammel.

The NICe-funded InnoTools project has been examining how innovation develops in companies throughout the Nordic and Baltic region. They have worked with more than 60 managers in 8 companies from 7 countries with employee numbers ranging from 14 to more than 30,000. Thaim of the project has been to determine where innovation is located and how it develops under the following 12 headings ${ }^{32}$ :

- Offerings: Products and services sold.

- Platforms: The use of components and technologies that provide the basis for a portfolio of offerings.

- Solutions: Customised and integrated combinations of offerings that solve end-to-end customer problems.

- Customers: Discovering unmet customer needs

- Customer Experience: Everything a customer sees, hears and feels, including customer interactions.

- Value Capture: Revenue streams and methods of payment

- Processes: How things get done in terms of efficiency, effectiveness and performance.

\footnotetext{
${ }^{31}$ http://www.managementlab.org/

${ }^{32}$ Based on an article of Sawney, Wolcott and Arroniz published in Spring 2006 Vol. 47 No. 3 of the MIT Sloan Management Review entitled "The 12 different ways for companies to innovate".
} 
- Organisation: Control, management, and the form, function and scope of activities

- Supply Chain: Sourcing of components and human resources etc.

- Presence: Where and how you meet customers; sales channels

- Networking: Network intelligence; how you utilise the internet to reach new customers.

- Brand: Establishing, developing, positioning, leveraging, stretching and extending brands to create new meaning and value

A competition-oriented analysis of a company in terms of how it is positioned in each of these areas, and thus its level of exposure to opportunities for innovation, is referred to as "Innovation Radar". The method has proved to be very helpful to the companies involved. Note that there is no mention of research or research labs in this list. These represent input variables to any or all of the listed aspects of a business. They are input variables only in the sense that bricks and mortar and planks of wood are components of a building. Architecture, location, design and presentation are all vital elements of a building, but are arguably not sufficient in themselves to ensure a successful outcome. 

Supporting Open Innovation

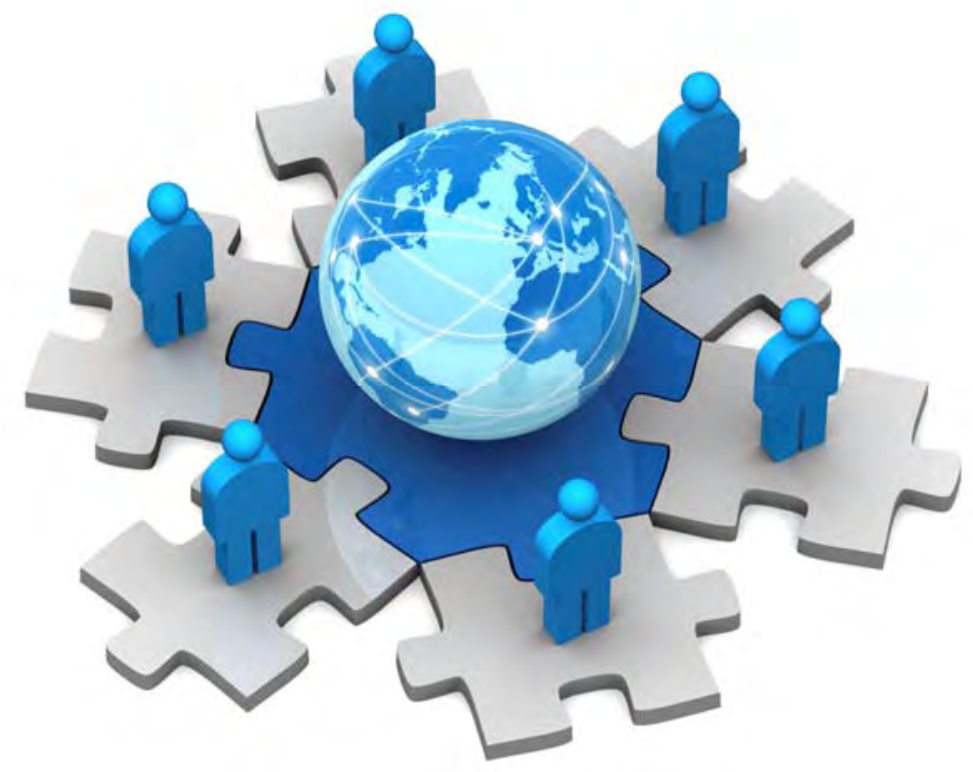


From the perspective of innovation policy that promotes networking, there is particular reason to monitor the routes linking subsystems. "Connect and develop" is the name of the open innovation model adopted by Procter \& Gamble and has been well-documented in the Harvard Business Review. This approach requires a very different network of channels to the traditional "research and develop" model. Universities, for example, should take a fresh look at how they move within these networks, because the innovation environment is changing for the more open and practice-oriented organisations. Network-based innovation policies aim at monitoring the condition of these routes (social capital and its various forms) and developing the necessary practical tools for improving network activities ${ }^{33}$.

Open innovation deals with new ways of organising economic activities.

\section{Changing the nature of innovation ${ }^{34}$}

\begin{tabular}{ll}
\hline Invention & Innovation \\
\hline Linear innovation model & Dynamic innovation mode \\
Build to forecasted demand & Sense and respond to demand \\
Independent & Inter-dependent \\
Single discipline & Multidisciplinary \\
Product functions & Value to customer \\
Local R\&D teams & Globalized $24 / 7$ collaboration \\
\hline
\end{tabular}

To some extent, open innovation has been around for longer than most of us care to think. Companies have always co-operated with the suppliers within their value chain and have sought innovative solutions outside their own organisation. The major and more recent changes have involved the opportunity to get things done on a global scale and 24/7 combined with the increased levels of competition to gain access to the best global innovation eco-environments and the best talent. Achieving this requires a new and alternative organisational model in which a company is able to compete equally well well and prosper simply by directing focus towards its inherent capacity for innovation.

The successful organisation of a new global model for open innovation requires new organisational and personal skills among all those in-

\footnotetext{
${ }^{33}$ Quote from Sitra, 2008 Finland: http://www.sitra.fi/en/News/articles/ Article_2008-01-22.htm

${ }^{34}$ Source: Innovation Ecosystems and Prosperity, March 29 2005, Egils Milbergs, Center for Accelerating Innovation
} 
volved. To date, knowledge about open innovation has been drawn mainly from cases such as P\&G's "connect and develop" approach, the internet-based Innocentive solution, 9Sigma, and from multinational corporations such as IBM, Google, Philips, Nokia, Electrolux and Intel, to mane but a few. Lesser known examples include those of SMEs such Quilt and Gabriel in Denmark and Beneq in Finland

Small- and medium-sized Nordic companies share a good starting point for developing organisational models which suit their needs, based on open innovation. Arguably, the Nordic business culture displays very low levels of hierarchical structure and is more open to co-operation. However, it seems obvious that Nordic SMEs would benefit somewhat if there were more case histories relevant to their own situation, thus enabling them to accumulate more knowledge about what is good practice in terms of organising open innovation in the SME setting.

Currently, initiatives are surfacing in the Nordic region addressing the development of new organisational models involving open innovation. For example, the Norwegian Forum for Open Innovation and the organisation Nordic Open Innovation have emerged, together with national government programmes. These are good and relevant initiatives. However, if the Nordic region is to lead the way and reap the full benefits of open innovation, a stronger focus is probably required not only on individual cases, but equally also on the approaches to organising open innovation within an entire value chain or within an innovation ecosystem. Kraft Foods represents an example of a company that is retreating from the model by which the value chain is utilised to cut costs. Today Kraft Foods favour a model by which the company recognises its value chain as a valuable source for innovation Nordic innovation policy and the Nordic Innovation Centre both appear be constitute a natural locus for the accumulation of Nordic intelligence and practical know-how, combined with the dissemination of knowledge as to how open innovation can work in these different settings. Finally, it is important to involve the higher education institutions in this work, since they will also have to reorganise themselves in various ways if they too are to fit into these new organisational models for open innovation. 



\section{Innovation Indicators}

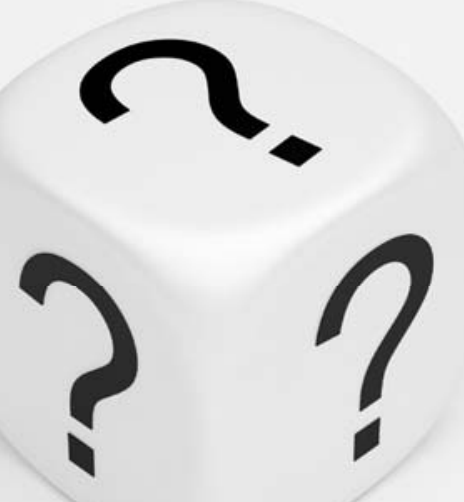


In 2008, the Nordic Innovation Centre finalised five projects dealing with Nordic Innovation Indicators, and arranged a conference with more than 80 participants and the involvement of the EU, the OECD, and participation from most EU countries. In 2009, the Nordic Council of Ministers and NICe co-sponsored the Nordic Innovation Monitor by FORA, and a report which investigates new ways of applying indicators in innovation policies. This chapter examines the current discussion on innovation indicators, and discusses why the established models for measuring innovation increasingly are called into question by leading scholars, innovation agencies and countries all over the world. The discussion regarding current methods of measuring innovation is not only restricted to academia. It is highly relevant to the issue of innovation policies to the extent that indicators shape both the policies and programmes for innovation.

The basic document of innovation indicators used in the Nordic countries and elsewhere is called the "Oslo Manual". The manual defines a firm as innovative if it has introduced at least one product or incorporated one process that was new to the firm itself.

The key to understanding why innovation indicators matter starts from the vantage point that $R \& D$ indicators are still the most commonly accepted means of evaluating innovation efforts. R\&D plays a major role as a source of inventions, and fits well into a science-push or linear model of innovation. Although most people working with innovation will denounce this model as outdated, it is a fact that it still dominates the way in which innovative activities are measured within the OECD, the EU and Nordic countries.

A UNU-MERIT analysis of 176 academic articles in English using CIS data found that only $5 \%$ of these explored innovation strategies, performance or other characteristics of innovative sharing from a systemic perspective. Moreover, of the 176 papers only $12 \%$ were found to make any policy recommendations, and only very few discussed the relevance of the results to policy. The UNU-MERIT study notes that to date, one of the main problems involves the poor links between the policy community and the statistical offices and academics that utilise CIS data.

R\&D indicators are primarily suited to the assessment of inventions and goods manufacture. This bias towards manufacturing activities means that concepts such as user-driven innovation, open-innovation and changes in management and organisation are not "considered" to be in- 
novative activities. Moreover, private and public sector activities are virtually never categorised as innovation.

This must be contrasted with the fact that around $70-80 \%$ of all economic activity in the Nordic countries takes place within the services sector. This is also true for many other OECD countries. Nevertheless, the focus of innovation indicators from $R \& D$, and the subsequent spillover into innovation policy programmes receives major emphasis in the EU's Lisbon Agenda. This is the case in particular in the Barcelona Initiative which stipulates a target whereby all EU countries should exhibit an R\&D intensity of 3\% of gross domestic product (GDP) by 2010 . This $3 \%$ goal has become the official innovation policy target in all the Nordic countries since its announcement.

However, the 3\% target has its own perverse built-in logic, which has been exposed by an increasing number of scholars studying the subject. One of the arguments is that a country with a very efficient innovation policy resulting in steady economic growth will have greater difficulty in achieving the 3\% R\&D GDP target than a country with a declining GDP. In fact, the global financial crisis has probably brought more EU countries closer to the 3\% figure than ever before, as a direct result of their shrinking economic growth. Furthermore, Luc Soete and others talk about a European "research paradox", in terms of the fact that; "contrary to economic theory and intuition, a strong scientific research base does not appear to go hand in hand with strong technological and economic performance, rather the contrary" (Soete 2006). This paradox is also an issue from a Nordic perspective.

The Norwegian paradox is that a country that invests only 1.7 percent of GDP in R\&D has become one of the richest countries in the world. The Swedish paradox is that a country that invests close to 4 percent in $R \& D$, and which is not significantly more innovative than Norway, is actually less productive. These paradoxes can partly be explained by industrial structure. Both Sweden and Finland are hosts to a handful of large, "hightech" companies. This explains why these countries score so well in terms of R\&D indicators. In contrast, Iceland and Norway both support business sectors dominated by small enterprises, often in raw material-based industries or services ehich, in relative terms, do not normally invest heavily in R\&D. 
In the UK, NESTA, which is an advisory body to the UK government on innovation, has carried out several studies which show that current innovation indicators cannot explain the relative success of companies operating in most service sectors ranking from retail to oil-drilling. NESTA also found that the OECD's aggregate measures across sectors are simply too crude to cater for how innovation develops within specific sectors. It has therefore initiated the development of a sector-relevant innovation index. NESTA categorises all innovative activities that are not taken into account as hidden innovation. NESTA concludes that: "The importance of hidden innovation means that innovation policy needs to extend beyond stimulating scientific invention to include the adoption and exploitation of technologies, organisational innovation and innovation in services (including public services). As a result, innovation policy should encompass science and technology policy and not the other way around." (NESTA 2007 - Hidden Innovation Report)

It is interesting here to go back in time and examine NESTA's comment in the light of Nordic innovation policy and the underlying rationale stated at its very inception in 2004. A team of experts, lead by Per Koch, wrote in the publication GoodNIP and Innovation Policies in the Nordic Countries that:

"The NORIA white book was well received as far as its coverage of the university sector was concerned. However, the book is strongly focused on research as the driver of innovation and growth. As a matter of fact, the text barely goes beyond the world of basic research at the universities, and seems to be deeply embedded in the linear model” 35

Just as in the UK, the Nordic innovation policy debate still suffers from a linear model "hangover", and has only just begun to recognise the importance of users in innovation, open innovation and the service sector, together with the fact that innovation has many sources. R\&D represents only one of these sources, and it is usually not considered to be the most important by companies when they themselves are asked about their main sources of innovation. It is also worth noting that Denmark in 2007 was the first country to adopt a programme for user-driven innovation.

Another inspirational initiative is that of the US Dept. of Commerce's project "Innovation Measurement Tracking the State of Innovation in the

\footnotetext{
${ }^{35}$ Nordic Innovation Policies 2004, GoodNIP, p. 10, Norway, Oslo, 2004.
} 
American Economy - Measuring Innovation in the 21st Century Economy ${ }^{36}$ ". In the foreword it is stated that:

"With developing "new and improved measures of innovation" in three areas: how innovation occurs in different sectors of the economy, how it is diffused across the economy, and how it affects economic growth. While we recognize that the American economy is changing in fundamental ways-and that most of this change relates directly to innovation-our understanding remains incomplete. Indeed, data collection and measurement, while seemingly mundane, loom large in understanding these changes. Policymakers, investors, executives, managers, consumers, and researchers require accurate and complete information in order to make informed decisions. The centrality of the need to advance innovation measurement cannot be understated".

One of the goals of the Nordic Innovation White Paper was that Nordic innovation policy should support the growth of a leading, Nordic-based, international forum on policy expertise and analysis within the field of innovation policy. Good innovation policies depend on appropriate and reliable data and evidence in just the same way as good research depends on the generation of appropriate and reliable data. It is not clear to what extent current innovation indicators capture the reality of economic activities in the Nordic region. A future Nordic innovation policy might therefore play a useful role in developing co-operation with companies and organisations both within and outside the region in order to develop more relevant sets of indicators.

${ }^{36}$ A Report to the US Secreaty of Commerce by: The Advisory Committee on Measuring Innovation in the 21 Centry Economy, US State. Dep. Commerce, January 2008. 



\section{The Value Chain as the Innovation System}

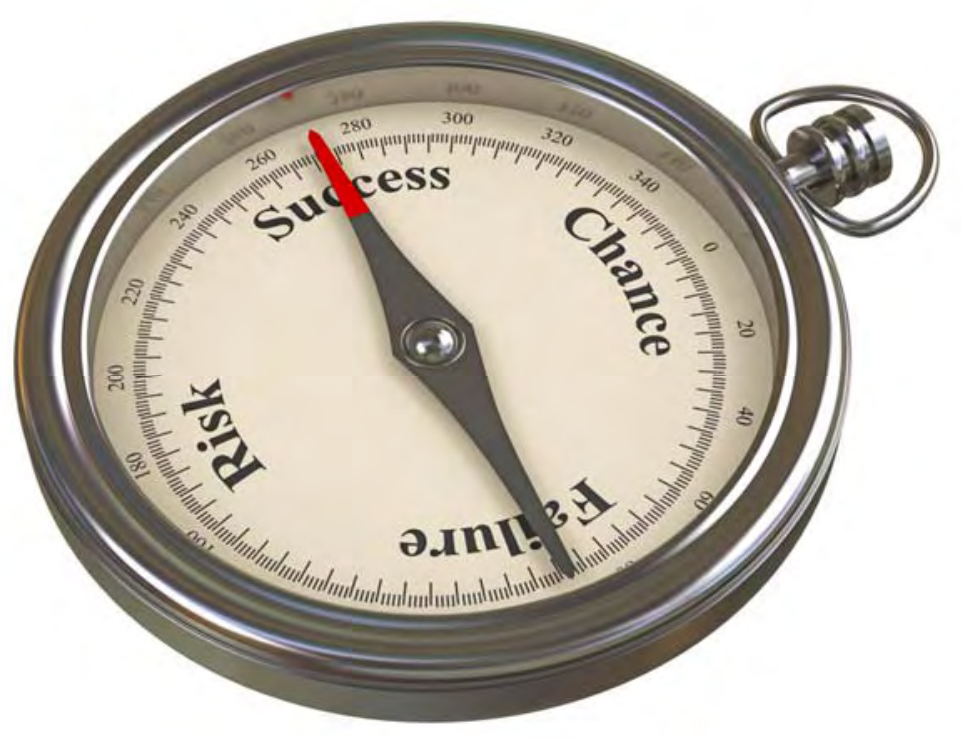


For the last 15 or 20 years innovation researchers and policy makers have adopted the habit of analysing innovation systems and of thinking about them from the point of view of the public sector institutions which are intended to support them. Innovation is about business. It is "done" by companies. It is a risky, collaborative, iterative, self-correcting activity that spans entire value chains, not individual companies, research labs or university departments.

And yet the research environment seems almost oblivious to this fact. A lot of work has been out on innovation policies, but relatively little on how the practice of innovation evolves. For example, if innovation is all about collaboration, then what is the nature of this collaboration? How are these collaborative efforts established? What skills are required? How can they go wrong, and what kind of support services might be useful? Finally, and from an organisational perspective, while tools such as portals, on-line market places, brokerage services and business-oriented social networking services become more widespread, how does the practice of innovation evolve, and what new opportunities and challenges will arise as a result?

A survey of the literature on innovation gives the distinct impression that the key players are not the companies and their supply chains, but universities and national research institutes. It is true that these institutions have a role to play, but such has to be seen in context. Large innovative companies such as IBM or Intel collaborate with between 500 and 1,000 universities and research labs located in most of the countries of the world. Merck carries out almost $12 \%$ of all research in the domains of interest to its business - possibly more than any single country. Companies are responsible for two thirds of research carried out in the world. Productivity and efficiency is important to such companies. They always need to do more for less. They not only carry out and source research, but also often administer their own corporate universities. These are amongst the largest learning systems in the world, involving as many as half a million people, including their own staff, together with the staff of their supply chain partners and small research teams dispersed among their hundreds of knowledge partners.

Innovation is organised and managed by professional corporate managers. It consists of many complex and risky inter-linked activities distributed across the value chain in large, dynamic networks. This view is 
useful because it reflects the reality in terms of how innovation appears from a business perspective. It is a very different picture than that we experience from a public research laboratory or public sector body, and arguably it should receive more attention from innovation researchers than has been the case in the past.

Companies such as Wal-Mart, P\&G and Intel play an active role in the development of innovation and entrepreneurship among their supply chain partners. They often collaborate with and invest in small enterprises operating in their sectors of interest. They provide market intelligence and orientation on customer needs. They provide access to tools and finance, support for marketing and distribution, and business service brokerage. These companies embody a wide range of models and philosophies for innovation support. Such models have so far received scant attention from innovation researchers. They can teach us a lot about the management and organisation of innovation.

It is quite natural for someone who is paid a salary to work all day in a lab, collaborating with his or her colleagues, to employ students to carry out development tasks as part of their study courses and avail themselves of the available space, raw materials and equipment, in the hope that some day they might discover something. Such requires dedication and flair, but discovery in this context is almost inevitable. However, this is not innovation. Innovation deals with finding a market and adapting the invention to the market in question. It sometimes involves solving hundreds of additional technical problems, most of which are difficult but of no great scientific interest. These constitute the essential success criteria.

Yet the issue of the market remains, and this is a problem of an entirely different kind. The questions of who will use the innovation and who will pay are often two entirely different matters. Who will make it? Who will distribute it and how? What will happen in the event of breakdowns or failures - when the product is returned, or when requests are made for modifications? For most researchers this is where the system falls apart. They can usually obtain assistance for the straightforward aspects of the process, but not for the subsequent stages. Amar Bhidé has 
interviewed several VC-backed start-up companies, of which one remarked that ${ }^{37}$

\begin{abstract}
"The way you sell enterprise software in Europe and Japan is not conducive to start-ups. You have to go through resellers and third-party channels. So you touch your customer much less. The customers themselves are often more risk averse and leery of adoption early stage technology from a small U.S. company.”
\end{abstract}

This story illustrates the point that the creation or invention of a technology or solution by an innovator is at best only half the battle. The real challenge to innovation is the second step. Real life examples illustrating how innovation is supported in the supply chains of major firms provides us with some clues as to how this can be tackled. The following examples are not exhaustive, but may serve to illustrate this new way of examining, analysing and understanding innovation systems.

Example 1: Intel is well-known for manufacturing micro-processors, and most people are familiar with the logo "Intel Inside". Much of the company's research and innovation activities naturally involve microchip design and production. However, the devices produced by Intel are deployed in a variety of different environments. As such they have to be designed in anticipation of specific user needs. These needs may be expressed in terms of levels of performance or speed, physical size, and energy consumption. The company must anticipate how they eventually will be used in applications such as servers, computers and laptops, supercomputer arrays, mobile phones, video monitors and games systems. For this reason Intel also carries out a great deal of research with the buyers of its chips and their customers in order both to correctly anticipate future needs and to demonstrate new applications. Intel also works with the software developers who write the code that makes the chip work in the purchasers' respective applications. The makers of electronic goods, together with the developers who provide the software and services that make them run, all play important and shifting roles throughout a series of multiple cycles of design, development and production that may continue for several years.

\footnotetext{
${ }^{37}$ Page 112 of "The Venturesome Economy - How innovation sustains prosperity in a more connected world" by Amar Bhidé published in 2008 by Princeton University Press, ISBN-13 978-0-691-13517-5.
} 
Naturally, Intel has its own suppliers. The companies that supply it with silicon and chemicals for its processes, combined with the companies that build the fabrication plants that package its chips, and those that handle transport, security and storage throughout the world. These suppliers are constantly under pressure to innovate in order to meet new targets in terms of functionality and performance, price and time to delivery. The specialised machines required to make the chips are constantly being redesigned in order to be able to adapt to successive generations of technology. The plants are complex and must be managed. This is accomplished by software, some of which is developed in-house, while the rest may be sourced externally. Waste must be recycled or disposed of. There is an ongoing process to reduce environmental impact and financial costs. All of these activities are constantly being improved. Every single day involves thousands of problems of varying size and complexity, all of which have to be solved. Most will have many possible solutions. This means that choices, trade-offs and decisions have to be made. This situation represents the real context in which innovation happens. We have used Intel as a reference here, but similar scenarios are also emerging in other sectors, notably in the manufacture of engines and motors, games software, and in the media, foodstuffs and catering sectors.

Intel supports a variety of online communities and maintains links with over 1,000 universities around the world. It has developed a partner programme designed to assist SW developers in keeping up with its everevolving hardware products, and to help them align their development plans with those of Intel. The programme also helps them access the tools they need to develop the SW that will run on Intel hardware, and to facilitate business networking via its partner catalogue. It also helps to facilitate sales of the SW via Intel BX, which is the company's proprietary business exchange. ${ }^{38}$ The SW partner program has three main components:

Firstly, a planning component which is aimed at executives and business decision-makers and which provides access to technology road maps.

Secondly, a development component, which is aimed at engineers and technology decision-makers and which provides access to support for development projects, together with access to developer tools, libraries and training opportunities.

\footnotetext{
${ }^{38}$ http://www.intel.com/cd/software/partner/asmo-na/eng/index.htm
} 
Thirdly, a "Go-to-Market" component, which is aimed at marketing and sales executives, and which provides access to the use of Intel logos, case studies, catalogues and certification programs, together with tools for planning marketing campaigns and sales support via the Intel Business Exchange.

This description covers just the SW partner system. For example, other partner systems are oriented towards specific types of hardware or towards basic research. Intel also operates a venture capital arm that invests in companies operating in businesses where it sees a synergy and opportunities to play a constructive role in assisting business growth. This is not simply a system for supporting innovation and development for Intel' own sake, but for the many companies that gravitate around it and which participate in the sectors in which it is involved.

Example 2: P\&G operates hundreds of manufacturing plants around the world, together with a vast network of sales channels and retail testsites, and specially trained teams armed with the ability to observe consumers and understand their unmet or as yet unarticulated needs. These have been documented in many recent books and articles, but most informatively by their $\mathrm{CEO}^{39}$ P. J. Lafley himself. The company has adopted an open innovation model in which it aims consistently to source more than $50 \%$ of its new product concepts from outside the company. It offers itself as a platform for entrepreneurs developing new consumer goods and has thus positioned itself as the partner of choice for innovation companies developing new ideas for commercial domains in which $P \& G$ is active. In effect, the company is offering itself as a platform for the commercialisation of ideas, innovations and market insights that originate elsewhere.

P\&G's vision ${ }^{40}$ is "to be known as the company that collaborates better than any other company in the world." They have 28 R\&D facilities on four continents focusing on 150 areas of science and technology. The dompany has accumulated know-how and experience from the development, manufacture, launch and distribution of more than 300 brands in more than 160 countries. It conducts more than 10,000 consumer research studies every year. P\&G offers itself to smaller businesses and entrepre-

\footnotetext{
39 “The Game Changer - How Every Leader can Drive Everyday Innovation” by P. J. Lafley and Ram Charam, published by Profile Books Ltd in 2008, ISBN 978-1-84668-162-2.

${ }^{40}$ http://www.pg.com/en_US/index.shtml
} 
neurs as a platform-for-innovation all over the world. In the spirit of open innovation the company collaborates on new products and services, on $\mathrm{S}+\mathrm{T}$ research, market research, packaging, design, manufacturing, distribution and new business model deployment. External Business Development ${ }^{41}$ at $P \& G$ is based on two main programmes, named "Connect and Develop" ${ }^{42}$ and FutureWorks ${ }^{43}$.

The P\&G Connect and Develop programme is well-known by now, having served as the open innovation icon for many innovation writers and commentators. It supports collaboration between P\&G and the wider world on scientific and technical problems. It is a two-way street in that it supports both the sourcing of solutions to existing problems and challenges faced by $P \& G$, while at the same time offering solutions to outside parties based on underused IP assets created by P\&G itself.

In contrast, the aim of FutureWorks is to generate new entrepreneurial business. It can help to transform fledgling external businesses that currently serve new markets into scaleable mass market enterprises. It also helps to leverage the $P \& G$ brand portfolio into new and related products and services. It has a strong interest in the services sector. A good example of what this means is given by the Mr. Clean Auto-Spa ${ }^{44}$ franchise. Mr. Clean is well-known as a P\&G brand for household cleaning products. The Mr. Clean Auto-Spa uses this brand as a marketing platform to promote a low-cost, environmental and user friendly car wash service. The company offers a wide range of services in line with the concept of a Spa for cars. The basic hand-wash service takes as little as 15 minutes, uses less than 16 ounces of water and recycles dirty water and detergent. The services is based on P\&G bio-degradable or environmentally friendly cleaning products, and the customer can enjoy a coffee while they are waiting.

Furthermore, strategies to leverage the company's hard-to-reproduce assets don't stop there. P\&G also runs a B2B exchange to support the sourcing needs of its partners. One of its internal market research divisions has developed a network of 250,000 teenagers and 450,000 mothers who take part in word-of-mouth marketing programmes. These programmes were

\footnotetext{
${ }^{41}$ http://www.pg.com/b2b/pg_external.shtml

${ }^{42}$ https://www.pgconnectdevelop.com/pg-connection-portal/ctx/noauth/PortalHome.do

${ }^{43} \mathrm{https}: / / \mathrm{www}$.pgconnectdevelop.com/pg-connection-portal/ctx/noauth/ 0_0_1_4_83_4_10.do

${ }^{44}$ http://www.mrcleancarwash.com/about_us.html
} 
initially developed by the P\&G Tremor division to promote its own P\&G brands. This service is now offered to external clients ${ }^{45}$.

Example 3: Amazon is primarily an online retailer. Its original focus was on books, but it now sells music and films, clothes, shoes and consumer electronics. You may have noticed that many of the books you currently available via Amazon do not necessarily originate with the company. They may be either second-hand or are provided by other publishers and distributors. Having built up an infrastructure for online sales, warehousing, distribution and payment, Amazon now offers this as a platform to other companies as a support for their retail activities. It has diversified from being purely a retailer to becoming a provider of retail infrastructure that can be utilised by smaller firms. This represents a major innovation in that Amazon now acts as an enabler of other retailers who can now avail themselves of the global retail and distribution infrastructure that it has already built.

Large companies that have built up assets such as technology platforms, brands, sales channels and processes are now finding ways to transforming these assets into saleable services. Assets such as business networks, retail and distribution channels are complex, sticky and hard to reproduce. Having made their investments and learned how to provide a service to meet its own internal needs, companies are finding ways to make these available to external parties.

Different companies have different styles and different philosophies and approaches to supporting innovation. It is worth noting that WalMart, which became famous for the way in which it applied price pressure to its suppliers in order to lower the cost of the product to the consumer, has embarked on a green crusade and is currently applying pressure to increase the resource efficiency, lower the energy consumption of otherwise reduce the environmental impact of the product ${ }^{46}$. The Toyota group is a highly diversified conglomerate that incorporates subsidiaries dealing with a variety of businesses such roof gardens, sustainable forestry and the recycling of manure from dairy cows. There are many other examples worth studying, including Google and Nokia, Ikea, Lego and StatoilHydro, to name but a few.

\footnotetext{
${ }^{45}$ http://www.pg.com/b2b/pg_tremor.shtml

${ }^{46} \mathrm{http}: / /$ walmartstores.com/Sustainability/
} 
Contemporary discussions on open innovation by authors such as Henry Chesbrough ${ }^{47}$ tend to emphasise the role of patents and other highlevel forms of knowledge, together with the emergence of secondary markets for intellectual property in the form of patent portfolios. This is an important phenomenon, but it only represents a part of what leadingedge companies are now doing to leverage their intangible assets. The range of such activities now covers:

- Scientific and technical problem-solving

- Brand development, especially in the service sector

- Business development in partnership with high growth potential companies

- Procurement of general business services via its B2B exchange

- Provision of high value-added business services such as word-ofmouth marketing via its Tremor Division.

This discussion is intended to act as a motivation to support the following proposals regarding future research on innovation in the Nordic countries:

- Support research on the structure and dynamics of corporate innovation systems, the means by which they support innovation, and the extent to which these systems can be harnessed by small companies and newcomers operating in the sector.

- Understand how companies that have created intangible assets closely incorporated within their internal services or embodied in the business networks to which they belong, have started to use these assets as sources of additional income and as platforms for supporting both inhouse innovation and the entrepreneurial initiatives of external firms.

- Examine how to help large corporations that have not yet developed such systems to consider this as a potential path for future progress. Understand how to help indigenous national companies harness these assets. Explore how such assets could be exploited by smaller companies as the private component of a domestic innovation system.

\footnotetext{
${ }^{47}$ Author of "Open Innovation: The New Imperative for Creating and Profiting from Technology” published in 2003 by Harvard Business School Press, ISBN-13: 978-1578518371, and “Open Business Models: How to Thrive in the New Innovation Landscape” published in 2006 by Harvard Business School Press, ISBN-13: 978-1422104279
} 



\section{Encouraging Entrepreneurship}

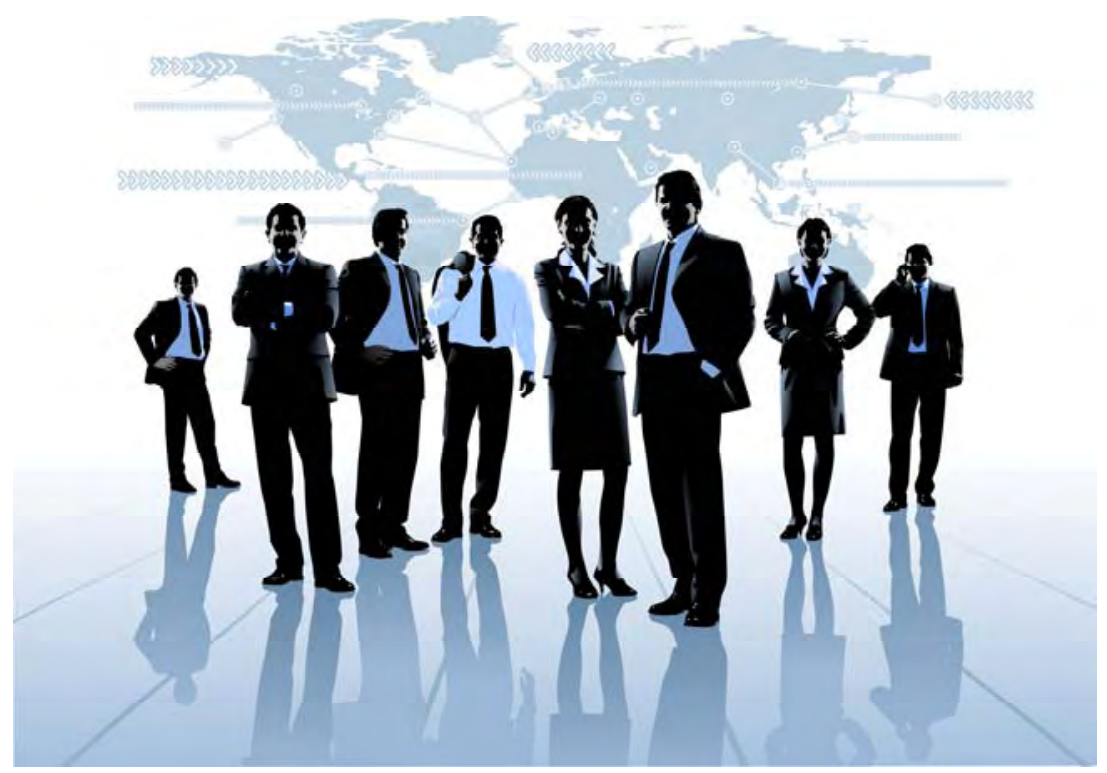


Innovation and entrepreneurship are two sides of the same coin. If innovation represents what needs to be done, then entrepreneurs are the people who make it happen. Joseph Schumpeter identified entrepreneurs, whether in large firms or small ones, old companies or start-ups, as the agents of innovation and creative destruction ${ }^{1}$. In a nutshell entrepreneurship represents the human dimension of innovation. The entrepreneur deals not only with the intellectual aspect of innovating - she or he also has to carry out the day-to-day organisation and management tasks. It is often hard to identify an entrepreneur because nobody is an entrepreneur all of the time, and nobody is ever "only" an entrepreneur.

Schumpeter drew an important distinction between invention and innovation, and thus between inventors and entrepreneurs. He writes; "The making of the invention and the carrying out of the corresponding innovation are economically and sociologically, two entirely different things [...] often the two interact, but they are never the same, and innovations are usually more important that inventions [...] only confusion can result from focusing on inventions instead of innovations" ${ }^{2}$. He pointed out that the task of innovation requires much more than technical invention. Innovation in the case of soap, for example, represented not simply the task of manufacturing soap but also that of inducing people to wash. This is a problem of an entirely different nature. It requires just as much creativity as the original formulation of soap and the invention of a process by which to make it. Ultimately, innovation succeeds not when it produces new things but when it changes the behaviour of users or consumers and the entire whole range of vested interests to which they are affiliated.

In view of the recent interest in "open innovation", and in the light of efforts, described elsewhere in this paper, of major companies to harness the energy and talent of entrepreneurs outside and inside a given company, entrepreneurship should not be identified with intrapreneurship. To do so would be to ignore the newest and currently most relevant dimensions of the issue. The most innovative companies try to harness the energy and talent of entrepreneurs whereever they are found. Schumpeter recognised that much of the success enjoyed by individual entrepreneurs resulted from their talent for seizing the opportunities of the moment, and that the main challenge for the innovator was to overcome the extreme difficulty of changing traditional ways of doing things. ${ }^{3}$ An important 
factor in successful entrepreneurship is the ability to overcome these difficulties. In this sense entrepreneurship is a form of leadership.

George Buckley, the Chairman, President and CEO of 3M, recently summed-up the issue when he spoke to an advisory committee of the US Department of Commerce which was considering the measurement of innovation in the 21st Century ${ }^{4}$. As part of his discussion dealling with international competitors in emerging economies such as Brazil and China, he said; "We need access to talent [...] our competitors can just about invest as much as we can in manufacturing plant [...] as much in marketing as we do [...] even as much in technology as we do [...] in the end the only thing that separates the best from the rest are the people you hire”. Few would disagree, but the real issue is what kind of talent?

The ability to identify and evaluate useful knowledge and sources of knowledge, to evaluate these sources as partners, to integrate them into a disciplined innovation process, to design, manage and adapt this process, are all fundamental to innovation success. This is just as important, and maybe even more so, than the ability to perform research ${ }^{5}$ or execute targeted development tasks. Peter F. Drucker formerly emphasised that innovation is a discipline that can be learned and practiced, and that there are basic principles that can be followed. He also maintained that this holds true for entrepreneurship - the work of those who make innovation happen ${ }^{6}$ This view was borne out by A. G. Lafely when he related how he transformed P\&G into an innovation machine ${ }^{7}$. He described innovation as a social process that can be formalised, and for which employees can be prepared and developed. He says that;

"When you as a leader understand this, you can map, systematize, manage, measure and improve this social process to produce a steady stream of innovations [...] innovation is not a mystical act; it is a journey that can be plotted, and done over and over again. It takes time and steady leadership [...] but it can be done."

Back in 1985, Drucker recognised that innovation needed to be organised as a systematic activity, and that business itself needs to be organised in order to evolve as a successful innovator. He realised that this requires the dual disciplines of innovation and entrepreneurship. He considered the latter mainly to represent the process of making innovation work in the market place ${ }^{8}$. 
Ultimately, business models rely on both a technological and a social architecture. This social architecture is intimately linked to the human resource function of the firm, and corresponds to a form of knowledge that is deeply tacit and not easily reproducible by other companies. Entrepreneurs tend to be good at understanding and manipulating social architecture. Whereas inventors are good at solving technical problems, entrepreneurs have to be good at solving social ones. It is useful to examine a specific example to see exactly what is meant by this.

Innovation in medical devices is a highly collaborative process that takes place when engineers work together with those responsible for clinical care. This involves co-operation not so much in the design of the device but in terms of understanding how it needs to be applied. Nurses and those involved in after-care can play a key role in this process. The surgeon is only involved with a patient during an operation, whereas the nurses are involved both before and afterwards. They observe the longerterm effects and impacts on the patient during and after recovery. They often have a detailed understanding of the entire patient cycle from admission to diagnosis, treatment and recovery. However, working with nurses can be very difficult because surgeons represent the senior profession and may put their needs ahead of both patients and other staff at the hospital. Examples abound situations involving technical innovations in the remote monitoring of patients in intensive care, where physicians have obstructed progress.

This underlines the challenges faced by entrepreneurs who need successfully to navigate a variety of social situations and overcome resistance to change. Innovation is a social process as much as a technical one. After first having gained access to technologies that work, there is a subsequent need to overcome the barriers thrown up by people who view innovations as threats to their activities and then react defensively. These people are often employees, customers and competitors. This kind of problem solving receives scant attention in research on innovation. Excessive focus on the technical development of a system distracts the researcher from the major component in the picture. The staff also represents a part of the system and until issues related to personnel and their relative abilities and willingness to go along with change are addressed, it will not be possible to understand the innovation process or succeed as an entrepreneur. 
A. J. Lafley, the CEO of P\&G, emphasises the ability to collaborate. He says that "Innovation leaders are comfortable with uncertainty and have an open mind; they are receptive to ideas from very different disciplines. They have organized innovation into a disciplined process that is replicable. And, they have the tools and skills to pin-point and manage the risks inherent in innovation. Not everyone has these attributes. But companies cannot build a culture of innovation without cultivating people who do"9.

He mentions "leadership". This is significant because leadership and entrepreneurship are two important aspects of innovation. It used to be thought that leaders were born, but now we know better and actively strive to develop leaders and leadership skills. Alan Todd, Chairman of the Board of US-based CorpU claims that the overwhelming majority (about 90\%) of large global enterprises do not have the leaders they need to remain competitive. Seventy per cent of these feel that current approaches to identifying and developing leaders are inadequate. This represents a clear call for further innovation in the development of human resources, especially for the public sector.

These issues are given very little attention in modern approaches to innovation. In many ways, such approaches align innovation with research or invention, and fail to understand it as the basic process driving change in business. A lot of effort goes into the development of engineers and research in innovation, but relatively little into the all of these other "hidden" issues that are essential to the innovation process.

A key issue for both society and industry today is how to identify, develop and facilitate an environment that will support entrepreneurs - that allows them to thrive and which enables them to "up their game”, improve, and achieving more than if they were simply left to their own devices. This issue was addressed in the NICe-funded "NordTrend" project as part of which a 4-stage stage classification of companies was made categorising them in terms of the environment they provide for entrepreneurship ${ }^{10}$. Under this classification, a company will belonging to one of four main types:

The opportunist is a company that adopts a diffuse and ad hoc approach to supporting entrepreneurship. 
The advocate is a company where top management advocate innovation but where there is no enterprise system to support entrepreneurs. Responsibility and funding tends to reside at the level of the business unit.

The enabler is a company that invests substantial resources in entrepreneurship in terms of finance and senior executive support. This approach mode is based on the premise that employees throughout the organisation will be willing to develop new concepts if they are giving adequate support.

The producer is a company that establishes a full-service group with a mandate for corporate entrepreneurship ${ }^{48}$.

As our understanding of entrepreneurship improves, a need may develop to improve upon, extend or otherwise revise this classification. However, until then much can be gained by applying such schemes to populations of companies to assess their overall standing. The following diagram summarises the results of a pilot study using a sample of companies carried out earlier this year ${ }^{49}$.

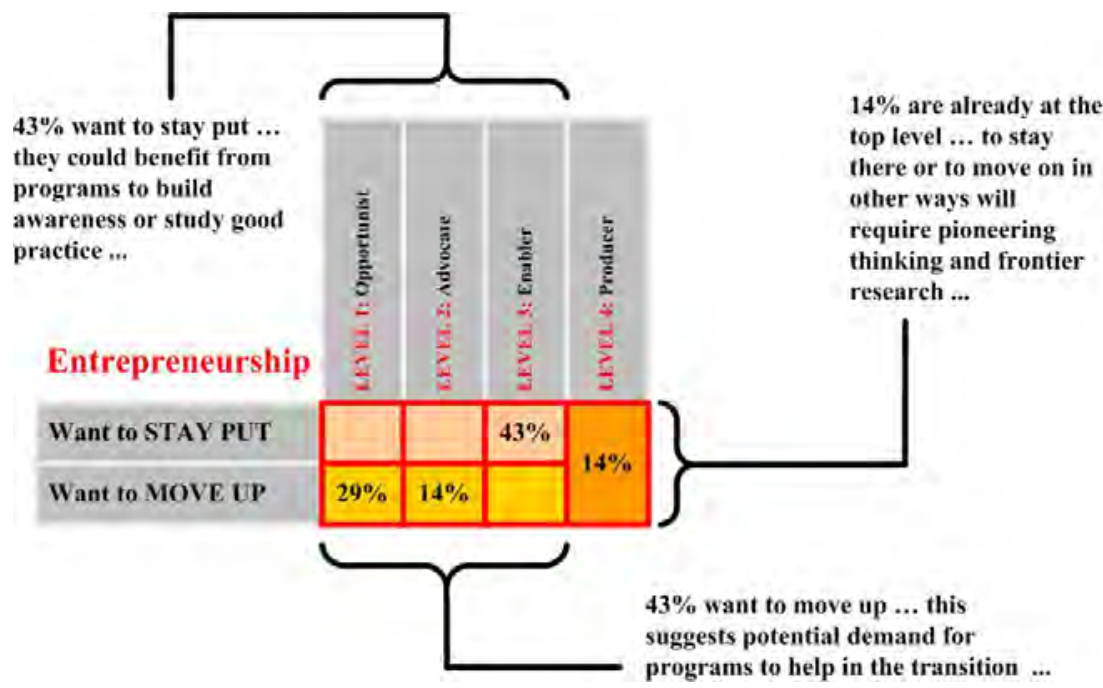

${ }^{48}$ Robert C. Wolcott and Michael j. Lippitz: The Four Models of Corporate Entrepreneurship. MIT Sloan Management Review, Fall 2007, Vol. 49 No. 1

${ }^{49}$ Nordtrend - Patrick Crehan, A Nordic Innovation Center project: publication forthcoming 2009 


\begin{abstract}
Although it is qualitative and subjective, feedback of this sort provides those involved with innovation and entrepreneurship with a view of the overall ability of industry to organise and manage entrepreneurship on a sector-by-sector basis. Companies were asked where they stood today and where they wanted to be in 3 years time. The results pointed to a range of services that companies might require as well as the potential level of demand. This approach to measuring entrepreneurship provides feedback that is both meaningful and actionable for government and for individual companies. Future projects conducted by Nordic innovation could investigate this further and broaden the scope in order to provide a diagnostic of innovation-related company capabilities on the scale of the entire Nordic economy.
\end{abstract}





\section{Conclusions}

The Next Big Thing? Future Trends Shaping Nordic Innovation is not a crystal ball revealing all that we can expect to happen during the next five to ten years and beyond. It is more of a description of some of the important driving forces and developments which are likely to shape events both globally and in the Nordic region. The array of driving forces highlighted here is by no means exhaustive. The article could equally well have focused on critical technologies such as cloud computing or the role of Soverign Wealth Funds in the fields of global investment and competition.

This publication is intended to provide input to the discussion surrounding, and the formulation of, the Nordic countries' next generation of innovation policies.

In Chapter One, under the heading; "New modes of globalisation" we looked at how emerging economies such as India, China and Brazil, together with certain African countries, are changing the global economic landscape. Western Europe and the US dominated global economic affairs for more than 200 years, but this is no longer the case. China and India in particular are challenging this position with a combination of extensive access to talent, huge domestic markets, and an ingenuity for the development of new concepts and products which are adapted to both the "base-of-the-pyramid" (people with very limited financial means), and to the more affluent global export markets. In the words of Philip Kotler, we are embarking on a new chapter in global economic history, as part of what Freed Zakaria calls "the rise of the rest".

In Chapter Two, titled "Leverage of Innovation Hot-spots" we examined how access to specific knowledge has become an issue linked to the siting of enterprises in global hot-spots that match perceived needs. The Nordic countries have been pioneers in the establishment of innovation service centres in global hot-spots such as Silicon Valley and 
Shanghai. However, this chapter also argues that the scope of the concept of a global hot-spot must be broadened, and that social communities such as Facebook should also be included together with the "baseof-the-pyramid" communities in poorer countries.

In the chapters "Services and Innovation" and "Open Innovation" we looked at the service economy and innovation. For about 20 years Europe and the Nordic countries have regarded manufacturing and high-end services such as research and innovation as separate entities. This is best illustrated by the prevailing belief in outsourcing as many manufacturing actitivities as possible to countries such as China, while at the same time retaining high-end professional services in the domestice environment. However, the interlinkages between manufacturing and the service sector are rather complex. It is by no means always clear at which point in the value chain these sectors can be distinguished, while at the same time retaining their competitiveness. Several examples are used to illustrate that a more comprehensive perspective will lead to winning business models in the competititive global economic environment. Throughout history, winning business models have often been anchored in superior management techniques. These two chapters provide an outline of how management models have radically transformed entire industries, and yet such models are not accounted for in current measures using innovation indicators. As regards open innovation it is still too early to say if it this will play a major role in shaping modern managment in the same that scientific management or divisionalisation has done in the past. However, open innovation is a promising concept, and constitutes a model that will have profound impact on future management practices in general.

In the chapter headed "Innovation Indicators" we described how the current trends in understanding global economic competition are based, at best, on flawed and, in the worst case, directly misleading indicators. Current industrial indicators are to an increasing extent failing to tell the whole story about what actually goes on within the major segments of the developed economies such as we find in the Nordic and OECD countries. No account is given of the service sector or of innovative activities in particular. The Nordic countries are, together with the US and the UK, among those looking into how to develop more appropriate statistical indicators for understanding what is going on within our economic systems. 
In the chapter entitled "The Value Chain as an innovation system" we looked into how leading global companies from different industrial sectors manage and operate innovation based on their profound understanding of where the locus of innovation resides within their industries. In a rapidly changing global economy, the locus of innovation in any given value chain is also in a state of flux. Failure to understand these changes can be fatal for a company's chances of survival, and innovation policies should reflect this.

In the the chapter headed "Encouraging Entrepreneurship" it was argued that entrepreneurship is the life-blood of a free enterprise society and that innovation and entrepreneurship are two sides of the same coin. It was also argued that entrepreneurship today has little to do with the often popular image of the solitary inventor in his garage. On the contrary, entrepreneurship can take place both within and outside an organisation, and companies which promote in-house entrepreneurship (intrapreneurs) will often display high levels of innovation performance.

The final chapter of this publication, which follows this conclusion, focuses in particular on "Climate Change - Impacts for Nordic Industry, Technology and Innovation". The chapter served as the basis for a discussion and panel representations at Iceland's session during the Nordic Climate Solutions conference held in Copenhagen on 7-8 September 2009. 



\section{Special Focus: Climate Change - Impacts for Nordic Industry, Technology, and Innovation}

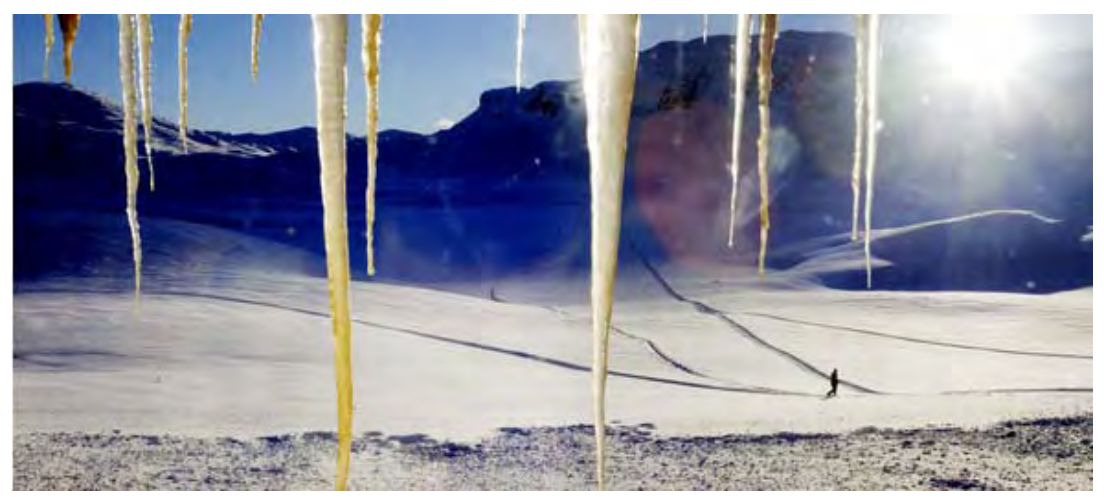

Photo: Karin Beate Nøsterud/Norden.org

Presented at the conference: Nordic Climate Solutions, Iceland's session Copenhagen 7 \& 8 September 2009.

Authors:

Patrick Crehan, Ph.D, CEO Crehan, Kusano \& Associates

\&

Jørn Bang Andersen, Senior adviser innovation

Nordic Innovation Centre, Nordic Council of Ministers 


\section{The challenge and what is at stake}

Arguably the first attempt by a major national government to understand climate change and the urgency of addressing it, was a UK government review $^{50}$ lead by a former chief economist of the World Bank, Sir Nicholas Stern, and released in October 2006.

The Stern review explained that the main cause of climate change was the emission of greenhouse gases arising from the burning of fossil fuels and activities related to land-use such as deforestation and agricultural production. It explained that actions taken over the next 10 to 20 years would have a profound effect on climate in the second half of this century and into the next. It made headlines when it published a conservative estimate stating that if not addressed, the overall cost of climate change to the global economy would be equivalent to a drop in global GDP of 5\% per annum each year, now and forever. Taking into account a wider range of risks and impacts, it estimated that the costs and damages could rise to over $20 \%$ of GDP per year. The good news however was that if action were taken in time to reduce greenhouse gas emissions and avoid the worst impacts of climate change, the impact could be limited to around 1\% of global GDP per year. The review called for concerted efforts on behalf of all nations to take immediate action to avoid disruption to economic and social activity on a scale similar to that experienced due to the great wars and the economic depression of the first half of the 20th century.

The Stern review indicated that while it would be difficult to avoid an increase in concentration of greenhouse gases to double pre-industrial levels by 2035 leading to a global average temperature rise of over $2^{\circ} \mathrm{C}$, the long-term effect of inaction would be a temperature rise in excess of $5^{\circ} \mathrm{C}$, equivalent to the change in average temperature from the last ice age to the present day.

The IPCC $^{51}$ agrees that a rise in average surface temperature of the planet by as little as $2^{\circ} \mathrm{C}$ above pre-industrial levels will have serious consequences for nature, society and the global economy due to dangerous and unpredictable climate change associated with such a rise in temperature.

\footnotetext{
${ }^{50} \mathrm{http} / / / \mathrm{www} \cdot \mathrm{hm}$-treasury.gov.uk/sternreview_index.htm

${ }^{51}$ http://www.ipcc.ch/
} 
The Nordic countries have independently verified these findings. A study commissioned by the Nordic Council of Ministers and carried out by CICERO, the Oslo-based Centre for International Climate and Environmental Research ${ }^{52}$ and COWI of Denmark, entitled "The Nordic region will feel the heat", examines the impact of a $2^{\circ} \mathrm{C}$ rise in temperature by $2100^{53}$ on the natural environment in terms of phenomena such as sealevels, snow and ice, the warming of the arctic region and the extinction of species, together with the impact on industrial sectors such as agriculture, forestry, fishing, energy and tourism. The impact is dramatic and it looks in-creasingly likely that this estimate may be too conservative.

In February 2009 MIT News ${ }^{54}$ reported findings of a team of scientists at MIT indicating that:

"warming could be double previous estimates" and that this “... increases the urgency for significant policy action.”

Their latest estimate suggests that surface warming of the Earth by 2100 will lie between $3.5^{\circ} \mathrm{C}$ and $7.4^{\circ} \mathrm{C}$ with $90 \%$ probability. This corresponds to an expected rise of $5.2^{\circ} \mathrm{C}$ rather than $2.4^{\circ} \mathrm{C}$ indicated by previous studies. Other studies seem to support this view. The EDGAR ${ }^{55}$ project for monitoring global man-made emissions has recently reported that emissions are growing much faster than anticipated. They find that the increase from $2000-2005$ is about $15 \%$ whereas the increase from 1990 to 1995 was only $3 \%$. The consequences of not implementing climate change policies may be even more dramatic than their work indicates.

The prevailing opinion among scientists is that to limit climate change to less than $2^{\circ} \mathrm{C}$ by 2100 , it will be necessary to implement measures that ensure among other things a reduction of $60-80 \%$ of 1990 levels of greenhouse gas emissions by 2050. This forms the basis for discussions on binding targets and many countries and cities have made legally binding commitments to achieving targets by 2020 an 2050 . These targets are very important for innovation, because without them there is no level playing field

\footnotetext{
${ }^{52}$ http://www.cicero.uio.no

${ }^{53}$ http://www.cowi.com/menu/news/newsarchive/nature/Pages/ thenordicregionwillfeeltheheat.aspx

${ }^{54}$ David Chandler, MIT News Office 19 May 2009 http://web.mit.edu/newsoffice/2009/roulette-0519.html

55 The European Database for Global Atmospheric Research at http://edgar.jrc.ec.europa.eu
} 
and companies that eschew investment in new technologies to achieve these targets may gain short-term advantages over those who do not.

The Stern review led to the creation of the Office of Climate Change in the UK, which has in turn been upgraded to the Department of Energy and Climate Change ${ }^{56}$. Since then many governments and international organizations have conducted their own independent assessments of the impact of climate change, and they have subsequently put in place structures and measures to address what is now seen as one of the most important challenges facing humanity today.

The IPCC $^{57}$ won the Nobel Peace Prize in 2007 along with Al Gore for its efforts to disseminate knowledge about climate change and encourage measures to counteract such change. Al Gore made a significant contribution to communicating the dramatic effect of global warming on the natural environment and the fact that we are already experiencing climate change in dramatic ways in his film "An Inconvenient Truth". Other initiatives such as the "Planet under Pressure" series for TV produced by the BBC continue to develop this theme.

More than 190 countries have now signed the UN Framework Convention on Climate Change ${ }^{58}$. This recognizes that the climate system is a shared global resource and sets out a framework for inter-governmental efforts to tackle the challenge. Climate change is now a key item on the political agenda of all advanced industrialized countries. The trend is to see this as an opportunity for new business and job creation and to address not only a defensive approach aimed at limiting costs and climate change, but also the creation of new jobs and growth on the basis of the new technologies, new industries and the services they will require.

The transition to a low-carbon economy is an important component of U.S. economic recovery in the wake of the recent financial crisis. Some estimate that the transition provides an opportunity to create over 5 million new jobs in the coming years in the US alone ${ }^{59}$, and many business analysts believe that the economic leaders of tomorrow will be the companies that manage their resources efficiently and take the lead in devel-

\footnotetext{
${ }^{56}$ http://www.occ.gov.uk/

${ }^{57}$ www.ipcc.ch ... International Panel on Climate Change

${ }^{58} \mathrm{http}: / /$ unfccc.int/2860.php

${ }^{59}$ See The Council on Competitiveness, Energy Security, Innovation \& Sustainability Initiative and Harvard

Business Review, “Forethought: Climate Business, Business Climate,” October, 2007.
} 
oping and commercializing innovative clean technologies ${ }^{60}$. The EU has responded with a raft of mutually reinforcing policies and initiatives called the "Climate and Energy Package". These include the SET-Plan for Strategic Energy Technologies ${ }^{61}$ and the EU-ETS system for trading carbon to which all Nordic countries belong ${ }^{62}$. In many ways this represents a global race to occupy "green space" in what is seen by many as a new industrial revolution.

Sweden played an important role in setting the agenda at EU level when it hosted the Summit of European Ministers in Gothenburg in 2001. It put forward a vision of a sustainable Europe by 2030 that is now shared by all the EU member states and is commonly referred to as "The Gothenburg Agenda". Norway has identified limiting the rise to less than $2^{\circ} \mathrm{C}$ as one of its major policy priorities for the future. Denmark will host COP15, one of the most important ever global events on climate change in Copenhagen from 7-18 December ${ }^{63}$ this year. The transition towards a sustainable growth model has gained considerable political momentum and Nordic countries are well placed to provide continuing leadership by demonstrating to the world how to achieve this goal.

\section{Climate and energy}

The main cause of climate change is the emission of greenhouse gases from the burning of fossil fuels. This is why strategies to address climate change are for now primarily formulated in terms of energy. The measures taken include measures to encourage:

- Increased energy efficiency by private and industrial consumers

- Increased use of renewable energy sources

- Smarter two-way distribution systems, connected across national borders

- Reduction of emissions, e.g., via carbon capture and sequestration

\footnotetext{
${ }^{60}$ See The Council on Competitiveness, Energy Security, Innovation \& Sustainability Initiative and Harvard

Business Review, "Forethought: Climate Business, Business Climate,” October, 2007.

${ }^{61}$ http://ec.europa.eu/energy/technology/set_plan/set_plan_en.htm

${ }^{62}$ The EU-ETS http://ec.europa.eu/environment/climat/emission/index_en.htm

${ }^{63} \mathrm{http}: / / \mathrm{en} . \mathrm{cop} 15 . \mathrm{dk} /$
} 
Peter Drucker pointed out that "every social and global challenge of our day is a business opportunity in disguise". ${ }^{64}$ Far from being a burden, the transition to a low-carbon economy should be seen as an opportunity for business in sectors where the Nordic countries already have an edge.

Each Nordic country occupies a strong position in one or more areas of renewable energy production. In Iceland it is geothermal energy, in Norway it is hydro- and solar power, in Finland bio-energy from wood, whereas wind power dominated in Denmark, and hydropower and the use of solar panels in Sweden. These positions of strength provide strong arguments for foreign direct investment in the Nordic countries, especially for the re-location of energy intensive industries from regions with a high climate footprint to regions where it is much lower. There has already been some migration of businesses relying on computer centers, to areas where the climate is colder, where cooling can be achieved by using locally-derived air, water or ice rather than by energy intensive methods.

The Nordic countries already have a significant position in areas such as wind-energy, solar and geothermal power as well as bio-fuels derived from trees and bio-gas derived from agricultural, industrial and domestic sources of organic waste. This is guided by a vision of the future in which in principle all houses and buildings become both producers and consumers of energy, drawing from and feeding into smart electricity networks, where most energy is produced locally from a mixture of different sources, and where many tasks that once required energy from the grid are carried out using direct approaches to heating, drying and cooling. This last issue is very design intensive and provides challenges for architects and urban designers and not only for engineers working in the energy sectors.

Most electricity in Norway comes from hydro-power and is therefore carbon-neutral. However, Norway is a major producer of oil and therefore has an interest in technologies for carbon-capture and storage. Developments in this area could provide many benefits in terms of climate change mitigation. It has been known for a while that some rocks have a voracious appetite for carbon and readily absorb carbon dioxide. Geologists have known for some time that when peridotite is exposed to

\footnotetext{
${ }^{64}$ In a conversation with David Cooperridge in 2003 reported in the article available at http://www.aacsb.edu/publications/Archives/JulAug08/32-39\%20Sustainable\%20Innovation.pdf
} 
the air it can react quickly with carbon dioxide to form carbonates such as limestone or marble. Some scientists have observed that natural outcrops of peridotite in places like Oman absorb considerable amounts of atmospheric carbon. They believe that it is possible to increase the rate of absorption by a factor of up to 100,000 times or more and that this process could be used to capture carbon on a scale that would have a significant impact on climate change. Of course it is early days yet, but some scientists harbour hopes that volcanic basalt in Iceland could be used for the same purpose. This is an example of where research may be required to investigate climate technologies that could provide a significant return in the long-term.

Nordic Energy Research has carried out studies to develop NORIA the Nordic Research and Innovation Area ${ }^{65}$. This work includes a series of Nordic Energy Perspectives on issues such as district heating, energy imports, renewables and electric cars. It includes studies on the national energy innovation systems of the Nordic countries and on the international dimension of research cooperation with countries such as Russia and China. The main focus is on research and on the commercialization of projects developed within the publicly funded research program. A broader innovation agenda needs to be developed however - one that goes beyond transferring technologies from the lab and into the field to leverage existing capabilities, not only for the Nordic but also for other world markets. The newly established (2008) Top Reserach Initiative established by the Nordic Council of Ministers with NordForsk, NICe and Nordic Energy Research deals with several of these questions.

Binding targets for the Nordic countries in terms of renewable energy production and greenhouse gas emissions, whether at national or city level, are ambitious, and all available solutions should be considered. There is a tendency only to promote the results of public research projects, but this is to ignore most of what is available at any given time. McKinsey Consulting has identified 250 technologies for the reduction of greenhouse gases in the US ${ }^{66}$ alone. It points out that $80 \%$ of these are already available today. Research is being conducted in the Nordic countries into energy and energy solutions and a website has been established

\footnotetext{
${ }^{65}$ http://www.nordicenergy.net/section.cfm?id=3-0\&path=142

${ }^{66}$ Reducing U.S. Greenhouse Gas Emissions: How Much at What Cost? conducted by McKinsey \& Company and published jointly with the Conference Board in November, 2007, available at: http://www.mckinsey.com/clientservice/ccsi/greenhousegas.asp
} 
to promote Nordic Energy Solutions on both a regional and international basis $^{67}$. Arguably the urgent issue is not so much in the creation of new component technologies but in the application of existing ones, in particular the integration of available component technologies in existing industrial systems. It would be of considerable interest to extend the work already performed by Nordic Energy Research, with a more explicit innovation focus.

Innovation is not only about research. Research is important and research policy has to position itself in the context of much larger innovation processes. The successful large scale adoption of Nordic climate solutions, not only in the Nordic area but in other world markets requires consideration of a range of issues such as:

- Strategies for adoption and integration into energy systems

- The role of the public sector as an early user of new technology

- The role of public procurement in creating new markets

- Business models based on economics, pricing, incentives and service

- Emerging economy business opportunities and engagement strategies

- Export readiness and adequate financing

It is important to understand how the creative burden and intrinsic risk of innovation remains a challenge for companies long after the basic technology has been demonstrated, from one market to the next. This is the key to understanding how the public sector can support innovation as distinct from the discovery of new science or technology on the basis of traditional $\mathrm{R}+\mathrm{D}$.

When one talks about solar energy and solar panels the focus of the discussion tends to be on the relative merits of different technologies. In reality, mainstream consumers have only a passing interest in this. They care more about issues such as:

- Can they afford it in terms of initial and recurring costs

- Does it require frequent maintenance, and if it breaks down what can they do and how much will it cost?

- Will it meet their needs or complicate their lives? Will it look nice?

- Can they replace it with something better one day?

\footnotetext{
${ }^{67}$ http://www.nordicenergysolutions.org/
} 
From this perspective, innovation is not just about the technology but also about the possibility of integrating it into the architecture of the house or building so that it looks good. This requires collaboration with designers and architects and not with scientists in national research laboratories. It is risky work, fraught with uncertainty. It requires time, and money and patience before success is assured. Support for innovation should include support for these activities as well. Perhaps one of the most important areas that is often ignored due to the focus on technology, is the basic business model. In many cases solar energy installations require a substantial initial outlay and adoption is limited to those who can afford it, with or without the benefit of incentives, grants or tax-relief. In principle the user is rewarded with lower ongoing energy costs, but in reality the benefit will tail off if the system fails or is badly maintained. Some companies have adopted business models that make their products much more purchase friendly. In an age of open innovation when technologies can sometimes be licensed from anywhere around the world, there will be many companies competing with similar technologies or solutions with comparable levels of performance. The business model will be a major factor in enabling one to succeed at the expense of the others.

Sun Edison of the US ${ }^{68}$ has developed a business model where it:

- Owns and finances the solar installation

- Operates the installation and monitors performance

- Charges the consumer on a monthly basis for the power consumed

- Carries out all repairs and maintenance

This business model means that there is essentially no barrier to entry for the consumer. The model is easy to understand. The provider has every incentive to make sure that the system works and is well maintained. The provider has a predictable long-term revenue stream for the future. This kind of a business model leaves the provider ideally placed to deal with revenues from feed-in of surplus energy supplied to the grid. In effect, rather than building a giant solar array in the desert, Sun Edison has distributed it across the roofs and buildings of thousands of houses and

\footnotetext{
${ }^{68}$ http://www.sunedison.com
} 
buildings and has thus changed the economics of the solar power industry both from a provider and a consumer point of view.

Let's look at another example. This will illustrate how the design of the consumer or user experience provides the key competitive advantage. One of the big issues with electrical vehicles is the cost and capacity of the battery, combined with the burden on the owner of regular charging. In many cases the battery is an integral part of the car and a user has to "plug in" the car for charging overnight. Alternative business models exist. For example, Shay Agassi of World a Better Place ${ }^{69}$ has developed a business model in which the battery is separate from the car and users simply replace depleted batteries with ones that have already been charged. This process only takes a minute. It totally changes the experience for the user. In principle the user should not even have to pay for the battery, but only for the charge, in effect reducing the cost of the car. As battery technologies improve the user is not required to invest in a battery upgrade, but simply buy a better charge. The provider is given more freedom in terms of when and how to charge the batteries and can thus contribute to better load balancing. Charging could be done during off-peak periods for traditional electricity grids or, for example, when supply is running at a peak due to high winds at wind-farms. One of the first testbeds for World a Better Place is Denmark, where the Danish government and DONG, the largest national power supplier, are working on how to implement the business concept of World a Better Place in Denmark.

Although the major players in the US car industry have received a lot of criticism in recent years and GM, historically one of the most successful innovators, has essentially been taken over by the US government, it is worth recalling that the growth of General Motors was largely due in no small part to its ability to innovate in management, marketing and sales. GM segmented the market in terms of user and ability to pay. It developed the idea of a product range that would cater to every user and every purse. It was the first in the US to use colour and styling as a differentiating factor and imported the best designers from Europe to help achieve this goal. Banks considered cars as dangerous toys for sports enthusiasts and refused to finance them so GM developed hire-purchase and insurance products for their customers. They developed dealer systems for distribution. They developed the market for second-hand cars

\footnotetext{
${ }^{69} \mathrm{http}: / /$ www.betterplace.com/
} 
and techniques such as trade-ins which in turn created a ladder of aspiration whereby young dives would buy-second hand. As their incomes increased they were able to afford more expensive models on the basis of trade-ins and tailored finance.

GM did not always get it right but many lessons can be learned from its glory days - that success is not just an issue of technology, but will respond to a creative and experimental approach to:

- Adoption strategies

- Pricing and payment, and consumer finance

- Consumer- and provider-side incentives

- Design in terms of engineering, performance, installation and maintenance

- Design of the product-service mix and the customer experience

- Maintenance, recovery and recycling

These two examples are intended to illustrate that innovation is just as much about the business model as about the technology. Once technologies are available, the battle for the consumer shifts very quickly beyond the mere possibility of renewable energy to options, finance and the consumer experience.

It is important for the public sector to understand that the incentives they put in place to encourage the adoption of new technologies are an important part of the business model of an industry in its early stage of development. Many technologies already exist and many more are in the pipeline. The job of the public sector is less to champion technologies and more to create favourable conditions for achieving high-level goals in the best way possible. To do this it is necessary to have a view of innovation that extends far beyond the development and dissemination of new technologies.

\section{The role of cities}

Cities contribute more than two-thirds of global greenhouse gas emissions, and according to the CCI or Clinton Climate Initiative ${ }^{70}$, they consume 5\%

\footnotetext{
${ }^{70}$ http://www.clintonfoundation.org/what-we-do/clinton-climate-initiative/
} 
of the world's energy and produce $80 \%$ of the world's GHG emissions. Cities therefore have a key role to play in the climate-change agenda.

The CCI addresses climate change on various fronts - one of which is energy efficiency in cities. The "Large Cities Climate Leadership Group" started in 2005, as a coalition of leaders from 18 of the world's largest cities committed to climate change, became partners with the CCI in 2006 and, having expanded to 40 members, changed its name to $\mathrm{C} 40^{71}$. Copenhagen and Stockholm are involved in this work which includes advocating measures such as LED street lighting, the retro-fitting of buildings to reduce energy use, waste management and the systematic measurement of emissions. Members of the C40 published action plans. Copenhagen for example aims at 20\% reduction of GHG emissions by $2010^{72}$ and Stockholm aims for a $60-80 \%$ reduction by 2050 . To put this in perspective, Toronto is aiming at an $80 \%$ reduction by $2050^{73}$ and Melbourne at zero-emissions by $2020^{74}$.

In 2008, London set-up a city-wide waste and recycling board that brings together stakeholders in the waste industry, with a focus on recovering energy from food waste and the recycling of plastics. It has created a brokerage service by which waste-producers such as food manufactures and retailers are linked with recyclers and energy users. The initiatives can ultimately be self-financing or even money-saving. The London board has stated that "the total energy that can be supplied by waste is $£ 504 \mathrm{~m}$ or 10 per cent of London’s gas and electricity bill”. It is easy to say "do the math", but the math is complicated and more effort needs to be made to demonstrate fully what is often a sound financial and business basis for initiatives that can be good not just for the city, but for emerging new business sectors and the planet as a whole.

Norway intends to be a zero-emissions country by 2020. Norwegian cities have an important role to play and can set an example to the world. Arguably all major cities and towns have a role and should put in place plans to achieve declared climate goals, not just through savings and efficiencies, but also by creating jobs and employment using climate change as a catalyst for innovation and creativity.

\footnotetext{
${ }^{71}$ http://www.c40cities.org/

${ }^{72}$ http://www.kk.dk/sitecore/content/Subsites/Klima/SubsiteFrontpage/ HvadGoerKoebenhavnsKommune/KoebenhavnsKommunesklimaplan.aspx

${ }^{73}$ http://www.toronto.ca/changeisintheair/

${ }^{74} \mathrm{http} / / /$ www.futuremelbourne.com.au/wiki/view/FMPlan/S2G3P1ZeroCarbonCity
} 
There seems to be an emerging link between climate change initiatives and creativity that will be of considerable interest to agencies intending to promote inward investment. Fast Company is a U.S. publication on design, innovation and creativity in the broadest sense, and has recently identified the 13 most creative cities in the world ${ }^{75}$. The only European city currently featuring in the list is Malmø in Sweden. It is ranked at No. $8^{76}$ and its position is based on its policies for creating eco-friendly neighbourhoods by transforming tenements and old shipyards. Fast Company notes that "much of Western Harbour now runs solely on renewable energy, including wind and solar, while organic waste from the area is turned into biogas. In Augustenborg, roof gardens reduce runoff and insulate homes, while a carpool system, pedestrian- and bike-friendly roads help cut vehicle use. The city expects to reduce its $\mathrm{CO} 2$ emissions by 25\% between 2008 and 2012, blowing past the Kyoto Protocol's 5\% target." It is clear that public administration has the potential to generate a considerable impact on climate-security. The city of Malmo is a good example of how this can happen. It is worth noting that the champions of innovation in this context are not just the captains of industry but, also the visionary leaders in public administration. They have their own specific learning and research, combined with a need to experiment with innovative climate measures that have a much more explicit systemic dimension than those that affect many players in the private sector.

It is interesting to note that Taipei ${ }^{77}$ is ranked No. 6, 2 places ahead of Malmo. The city encourages the private sector to build composting facilities and recycling plants. It promotes trade in secondhand goods and has introduced new methods of kitchen-waste disposal. For example, there is a pilot project that involves converting food waste into pig feed. The result is that it has already reduced the volume of city waste by over $60 \%$. Fast Company reports that it wants to achieve "zero landfill" and "total recycling” by 2010. This very goal is in advance of the UN trash target by 30 years. It is clear that these goals will not be reached without innovative approaches to the management and organization of the city's affairs.

The examples of Malmo and Taipei raise issues of interest for industrial clusters. It is clear that cities with policies such as these, as well as

\footnotetext{
${ }^{75}$ http://www.fastcompany.com/cities/2009

${ }^{76} \mathrm{http} / / /$ www.fastcompany.com/magazine/135/fast-cities-malmo-sweden.html

${ }^{77}$ http://www.fastcompany.com/magazine/135/fast-cities-taipei-taiwan.html
} 
being attractive places to live are attractive places for climate related businesses to operate.

This is not just an issue for city administrators, but also the companies that supply cities with services. The market for such companies comprises not only the visionary Nordic cities, but also the visionary cities of the world, and programs to support innovation might one day help such companies to expand beyond their home base, and to address the markets for city-oriented services throughout the world.

The networking of public administration in this way makes a lot of sense. Innovation is not the preserve of private industry. The public sector is under great pressure to innovate. The cost of provision of infrastructure, education, health care and other services increases much more quickly. Innovation in organization and management, combined with services, needs to become a core capability of a modern well-run city. The public sector needs to continuously reinvent and improve the business model of modern society - the business model that links the services provided by the state with the taxes and other revenues that pay for them. They create the demand for climate technologies, and have a very important role as users in user-led innovation initiatives. They need to consciously develop a capability for innovation and can help each other by establishing:

- Common Measurement Tools: Cities need to measure overall energy consumption and emissions. These data will act as a support for climate related decision-making, benchmarking among peers and the branding of the city as a modern, progressive venue for living and working.

- Expert Assistance: Exchanging and demonstrating good practice in the development and implementation of programmes to reduce energy use and lower greenhouse gas emissions by focusing on building efficiency, cleaner transport, renewable energy production and waste management, combined with water and sanitation systems.

- Public Procurement: They can work with vendors to lower production and delivery costs, while encouraging climate friendly building materials, traffic and street lighting, buses and waste disposal trucks, combined with waste-to-energy systems.

It is worth considering a greater and more explicit role for public administration in the innovation game. This should give consideration to capac- 
ity and know-how building related to the public sector's role in terms of climate and energy related innovation, such as in the fileds of energy management and public procurement. The key questions include how to exploit procurement to:

- Achieve targets for 2020 and 2050.

- Support innovators and entrepreneurs with new, high-risk ideas.

- Enable the early stage growth of small and medium-sized enterprises.

Measures to support the peer group learning among public sector professionals could be of particlar value:

- Appoint 2020 or 2050 officers at region or city level, responsible for meeting the corresponding climate targets. Their job could be to maintain a vision for the region in terms of the acheievement of targets and ensure that data are acquired to track and report on progress. They could maintain a portfolio of relevant projects and work, together with providers of technology and know-how who want to be involved.

- Benchmark regions and cities

- Reward top performers such as the top 20 most sustainable cities, towns and villages.

One of the issues policy makers like to address when considering research and innovation is the role of risk. The state assumes risks that the private sector would normally eschew. It could be interesting to examine the concept of risk and the rationale behind public intervention in light of the public commitment that public administration sometimes makes in the pursuit of climate and related sustainability goals. Risk is not just technical or scientific, but socio-political and financial. The basis for the public funding of climate related innovation may need to be expanded to include the risk of not meeting targets necessary to avoid the worst effects of climate change. This would have the effect of:

- Demonstrating the possibility of reaching targets

- Maintaining local momentum to achieve results with high impact

- Maintaining international momentum and solidarity for a project that requires a concerted global effort from all nations. 


\section{Land-use, food, agriculture and forestry}

Forestry is an important sector for several Nordic economies, and in particular for Finland and Norway. It plays an important role in the dynamics of climate change. Although forests by themselves are an important carbon sink and mitigate climate change, deforestation alone is responsible for up to $20 \%$ of global carbon emissions. According to the World Watch Institute, agriculture and land-use accounts for $30 \%$ of current man-made emissions, and its impact is comparable to that of the transport and industry sectors combined.

A recent report by the $\mathrm{UNEP}^{78}$ highlights the potential of the world's forests and farmland to help absorb man-made atmospheric carbon. The report proposes that reducing the rate of deforestation by $50 \%$ by 2050 and maintaining it at this level until 2100 would provide benefits equivalent to a reduction of emissions by $12 \%$. The report also claims that the agricultural sector could become virtually carbon neutral by 2030 if sustainable management practices were followed. Reducing the rate of deforestation and adopting better land use practices could lower global emissions by up to $30 \%$.

Norway has therefore established an international climate and forestry initiative $^{79}$ with the aim of reducing global GHG emissions. This is closely linked to the UN-REDD programme for Reducing Emissions from Deforestation and Forest Degradation in Developing Countries ${ }^{80}$ and part of a series of international initiatives such as the World Bank's Forest Carbon Partnership Facility ${ }^{81}$, the Global Environment Facility Tropical Forest Account $^{82}$, and Australia's International Forest Carbon Initiative ${ }^{83}$.

The World Watch Institute has recently sought to highlight the role of food and farming in the dynamics of climate change ${ }^{84}$, in particular the role of the soil in carbon sequestration. The author points out that science and policy communities in Europe and elsewhere have focused most of their attention to date on improving energy efficiency and scaling up

\footnotetext{
${ }^{78} \mathrm{http}: / /$ www. unep. org/ pdf/ BiosegRRA scr. pdf

${ }^{79} \mathrm{http}: / / \mathrm{www} \cdot$ regjeringen.no/templates/Tema.aspx?id=548491\&epslanguage=EN-GB

${ }^{80} \mathrm{http}: / /$ www.un-redd.org/

${ }^{81} \mathrm{http}: / /$ go.worldbank.org/9IGUMTMED0

${ }^{82} \mathrm{http}: / /$ www.gefweb.org/default.aspx

${ }^{83} \mathrm{http} / / / \mathrm{www} . c l i m a t e c h a n g e . g o v . a u / i n d e x . h t m l$

${ }^{84}$ EWP179 "Mitigating Climate Change Through Food and Land Use", www.worldwatch.org
} 
renewables, but that "any strategy that seeks to mitigate global climate change without reducing emissions from agriculture, forestry and other land uses is doomed to fail". The report claims that innovations in food production and land use that are ready to be scaled-up today could reduce $\mathrm{CO}^{2}$ emissions by the equivalent of some $25 \%$ of global fossil fuel emissions. They outline a five-fold plan to achieve this. It calls for the incorporation of terrestrial emissions into climate investment and policy, and the promotion of voluntary markets for greenhouse gas emission offsets from agriculture and land use "while working out rules for regulated markets”.

In Australia 27\% of human-induced greenhouse gas emissions are generated by activities such as livestock, crop-production and land clearing. It has set up a national carbon accounting system ${ }^{85}$ to account for carbon emissions related to land-based sectors such as agriculture and forestry. It publishes national greenhouse accounts ${ }^{86}$ with a break-down according to region and industrial sector. The Nordic countries have not come this far, but it would make sense for them to examine the feasibility and benefits of doing so.

Food, farming and land-use in general are of importance for all economies. It would therefore be useful to investigate the overall role of these sectors in the Nordic region.

- What is the role of land-use change for climate change mitigation and adaptation in the Nordic countries?

- How could the Nordic region achieve carbon neutral agriculture by 2030 ?

- Can it do this while meeting the growing need for food, feed and fiber?

- How will this affect global supply chains, food security, and the distribution of related industrial activities and patterns of trade?

- What role will technologies play in providing workable options?

- What are the implications for future land-use policies?

- What is the impact on agri-business activity?

- What measures need to be taken to support innovation?

- How should this shape the future research agendas related to land-use, environment, tourism, agriculture and forestry?

\footnotetext{
${ }^{85}$ http://www.climatechange.gov.au/ncas/index.html

${ }^{86} \mathrm{http}: / /$ www.climatechange.gov.au/inventory/index.html
} 


\section{Water, fisheries and the marine environment}

Climate change has caused an observable increase in the frequency and intensity of extreme weather events. It has caused changes in the patterns of precipitation of rain and snow that have increased flooding and changed the large-scale hydrology of certain regions. It will have a big impact on the Arctic region in terms of the retreat of glaciers, permafrost and sea ice. There is even a fear that the associated release of GHG from peat-bogs and tundra could increase warming by even greater levels than previously anticipated.

The UNEP report on "Climate Change and Water" ${ }^{87}$ explains these changes and how they come about in some detail. Temperature changes will affect agricultural yields and bio-diversity as well as the spread of disease and parasites related to intensive agricultural and fish production. We expect an increase in species extinction. We also expect a natural reduction in forestation, and sea level rise will affect marine eco-systems, with consequences for fisheries and associated patterns of human habitation and industrial activity. Coastal wetlands and estuaries are among the most biologically productive in the world. Climate change will have an increasing impact on aquaculture, the migration of invasive species, and will heighten the risk to stocks from disease and harmful algal blooms. The impact on marine eco-systems is due to:

- Acidification arising from increased levels of $\mathrm{CO}^{2}$ in the atmosphere

- Surface water and coastal area temperature changes due to warming

- Weather patterns including increases in storm frequency, rain, run-off and sea ice occurrence

The sea has an important role in carbon sequestration. The main contributors are kelp and phytoplankton, which essentially represent the forests and savannah grasses of the sea. $\mathrm{CO}^{2}$ dissolves more readily in cold water than in warm water so the effects of acidification could be expected to be greater in the more northerly waters of the Nordic region. Although we can easily monitor terrestrial forests by satellite, the seas are much less accessible. They may play a bigger role in the future in terms of carbon sequestration on the basis of geo-engineering or on the basis of kelp forests associated

\footnotetext{
${ }^{87}$ http://www.ipcc.ch/ipccreports/tp-climate-change-water.htm
} 
with modern sustainable fish farms. They may play new roles in industry, in the production of bio-fuels, cosmetics, food and medicine.

Given their extensive coastline, the importance of fishing and sea-food as an industry, combined with their privileged relationship with the Polar Regions, there is arguably a need for the Nordic countries to increase their investment in:

- Basic science to promote understanding of the impact of climate change on marine and industrial eco-systems as well as on key global resources such as the arctic region.

- Innovation, technologies and strategies to help industries from fishing to tourism which may be poorly suited to adaption.

- Support for innovation based on the sustainable exploitation of marine resources, not just in terms of food, but also in relation to non-food or food-related sectors such as bio-fuels.

\section{Other sectors}

Climate change affects many sectors in addition to energy, agriculture, forestry and fishing. All sectors are to some extent energy intensive and thus all have to develop a response in terms of energy efficiency. Many sectors will have to adapt to changes that are imminent and unavoidable. Many sectors see the greening of the economy as a branding opportunity that will allow them to establish a superior position in terms of product placement. We will briefly look at the implications of climate change for sectors such as manufacturing, retail, logistics and IT.

In April 2009 Aberdeen released a series of reports on green product development ${ }^{88}$. Based on surveys which the city had carried out in 2008 they found that:

- $50 \%$ of consumer packaged goods providers regarded the ability to achieve product differentiation via green product development was the single greatest challenge they faced.

${ }^{88}$ www.aberdeen.com 
- $54 \%$ of industrial machinery manufacturers found that their main challenge was to provide increasingly energy efficient systems

- $78 \%$ of automotive manufacturers had some kind of a green initiative in place.

- $81 \%$ of high-tech and electronics manufacturers had a green product development program in place

Transport is responsible for $71 \%$ of oil consumption and for $26 \%$ of $\mathrm{CO}^{2}$ emissions. Logistics account for an estimated $10-15 \%$ of the final cost of finished products. Businesses are therefore increasingly seeking to cut costs by reducing fuel consumption and time spent in queues. In addition to reducing costs, industries are now concerned with their carbon footprint as part of a significant trend that considers greenness as an important differentiating factor in the provision of goods and services. The public sector has an important role to play in terms of traffic management, the planning of logistics hubs and freight corridors. Cities have taken numerous initiatives to "green" transport and supply chains ${ }^{89}$. Green-powered vehicles also have a role to play.

Postal operators and express services, for example, often represent the largest vehicle fleets in any given country and are particularly reliant on fast, low-cost solutions. Whereas battery power and hybrid systems already work well for personal transport and certain kinds of vehicle fleets, bio-fuels will also play an important role. A range of programmes are currently addressing logistics at European level. For example, since 2003, the EU financed Marco Polo program ${ }^{90}$ has been established to promote innovative transport solutions. Estimates from before the financial crisis suggest a 50\% growth in volume of world trade between 2005 and 2020. This figure may have to be revised but there is no doubt that supply chains have become longer and more complex. There is a need for international co-operation on logistics issues.

Iceland has been highly innovative in offering itself as a venue for the smelting of aluminium and for the processing for food of fish caught in northern waters. Smelting is very energy intensive but Iceland can

\footnotetext{
89 "A review of green logistics schemes used in cities around the world" by Nikolas Geroliminis and Carlos F. Daganzo of Department of Civil and Environmental Engineering, Institute of Transportation Studies, University of California, 416 McLaughlin Hall, Berkeley, CA 94720, USA ...http://www.metrans.org/nuf/documents/geroliminis.pdf

${ }^{90} \mathrm{http} / / /$ ec.europa.eu/transport/marcopolo/home/home_en.htm
} 
achieve this in a carbon neutral way using electricity generated from geothermal sources. An argument is emerging that this not only brings jobs to the region but also makes a significant contribution in the fight against climate change. Smelting has grown rapidly in China in recent years where it is fuelled by energy from coal. Were it not for Iceland, China would probably be producing much more aluminium, but with a negative impact on the environment. The Economist recently asked "if "if electricity is going to be made anywhere, it might as well be made where it does the least damage to the environment”. Having said that smelting has become a controversial issue, and environmentalists have objected to the fact that bauxite is often transported over long distances prior to processing. Finding ways to reduce the carbon footprint of the marine transport of bauxite to Iceland would help to address these concerns.

This example illustrates a broader strategy of greening entire supply chains by harnessing the natural advantages of the Nordic region. The region offers a range of zero-carbon energy alternatives for energy intensive industries, as well as the opportunity to exploit natural sources of heat and cold for greenhouse agriculture or the operation of server-farms for data-intensive industries. The focus of Nordic innovation on lowcarbon energy intensive industries should encompass issues such as the greening of the whole supply chain and not just the energy required for processing. It should look at the challenge of greening transport and distribution networks, together with reducing the impact of activities on the local environment on the basis of architecture and design. The argument made by the Economist that countries such as Iceland should "use its plentiful clean energy for the benefit of the planet" is one that extends to the whole of the Nordic region. The greening of the global supply chain in terms of the intensive use of energy is one that would help the region build upon its existing natural and technological advantages, by explicitly addressing issues that we have in common with the greening of the supply chain as a whole.

McKinsey, the global consultancy firm, has written extensively on how IT can cut emissions ${ }^{92}$ by measuring the impact on greenhouse gas emissions of the manufacture, distribution and use of IT. It estimates that

\footnotetext{
${ }^{91}$ Based on an article entitled "Testing metal" from the 29th Sep 2008 edition of the Economist.

${ }^{92}$ McKinesy "How IT can cut emissions”, http://www.mckinseyquarterly.com/ PDFDownload.aspx?ar=2221
} 
despite the fact that ICT will continue as a major source of greenhouse gas emissions, the changes it will bring about can promote emissions reductions of as much as $15 \%$ of current levels. Major IT industry related companies in the Nordic region, such as Ericsson and Nokia have made considerable commitments to reducing the emissions relating to their equipment.

Retail is almost totally ignored in the innovation literature, but it has its own very specific forms of innovation, and can be a powerful force in transforming the capabilities of small and medium sized companies in the value chains where it is an active participant. It currently functions as an important lever in the greening of supply chains.

High profile examples in Europe include Siemens and Philips. Philips launched its EcoVision program in 2005 to improve the energy efficiency of its products and operations. In 2007 20\% of EcoVision sales were of products that typically demonstrated a $20 \%$ energy saving over their predecessors. In 2008 this figure increased to 23\%. That year it released almost $80 \%$ more new green products that the year before. Siemens has made a significant commitment to green product development and, according to a recent Reuters Report ${ }^{93}$ it expects to increase revenues from its green product portfolio from $€ 19 \mathrm{~B}$ in 2008 to $€ 25 \mathrm{~B}$ in 2011 despite the worldwide slump that has already affected its order flow.

Wal-Mart is now the world's largest company. In 2008 it sold \$245B worth of goods. It has become famous - or perhaps notorious - for its policy of squeezing suppliers to get the best price for its customers. Most recently it has started to adopt a sustainability agenda that will involve a social and environmental assessment of all of its suppliers. It has announced that those who do not or will not measure up to its criteria for sustainability will not be retained. Its 2009 sustainability report ${ }^{94}$ announced targets of $100 \%$ renewable energy and zero waste. Although it is one of the largest solar panel installers in the US it has to date only achieved levels of $1 \%$ renewable energy consumption. On the other hand it has already achieved a 57\% reduction in own-waste sent to landfill. It has undertaken initiatives in the area of organic clothing and food, sustainable sea-food, fuel efficient vehicles and building efficiency. It has established energy efficiency and performance inititives with its suppli-

\footnotetext{
${ }^{93} \mathrm{http}: / /$ www.reuters.com/article/GCA-BusinessofGreen/idUSTRE52N2AX20090324

${ }^{94} \mathrm{http}: / /$ walmartstores.com/Sustainability/7951.aspx
} 
ers, as well as improvements in packaging and the use of renewable material inputs. To achieve these goals it has established a series of "sustainable value networks" 95 involving dedicated structures and human resources addressing themes such as alternative fuels, logistics, waste, packaging, food agriculture and fisheries.

The need to address climate change has created a new service industry based on the trading of carbon credits. All 27 EU countries are part of this system, together with Iceland and Norway. Many other countries are preparing to join in as well to what could eventually become a global carbon market. However, this kind of trading is not necessarily limited to carbon. It can be used to commoditise other environmental (and therefore social) goods. Lots of examples are provided on the website of the EcoSystem marketplace ${ }^{96}$.

Many new sectors are currently emerging either as a direct or indirect result of the urgency of climate change mitigation. These are linked to better resource exploitation, recycling, the processing of organic waste or urban sewage, the generation of clean water, bio-gas and compost, technologies for the retro-fitting of buildings and renewable construction materials. They include broader knowledge-based bio-economy sectors related to the greening of retail, bio-polymers, the reduction of pollution and the application of the most advanced areas of S+T such as syntheticbiology for food, medicine, energy and the production of bio-polymers and other industrial feedstock.

Finland has 1,200 cleantech companies, of which about 200 belong to the 4-centre cleantech cluster called "Cleantech Finland" ". The sector is growing globally at between $5-15 \%$ a year. The cluster was set up to help Finnish companies establish contacts with international markets. The NETS project ${ }^{98}$ financed by the Nordic Innovation Centre in Oslo provides a platform to support the commercialisation of clean-technologies developed in the Nordic region.

These lists are not exhaustive. They are intended to illustrate how climate change has created complex ripples throughout local and international supply chains. The conclusion is that traditional approaches to understanding innovation may not be adequate to bring about the changes

\footnotetext{
${ }^{95} \mathrm{http} / / /$ walmartstores.com/sites/sustainabilityreport/2009/en_threeKeyGoals.html

${ }^{96}$ www.EcosystemMarketplace.com

${ }^{97}$ www.cleantechcluster.fi/en

${ }^{98}$ www.nordiccleantech.net
} 
required on a scale necessary to achieve the challenge of keeping global warming below the $2^{\circ} \mathrm{C}$ threshold prior to 2100 . More integrated value chain approaches may be required.

\section{The specific challenge of climate-related innovation}

Innovation is a challenge for all companies in today's more or less global open-market economy. The meaning of innovation for a company usually boils down to winning clients or customers in a competitive market-place. The time scale for achieving this is usually of the order of months or years. However, the climate innovation challenge is not the property of any company, but belongs to society as a whole. The Stern review and subsequent reports conclude that if we do not keep global warming below an average of $2^{\circ} \mathrm{C}$ the consequences for national economies, marine and terrestrial eco-systems and patterns of human habitation will be quite drastic. Improved data and model revisions over the last years tend to indicate that the impact of current emission levels on climate change and all of its consequences could be even greater than previously thought. The risks involved are of a different order than those involved in terms of the levels of innovation required in the normal course of events. Success requires cooperation by all major participants and their supply chain partners, not just in the Nordic countries or in Europe but eventually all around the world. For this reason it may be necessary to "force" innovation by setting binding targets for the reduction of greenhouse gas emissions. These targets are then broken down on a sectoral basis with the current focus being on energy.

The various approaches by which the public sector steps in to actively encourage innovation in key areas through legislation and by using the leverage of its enormous spending power, can be thought of as "forced" innovation. This is a situation where real pressure to innovate is applied to all companies in the category in question, in response to a situation where innovation is no longer an option but a necessity. It is likely that there will be more of this in the future.

Compliance is not usually associated with innovation, but compliance forces innovation. One example of a public intervention carried out to force innovation provides an interesting model for other countries and 
regions to consider. The Japanese "Top Runner" programme for energy efficiency is applied in connection with machinery and appliances ${ }^{99}$. On a category by category basis the programme identifies the most energyefficient models already available on the market. These are referred to as the "top runner" models in that category. The government then stipulates that the current efficiency of the top runner model should become the standard within a stated period of time, such as five years. This approach constantly ratchets up the performance of industry with each new generation of targets. The advantage of this approach is that innovation laggards within a given category know that the goals are achievable because they are based on existing best-in-the-class models. They also know that they have a specified period of time such as five years in which to catch up or face exclusion from the game. On the other hand innovation leaders also know that the market will have caught up with them in five years time and this gives them the incentive to continue to innovate and exceed what will become the norm in five years time. Compare this with the usual approach by which minimum standards are set and where industry has little incentive to do more than simply comply because exceeding the standard will not earn them any extra recognition.

Another important approach was championed in 2006 by Esko Aho, former Prime Minister of Finland. The "Aho Report" entitled "Creating an Innovative Europe" became an important European contribution under Finland's Presidency of the European Union ${ }^{100}$. It focused on the creation of innovation friendly markets and emphasizes the potential role of governments in the creation of lead markets for important areas of innovation. What this amounts to in practice is that governments will be using their systems of public procurement to encourage innovative products and services. The European commission has taken this on board and has adopted this approach as an important element in achieving the Lisbon agenda. Lead Market initiatives ${ }^{101}$ have now been established in sectors such as e-health, construction, recycling, renewable energy and renewable raw-materials. GPP or Green Public Procurement is the application of environmental non-price criteria by the public sector to purchasing deci-

\footnotetext{
${ }^{99}$ Go to http://www.eccj.or.jp/index_e.html to find out more about the programme and download the report at http://www.aid-ee.org/documents/018TopRunner-Japan.PDF for an evaluation.

${ }^{100} \mathrm{http}: / /$ ec.europa.eu/invest-in-research/action/2006_ahogroup_en.htm

${ }^{101}$ http://ec.europa.eu/enterprise/leadmarket/leadmarket.htm
} 
sions. It enables the public sector to pay more than the lowest prevailing price for a product or service, in order to capture an environmental or social benefit. The most straightforward examples involve the purchase of bio-fuel fleets. However, public procurement can achieve even more by supporting the innovation process in more direct ways. For example, it might be used to purchase hydrogen-buses or new types of electric vehicles which may not yet have reached mainstream markets. Such early purchase of an advanced technology allows the company to earn early revenues from their investment in research and development. It improves their financial standing and their ability to continue investing in the innovation process. It demonstrates the feasibility of the technology or solution in question and provides user feedback and market-learning experiences that are essential for a successful launch. Public authority spending in the EU amounts to about $16 \%$ of EU GDP or about $€ 2,000 \mathrm{~B}$ each year. The greening of public procurement rules at EU and national level is seen as a means of substantially reducing unsustainable production and consumption patterns, and could serve to introduce new environmental technologies to the market.

Only 7 EU countries have made a substantial commitment to GPP. These include Denmark, Sweden and Finland. The EC has proposed that all governments in Europe should aim at 50\% GPP based on common criteria by 2010. Ten priority sectors have already been identified for the introduction of GPP on the basis of their potential impact on climate change, among other things. These are construction, food and catering services, transport and transport services such as “clean vehicles”, energy, office machinery and computers, clothing, uniforms and other textiles, paper and printing services, furniture, cleaning products and services, and health sector equipment. GPP has a role to play not only in helping innovators and creating lead markets, but also in demonstrating that green need not be expensive. It helps to mainstream quality initiatives such as eco-labelling or energy-labelling.

The Nordic region has already established a lead in the area of GPP. Perhaps it should maintain and extend this lead in order to achieve global pre-eminence in the use of procurement to support innovation. It can achieve this by becoming more involved in user-driven innovation, by acting as a first client for new products, and by helping to build lead mar- 
kets in areas of importance to the environment and society as a whole. It is worthwhile considering measures whereby:

- All governments open up their procurement markets

- All administrations develop procurement strategies that favour climate friendly solutions

- They set aside funding for smaller companies

- They set aside budget funds for the purchase of innovative high-risk solutions so as to participate in their demonstration and assessment

- They benchmark progress towards $100 \%$ green procurement

- They, as in Finland, develop innovative municipalities whose missions are to act as "living laboratories" for climate mitigation strategies and green procurement practices

- They create a new research discipline related to the use of public purchasing power to accelerate all stages of the innovation cycle, from research to demonstration and full scale market deployment

To date two approaches have been mentioned regarding "forced innovation". The need to force derives from the urgency of the climate change issue and the acceptance of legally binding targets for emissions and renewable energy production. The two methods involve firstly, the use of programs such as the Top Runner program in Japan, and secondly, the use of green public procurement. Both have been discussed to some extent in the literature on innovation. A third approach attracts less attention and this might be a good opportunity to examine in further. This is the "Wal-Mart" approach whereby supply chain leaders put pressure on those further down the hierarchy to share the burden of becoming green.

One issue of interest to innovation researchers in the future could be the extent to which major retailers and branded goods producers work with their supply chain partners, the nature of this cooperation and the possible need for measures to support small and medium sized enterprises to manage the transformation required.

It is important for the Nordic region to address climate issues in the market as quickly as possible. The risk is that by waiting they will lose their competitive edge to the suppliers of Wal-Mart as low-cost economies become high-value suppliers of climate friendly goods. 
In a recent book ${ }^{102}$, Amar Bhidé stresses that the application and commercialisation of science and technology is a far more important part of innovation than the underlying process of scientific discovery. This observation is borne out by marketing experts who know that most new products or services introduced to the market fail. On the basis of 25 years' experience in bringing new technology products to the market, the Eco-Stategy Group recently claimed that the main reasons for product failures in the market-place are: ${ }^{103}$

- Poorly defined or incorrectly defined target markets

- Badly positioned product

- That product benefits not understood by the target customer.

- That the product fails to address important customer needs.

- That the product costs too much or the total cost of ownership is out of line with perceived benefits

Amar Bhidé also points out that the greatest benefits of innovation accrue to the users of an innovation and not to the original inventors. His arguments suggest that in exploring the systemic dimension of innovation to achieve a sustainable, climate friendly mode of economic progress, it is worthwhile paying attention not only to value chain issues, but also to the benefits that accrue to consumers in terms of energy savings, carbon credits, resource efficiency, compliance, branding and efficiency. When addressing climate change, it is worthwhile paying attention not only to scientific and technological innovation, but also to the creation of innovation related market intelligence and to innovation in marketing and sales which is essential if the promise of new jobs and business opportunities is to be kept.

In most periods in economic history it is not always entirely clear from where the next "new idea" will come from or how important it is likely to be. Nordic, European and even global policy trends indicate that factors such as carbon markets, climate change, renewable energy and industrial feedstock, recycling and the efficient use of energy, water and other natural resources, will assume increasing importance in the years to

102 "The Venturesome Economy - How innovation sustains prosperity in a more connected world” published in 2008 by Princeton University Press, ISBN-13 978-0-691-13517-5.

${ }^{103}$ www.sustainablelifemedia.com/content/story/strategy/

top_ten_reasons_why_new_green_products_fail 
come. These sectors are essential components of an emerging sustainable economy. The global transition will affect not only existing companies and start-ups, but also the entire value chains to which they belong. This requires innovation at system level and on an unprecedented scale. Policies may need to pay more attention to issues such as the sourcing and adoption of new technologies if change is to be achieved on a scale sufficient to meet national and international energy and climate security goals.

The impacts and cross impacts of climate change on society and on the environment have been closely examined. However, relatively little work has been done on the impact of climate change and its policies on the industrial and trade systems at national, regional or world level. What has been done has mainly been qualitative in nature, but it has served to indicate the complexity that must be addressed, and provides a starting point for further analysis. The economic impact of climate change has been limited mainly to the costs of damages, mitigation or adaptation, and the costs associated with disasters, sea-level rise or the increased burden of health care. Relatively little has been done on the upside on the part of industry in terms of new business oppportunities, either regionally or globally. Studies of this kind that not only deal with the market place for energy or global carbon trading, but which also examine the ripple effects within supply and value chains, can play an important role in understanding the specifics of the innovation challenge faced by small and medium sized companies competing in nascent markets and with global opportunities.

Innovation researchers in the US have already started to look at the systemic impact of low-carbon technologies on the economy, by investigating how these changes will affect the entire production value chain. In a report entitled "Job Opportunities for the Green Economy - a state by state picture of occupations that benefit from the green economy" ${ }^{104}$, US based PERI - the Political Economy Research Institute of the University of Amherst, worked with Duke University's Center on Globalization, Governance \& Competitiveness to map out the value chains of the following five low carbon technologies and products:

- High-efficiency energy LED lighting

- High performance energy efficient windows

- Anti-idling technology for heavy duty trucks

${ }^{104}$ http://www.peri.umass.edu/fileadmin/pdf/other_publication_types/Green_Jobs_PERI.pdf 
- Concentrated solar power

- Systems for recycling pig waste

This is not intended as an exhaustive list, and work is ongoing on other applications. However, they are examining how these different climate solutions are manufactured and how the benefits of this activity are distributed throughout the value chain. One example that will be especially meaningful for the Nordic countries is that of wind turbines. According to their report, a wind turbine contains 8,000 components manufactured by tens if not hundreds of suppliers. As demand increases among the turbine manufacturers, so does business for the producers of each one of these components. The report follows the links in the value chain of US based wind turbine manufacturers to determine the overall potential for growth that they represent. In particular they show that growth in these obvious environmental technologies has considerable benefits for sectors not normally associated with environmental conservation.

The methodology used is based on the provision of:

- A working understanding of each technology, broken down into its primary materials and components

- A view of the value chain that includes materials, component manufacturers, assemblers, and the distributors linked to each technology

- A view of the types of labour involved in manufacturing and installation

- A list of firms and a depiction of the market structure in which they operate

Other studies focus on the traditional skill sets that will be needed to make this happen. The transition is not concerned only with high-level scientific and technical jobs, but also with highly-skilled vocational jobs in areas such as the construction trades, pipe-fitting, metal-working and electrical jobs. All of these other sectors are part of the systemic change that the Nordic countries want to bring about.

Arguably, the Nordic countries lag behind in their understanding of how the transition to a low-carbon economy will benefit the economy. As a consequence, there is also a lag in terms of knowing how best to accel- 
erate the change and optimize the distribution of benefits. Future innovation policies could benefit from a more systemic approach addressing not only the high-end knowledge needs associated with climate-related $\mathrm{R}+\mathrm{D}$, but also issues such as the benefits accruing to end-users, complementary skills and supply chain dynamics.

Eventually it will be possible to propose a coherent set of interventions that go beyond $\mathrm{R}+\mathrm{D}$ to address innovation needs. This may require:

- Roadmaps for proof of concept, demonstration, large-scale demonstration and commercialisation, together with impact on jobs and economic growth

- Global market mapping of needs, magnitude, growth prospects, regulations, incentives, goals and targets, together with the extent of market fragmentation and conditions for penetration

- The opportunities presented in the form of emerging as well as developed economies

- The financing needs at different stages of new market development technology adaptation, demonstration and deployment

- The global market readiness of Nordic companies, the appropriateness of their capabilities, and the cost of adaptation to new skill-needs and new markets

- The need for business services, e.g., on the basis of a network of international innovation centres

Some work has already been done on more business and innovation oriented issues. For example, CICERO has published reports on the business implications of the Kyoto Protocol ${ }^{105}$, in addition to pro-poor Climate Adaptation ${ }^{106}$. The Nordic Innovation Centre has supported projects dealing with how to build Nordic strongholds within environmental technologies ${ }^{107}$ such as the use of wood as the basis of a bio-polymer industry. The NETS project ${ }^{108}$ in particular will support the commercialization of Nordic environmental technology businesses in five key sectors. These

\footnotetext{
${ }^{105}$ Report 2001:05 by Torvanger and Asbjørn. http://www.cicero.uio.no/media/1690.pdf

${ }^{106}$ Report 2003:02, "Pro-Poor Climate Adaptation: Norwegian development cooperation and climate change adaptation - an assessment of issues, strategies and potential entry points" by Eriksen, Siri and Lars Otto Næss http://www.cicero.uio.no/media/2465.pdf

${ }^{107} \mathrm{http} / / / \mathrm{www}$. nordicinnovation.net/article.cfm?id=1-834-804

${ }^{108}$ Nordic Environmental Technology Solutions
} 
include bio-polymers derived from wood, clean-water technologies, and green nanotechnology as applied in the construction industry.

The Nordic Environmental Action Plan for 2009-2012 could be further developed by explaining how it will be used to create jobs, markets, and opportunities for entrepreneurial new companies. Arguably, the system would benefit from complementary work using:

- A value chain approach

- The potential for local job creation both directly and throughout the value chain

- The potential for exports to emerging markets

There is a need to create new technologies to address climate change issues, but many already exist and no time should be wasted in releasing these to the market and onto a trajectory of innovation by means of continuous improvement. Climate change is as full of opportunity as it is of urgency, but we are not yet as skilled in measuring and understanding the opportunities presented as we are at understanding the danger. We can help to address this by considering a supply or value chain approach to innovation in all related sectors.

Much of the discussion of global change is conducted in very broad general terms on the basis of global models and simulations. Local governments and administrations must now learn to understand climate change from a very local point of view, not so much in terms of its effect on the planet but in terms of its impact on local environmental and industrial systems. Much work remains to be done to adapt existing tools for use by policy makers and non-climate scientists so that they can explore answers to the questions that they need to ask rather than those that drive scientific inquiry. This is no small task and it should not be forgotten in the discussion of climate-related public sector innovation needs. 


\section{References}

Andesen, Jørn Bang: “Global Innovation Hot Spots - A Taxonomy”, 2009, Nordic Innovation Center, Nordic Council of Ministers

Chesbrough, Henry, “Open Innovation: The New Imperative for Creating and Profiting from Technology” published in 2003 by Harvard Business School Press, and "Open Business Models: How to Thrive in the New Innovation Landscape" published in 2006 by Harvard Business School Press, NordTrend: NICe project, To be published 2009.

Kao, John” Big Picture - Tapping the World's Innovation Hot Spots” HBR, March 2009, pp. 109-114

Lafley, P. J: The Game Changer - How Every Leader can Drive Everyday Innovation”, published by Profile Books Ltd in 2008

US Government, A Report to the US Secreaty of Commerce by: The Advisory Committee on Measuring Innovation in the 21 Centry Economy, US State. Dep. Commerce, January 2008.

Amar Bhide: Page 112 of "The Venturesome Economy - How innovation sustains prosperity in a more connected world” by Amar Bhidé published in 2008 by Princeton University Press

Hamel, Gary and Breen, Bill: The Future of Management' published in 2007 by Harvard Business School Press

Drucker, P. F.: Preface to a new edition of "Innovation and Entrepreneurship" first published in 1985, available from http://www.managementlab.org/

Sawney, Wolcott and Arroniz published in Spring 2006 Vol. 47 No. 3 of the MIT Sloan Management Review entitled "The 12 different ways for companies to innovate”.
Sitra, 2008 Finland: http://www.sitra.fi/en/News/ articles/ Article_2008-01-22.htm

Newsletter of the MEC Analytical Group, 17 May 2009, China and the Middle East market

Simpfendorfr, Ben: "The New Silk Road: How a rising Arab world is turning away from the west and rediscovering China”, published by Palgrave Macmillan in 2009.

Collins, Daryl, Jonathan Morduch, Stuart Rutherford and Orlanda Ruthven, published in 2009 by Princeton University Press

Yunus, Mohamed: "Banker to the Poor : Micro-Lending and the Battle Against World Poverty" s, the founder of Grameen Bank and inventor of microfinance, published in revised and updated form in 2003 by Public Affair.

“The Bottom Billion - why the poorest countries are failing and what can be done about it” by Paul Collier, published in 2008 by Oxford University Press.

Novogratz, Jacqueline: "The Blue Sweater - bridging the gap between rich and poor in an interconnected world” by published in 2009 by Rodale

Moyo, Dambisa: Dead Aid - why aid is not working and how there is another way for Africa” published in 2009 by Penguin Books.

http://www.nordicinnovation.net/prosje kt.cfm?id=3-4415-291

Prahalad, C. K: "The Fortune at the Bottom of the Pyramid: Eradicating Poverty Through Profits” by, published in 2006 by Wharton School Publishing Paperbacks.

www.wri.org 
The Next 4 Billion - market size and business strategy at the base of the pyramid' is available for free online at www.wri.org.

http://www.sidw.org/event/2007/unlimit ed-potential-connecting-the-next-fivebillion

World Competitiveness Report 2008-2009: World Economic Forum

Hill, T. Christopher: "The post-scientific Society”, Christopher T. Hill, www.issues.org:80/24.1/c_hill http://www.rinovations.org/home http://www.positivedeviance.org/ http://www.changemakers.net/en-us/ competitions http://www.ashoka.org http://www.pg.com/en_US/index.shtml http://www.pg.com/b2b/pg_external.sht $\mathrm{ml}$

https://www.pgconnectdevelop.com/pgconnection-portal/ctx/noauth/

PortalHome.do https://www.pgconnectdevelop.com/ pg-connection portal/ctx/noauth/ 0_0_1_4_83_4_10.do

http://www.mrcleancarwash.com/about us.html http://www.pg.com/b2b/pg_tremor.shtml http://walmartstores.com/Sustainability/ http://www.intel.com/cd/software/partn er/asmo-na/eng/index.htm http://www.oecd.org/dataoecd/10/33/ 2090561.pdf http://www.worldagforum.org

\section{References related to the "Climate" chapter, in chronological order http://www.hm-treasury.gov.uk/ sternreview_index.htm}

\author{
http://www.ipcc.ch/ \\ http://www.cicero.uio.no \\ http://www.cowi.com/menu/news/ \\ newsarchive/nature/Pages/ \\ thenordicregionwillfeeltheheat.aspx \\ David Chandler, MIT News Office 19 \\ May 2009 http://web.mit.edu/ \\ newsoffice/2009/roulette-0519.html \\ The European Database for Global \\ Atmospheric Research at http:// \\ edgar.jrc.ec.europa.eu \\ http://www.occ.gov.uk/ \\ www.ipcc.ch ... International Panel on \\ Climate Change \\ http://unfccc.int/2860.php \\ See The Council on Competitiveness, \\ Energy Security, Innovation \& \\ Sustainability Initiative and Harvard \\ Business Review, "Forethought: \\ Climate Business, Business Climate,” \\ October, 2007.
}

\author{
See The Council on Competitiveness, \\ Energy Security, Innovation \& \\ Sustainability Initiative and Harvard \\ Business Review, "Forethought: Clima- \\ te Business, Business Climate,” Oc- \\ tober, 2007. \\ http://ec.europa.eu/energy/technology/ \\ set_plan/set_plan_en.htm \\ The EU-ETS http://ec.europa.eu/ \\ environment/climat/emission/ \\ index_en.htm \\ http://en.cop15.dk/ \\ In a conversation with David Cooperridge \\ in 2003 reported in the article available \\ at http://www.aacsb.edu/ \\ publications/Archives/JulAug08/ \\ 32-39\%20Sustainable\%20 \\ Innovation.pdf \\ http://www.nordicenergy.net/ \\ section.cfm?id=3-0\&path $=142$
}


Reducing U.S. Greenhouse Gas Emissions: How Much at What Cost? conducted by McKinsey \& Company and published jointly with the Conference Board in November, 2007, available at: http:// www.mckinsey.com/clientservice/ ccsi/greenhousegas.asp

http://www.nordicenergysolutions.org/ http://www.sunedison.com http://www.betterplace.com/ http://www.clintonfoundation.org/whatwe-do/clinton-climate-initiative/ http://www.c40cities.org/ http://www.kk.dk/sitecore/content/ Subsites/Klima/SubsiteFrontpage/ HvadGoerKoebenhavnsKommune/ KoebenhavnsKommunesklimaplan. aspx

http://www.toronto.ca/changeisintheair/ http://www.futuremelbourne.com.au/ wiki/view/ FMPlan/S2G3P1ZeroCarbonCity http://www.fastcompany.com/cities/ 2009

http://www.fastcompany.com/magazine/ 135/fast-cities-malmo-sweden.html http://www.fastcompany.com/magazin e/135/fast-cities-taipei-taiwan.html http://www.unep.org/pdf/

BioseqRRA_scr.pdf http://www.regjeringen.no/templates/Te ma.aspx id $=548491$ \&epslanguage $=\mathrm{E}$ N-GB

http://www.un-redd.org/ http://go.worldbank.org/9IGUMTMED0 http://www.gefweb.org/default.aspx http://www.climatechange.gov.au /index.html

EWP179 "Mitigating Climate Change Through Food and Land Use”, www.worldwatch.org

http://www.climatechange.gov.au/ncas /index.html

http://www.climatechange.gov.au/ inventory/index.html

http://www.ipcc.ch/ipccreports/ tp-climate-change-water.htm www.aberdeen.com

A review of green logistics schemes used in cities around the world" by Nikolas Geroliminis and Carlos F. Daganzo of Department of Civil and Environmental Engineering, Institute of Transportation Studies, University of California, 416 McLaughlin Hall, Berkeley, CA 94720, USA

http://www.metrans.org/nuf/documents/ geroliminis.pdf

http://ec.europa.eu/transport/marcopolo/ home/home_en.htm

Based on an article entitled "Testing metal” from the 29th Sep 2008 edition of the Economist.

McKinesy "How IT can cut emissions”, http:/www.mckinseyquarterly.com/ PDFDownload.aspx?ar=2221

http://www.reuters.com/article/GCABusinessofGreen/ idUSTRE52N2AX20090324

http://walmartstores.com/Sustainability/7 951.aspx

http://walmartstores.com/sites/ sustainabilityreport/2009/ en_threeKeyGoals.html www.EcosystemMarketplace.com www.cleantechcluster.fi/en www.nordiccleantech.net Go to http://www.eccj.or.jp/ index_e.html to find out more about the programme and download the report at http://www.aid-ee.org/ documents/018TopRunner-Japan. PDF for an evaluation.

http://ec.europa.eu/invest-in-research/ action/2006_ahogroup_en.htm

http://ec.europa.eu/enterprise/leadmarket/ leadmarket.htm

“The Venturesome Economy - How innovation sustains prosperity in a more connected world" published in 2008 by Princeton University Press, ISBN-13 978-0-691-13517-5. 
www.sustainablelifemedia.com/conten t/story/strategy/top_ten_reasons_wh y_new_green_products_fail http://www.peri.umass.edu/fileadmin/ pdf/other_publication_types/Green_ Jobs_PERI.pdf

Report 2001:05 by Torvanger and Asbjørn. http://www.cicero.uio.no/ media/1690.pdf
Report 2003:02, “Pro-Poor Climate Adaptation: Norwegian development cooperation and climate change adaptation - an assessment of issues, strategies and potential entry points” by Eriksen, Siri and Lars Otto Næss http:// www.cicero.uio.no/media/2465.pdf http://www.nordicinnovation.net/ article.cfm?id=1-834-804

Nordic Environmental Technology Solutions 


\section{Icelandic Summary}

\section{Samantekt}

Svæði, bjóðir og fyrirtæki sem á annað borð geta tekið breytingum og aðlagast nýjum aðstæðum munu með tímanum eiga mestu möguleikana á að viðhalda heilbrigðu jafnvægi milli vaxtar og velferðar innan samfélagasinna.

Pað er engan veginn fastákveðið frá náttúrunnar hendi að Norðurlöndin séu meðal efnuðustu landa heims.

En Norðurlöndin hafa sýnt pað, sérstaklega frá peim tímamótum sem urðu með iðnbyltingunni og nútímanum, að pau eru fær um að viðhalda stöðugri próun og endurnýjun.

Samstarf milli atvinnulífsins, stjórnvalda, háskólanna og samfélagsins er einn peirra pátta sem eru einkennandi fyrir próunina á Norðurlöndunum hvað varðar pennan árangur.

Norrænt samstarf er í pessum skilningi eðlilegur páttur í hinni norrænu próunaraðferð.

Árið 2005 mótaði Norræna ráðherranefndin sameiginlega norræna stefnu um nýsköpun, með pað að markmiði að styrkja nýsköpun í hverju Norðurlandanna sem og á svæðinu í heild, p. á m. í Eystrasaltslöndunum og einnig á nálægum svæðum.

Ísland hefur með formennsku sinni sett í forgang að meta pann árangur sem náðst hefur á síðustu 4-5 árum í norrænu nýsköpunarstefnunni sem eitt framtaksverkefna sinna á stjórnarmennskuári sínu 2009. Auk pessa ætti matið að innihalda nokkra kafla sem fjalla um langtímapróun í pví sem virðist líklegt til að móta norræna og alpjóðlega nýsköpunaráætlun.

Matið á norrænni nýsköpunarstefnu síðustu 5 ára leiðir í ljós að mikið hefur áunnist á sviði rekstrar. Æ fleiri norrænar nýsköpunarstofnanir eiga samvinnu á sviði nýsköpunarverkefna og í nokkrum tilvikum hefur slíkri 
samvinnu verið komið á fót í tengslum við rammaáætlanir Evrópusambandsins.

Lykilstofnunin sem knýr pessa gerð samvinnu áfram á vettvangi norrænna ríkja hefur verið Norræna nýsköpunarmiðstöðin.

Með pví að skoða hnattræna stöðu Norðurlandanna á sviði nokkurra valinna kennistærða í nýsköpun, eins og aðgangs að áhættufjármagni og nýsköpunar í heildi, fyrir árin 2005 og 2009, sést að Norðurlöndunum í heild hefur tekist að halda sig á meðal peirra landa sem hafa sýnt besta árangurinn í Mati á norrcenni stefnu um nýsköpun 2005-2009 og hnattræenni langtímapróun í heiminum.

Engu að síður hafa einnig stundum komið afturkippir. Til dæmis sýnir nýleg rannsókn, Nordic Innovation Monitor, að Norðurlöndin eru veik á sviði frumkvöðla, sem er mikið forgangsmál samkvæmt norrænu nýsköpunarstefnunni.

Á pví stigi nýsköpunarstefnu par sem fjallað er um stefnumörkun og stefnutækni hefur markmið norræns samstarfs verið að koma á fót aukinni samvinnu milli landa varðandi fjármögnun nýsköpunar og áætlana innan norræns rammasamstarfs, og til að skapa norrænt rannsóknar- og nýsköpunarsvæði (NORIA) sem yrði norræn hliðstæða við evrópska rannsóknarsvæðið (ERA).

Bókfræðimælingar á helstu hvítbókum norrænna ríkisstjórna um nýsköpun sýna að hugmyndin um NORIA hefur haft minni áhrif en búist var við árið 2005.

Detta vekur spurningu um hvort betra væri að koma á fót sjálfstæðu norrænu nýsköpunarsvæði (NIA) í framtíðinni í stað pess að sameina rannsóknir og nýsköpun undir einn hatt.

Sterkar og sjálfstæðar einingar bæði á sviði rannsókna og nýsköpunar með samstarfi gæti reynst sterkari hugmynd í reynd.

próun aukins samruna milli hinna innlendu nýsköpunarkerfa á Norðurlöndunum í sambyggt og samfellt norrænt nýsköpunarkerfi hefur verið annað markmið norrænu nýsköpunarstefnunnar.

Á grundvelli matsins er erfitt að draga skýrar ályktanir um pann árangur sem náðst hefur varðandi petta markmið. Annars vegar, ef litið er svo á að mælikvarði árangurs sé einhvers konar stofnanavæddur rammi fyrir samræmingu meðal lykilaðila innan norrænna nýsköpunarkerfa, hefur ekki tekist að ná markmiðinu sem slíku. 
Á hinn bóginn kann vel að hafa verið aukin óformleg samræming og að skipst hafi verið á stefnumálum og áætlunum, og stofnunsameiginlegra norrænna viðmiðunarhópa vegna rannsókna eins og „Global Nordic Innovation Monitor“ og „Nordic Innovation Monitor“ er vísbending um samræmingu og próun norrænna sjónarmiða að einhverju leyti.

Samt mun sennilega ávallt reynast óápreifanlegra að meta og mæla markmið eins og kerfi og samruna stefnu en t.d. próun hópa í kringum ákveðna tækni eða iðngrein.

Dess vegna er lagt til að norræn nýsköpunarstefna til framtíðar taki tillit til framangreinds óápreifanleika við mótun næstu kynslóðar norrænu nýsköpunarstefnunnar.

Starf Norrænu ráðherranefndarinnar varðandi nýsköpun nær einnig til Eistlands, Lettlands, Litháen og Sankti Pétursborgar, sem öll eru með norrænar skrifstofur og eru nefnd sem svæðisbundnir samstarfsaðilar á sviði nýsköpunar.

Matið og könnunin sýna að norræn nýsköpunarstefna nýtur almennt mikillar viðurkenningar og hún gegnir ákveðnu hlutverki í innlendri nýsköpunarstefnu Eystrasaltslanda

Samt sem áđur eru einnig athugasemdir par sem pví er lýst yfir að norrænar yfirlýsingar og samningar varðandi samstarf purfi á frekari aðgerðum að halda til pess að skipta máli í raun.

Önnur almenn niðurstaða sem fram kemur í matinu er hið hlutfallslega mikla hlutverk ríkisvaldsins og háskóla innan norræna nýsköpunarsamstarfsins og hið tiltölulega litla hlutverk atvinnulífsins.

Auk pess sem pað var nefnt í einhverjum athugasemdum með könnuninni endurspeglast petta á sviði stofnana pegar haft er í huga að af 34 meðlimum stjórna Norrænu nýsköpunarmiðstöðvarinnar, Norrænna rannsókna og Norrænna orkurannsókna eru eingöngu tveir úr atvinnulífinu. Samsetning pessara stjórna er eitt svið par sem norræn nýsköpunarog rannsóknarstefna mætti koma á auknu jafnvægi milli atvinnulífsins, stjórnvalda, háskólanna og atvinnulífsins.

Síðari hluti matsins beinist að langtímapróun, sem er líklegt að hafi áhrif á næstu kynslóð norrænnar nýsköpunarstefnu. Með tilliti til umfjöllunarefnis fjalla kaflarnir um hugmyndir varðandi: 
- Umbreytinguna í átt til sjálfbærs hagkerfis

- Ný og upprennandi líkön hnattvæðingar

- Virðiskeðju sem nýsköpunarkerfi

- Hlutverk skipulags og stjórnunar

- Mælingu og stjórnun nýsköpunar

- Rugling milli rannsókna og nýsköpunar

Án pess að fara ofan í smáatriði varðandi efni hvers kafla í pessari samantekt pá snerta kaflarnir frumkvæði bað sem Norræna ráðherranefndin hefur unnið að á sviði hnattvæðingar með ýmsum hætti og vísa til framtíðaráskorana og forgangsmála samkvæmt norrænu nýsköpunarstefnunni.

Norrænu hagkerfin hafa sýnt árangur, eins og minnst var á, varðandi pað að aðlagast breyttum aðstæðum og beita lausnum á sviði nýsköpunar á peirri vegferð. Til pess hins vegar að viðhalda pessari próun verða Norðurlöndin sennilega að vera leiðtogi en ekki sporgöngumaður á mörgum peim sviðum sem fjallað var um varðandi langtímapróun. Ýmis teikn eru á lofti um að petta sé að gerast, t.d. innan nýsköpunar í opinbera geiranum og á öðrum sviðum, eins og pví hvernig eigi að útfæra lausnir við að fá aðgang að upplýsingaveitum á sviði hnattrænnar nýsköpunar.

Engu að síður eru tvö vandamál sem einkum hafa breytt allri stöðu varðandi pað hvernig best má nálgast og ræða norrænar aðgerðir í framtíðinni. Vandamálin tvö eru hlýnun jarðar og alpjóðlega fjármálahrunið. Alpjóðlega fjármálahrunið hefur sýnt okkur að efnahagsstefna síðustu 25 ára hefur brugðist illa. Í stuttu máli hafa Vesturlönd og Norðurlöndin par á meðal lifað um efni fram. Sennileg niðurstaða alls pessa er að við munum purfa að endurmeta hlutverk okkar í hinu hnattræna hagkerfi, hvernig við fáum aðgang að auðlindum og ekki síst hvernig við notum pessar auðlindir.

Hlýnun jarðar er síðara vandamálið. Hægt er að líta á hana bæði sem tækifæri og sem hömlur. Hægt er að skoða hana sem tækifæri í peim skilningi að Norðurlöndin eru með traustan grundvöll fyrir próun og uppbyggingu nýrra lausna og starfa innan núverandi og upprennandi sviða er snerta orku og umhverfi. En til pess að geta náð árangri purfa Norðurlöndin sennilega að endurmeta núverandi vaxtarlíkan og pví næst skilning okkar á nýsköpun. Fráhvarf frá hagkerfi sem byggist á jarðefnaeldsneyti að umhverfislega sjálfbæru hagkerfi krefst pess að beitt sé nýjum gerðum skipulagningar, nýjum leiðum til samstarfs við aðra hluta heimsins, 
nýjum hvötum fyrir frumkvöðla og nýjum aðferðum á sviði markaðsaðkomu ríkja.

Í raun er hugmyndin um nýsköpunarhagkerfi hugsanlega úrelt og nærtækara og meira viðeigandi hugtak gæti verið viskuhagkerfið. Hagkerfi sem ekki er eingöngu byggt á vaxtarformúlunni sem ríkti á iðnaðartímabilinu og núverandi tímabili heldur frekar umræða sem byggist á pví hvernig við mælum gæði með öðrum mælikvörðum en fjárhagsávinningi og innan peirra ramma sem hlýnun jarðar og fjárhagslegar takmarkanir setja okkur. 



\section{Sammanfattning}

Regioner, nasjoner og selskaper som er i stand til å endre seg og tilpasse seg nye betingelser, vil over tid ha størst sjanser til å opprettholde en sunn balanse mellom vekst og økonomisk fremgang i samfunnene de er en del av. Man kan på ingen måte ta for gitt at de nordiske landene kommer til å være blant verdens rikeste samfunn. Helt fra begynnelsen av den industrielle og moderne tidsalder har imidlertid de nordiske landene vist seg å være særlig godt i stand til å utvikle seg og fornye seg fortløpende. Samarbeid mellom industri, regjering, akademia og samfunnet som helhet har vært et av kjennetegnene ved de nordiske landenes utvikling på disse områdene. I så måte er nordisk samarbeid en naturlig bestanddel i den nordiske tilnærmingen til utvikling.

I 2005 formulerte Nordisk Ministerråd en felles nordisk innovasjonspolitikk. Målet var å konsolidere innovasjonen innen hvert av de nordiske landene og i regionen som helhet, deriblant de baltiske landene og naboregionene. Det islandske formannskapets og denne publikasjonens intensjon er å peke på sannsynlige fremtidige utviklingstendenser som vil sette sitt preg på diskusjonen om innovasjon samt å øve innflytelse på de nordiske landenes innovasjonspolitikk og prioriteringer.

Denne publikasjonen fokuserer på fremtidige utviklingstendenser som trolig vil ha betydning for neste generasjons innovasjonspolitikk i Norden. Tematisk omhandler kapitlene følgende konsepter:

- Overgang til en bærekraftig økonomi

- Nye og kommende modeller for globalisering

- Verdikjeden som innovasjonssystem 
- Betydningen av organisering og ledelse

- Måling og styring av innovasjon

- Sammenblanding av forskning og innovasjon

- Styrking av kjerneområder for global innovasjon

Uten å gå i detalj om innholdet i hvert kapittel i dette sammendraget kan man slå fast at disse konseptene på flere måter har betydning for Nordisk Ministerråds globaliseringsinitiativer. De retter også søkelyset mot fremtidige utfordringer knyttet til nordisk innovasjonspolitikk. Som nevnt over har de nordiske økonomiene historisk sett lyktes godt med å tilpasse seg skiftende betingelser og med å ta i bruk innovative løsninger. For å opprettholde denne utviklingen må imidlertid de nordiske landene sannsynligvis innta en ledende rolle og ikke bare være passiv deltaker innenfor mange av områdene som diskuteres under de fremtidige utviklingstendensene. Det kan synes som om dette allerede er i ferd med å skje. Det gjelder blant annet innovasjon i offentlig sektor samt andre områder, som utvikling av løsninger for å dra nytte av kjerneområdene for global innovasjon.

Imidlertid er det særlig to forhold som har endret måten vi best kan tilnærme oss og drøfte de nordiske landenes fremtidige rolle på: global oppvarming og den globale finanskrisen. Den globale finanskrisen har vist oss at de siste 25 årenes økonomiske politikk har mislyktes på flere viktige områder. Et mulig resultat er at vi må tenke nytt om vår rolle i den globale økonomien, revurdere ressurstilgangen og ikke minst hvordan vi nyttiggjør oss disse ressursene. Det andre punktet er global oppvarming. Den kan både betraktes som en mulighet og en begrensning. Den kan betraktes som en mulighet $\mathrm{i}$ den forstand at den nordiske regionen har en sterk plattform for utvikling av nye løsninger og arbeidsplasser innenfor eksisterende og fremvoksende områder knyttet til energi og miljø. For å lykkes må den nordiske regionen sannsynligvis revurdere sentrale punkter $\mathrm{i}$ den eksisterende vekstmodellen - også vårt syn på innovasjon. Overgangen fra en økonomi som er basert på fossilt brensel til en økonomi som er miljømessig bærekraftig, vil kreve nye organisasjonsformer, nye metoder for globalt samarbeid, nye incentiver for privat utvikling og nye metoder for interaksjon mellom stat og marked. 
Faktisk er det mulig at forestillingen om en innovasjonsøkonomi allerede er foreldet. Et mer passende begrep kan være «kunnskapsøkonomi». Det er en økonomi som ikke bare er basert på vekstparadigmet i den industrielle og moderne tidsalder, men snarere på en debatt om hvordan man kan måle kvalitet med andre midler enn finansiell profitt, innenfor rammen av global oppvarming og finansielle begrensninger. 